Portland State University

PDXScholar

Spring 7-23-2013

\title{
Macroeconomic and Political Determinants of Foreign Direct Investment in the Middle East
}

Robin Barnaby Calver

Portland State University

Follow this and additional works at: https://pdxscholar.library.pdx.edu/open_access_etds

Part of the Econometrics Commons, Macroeconomics Commons, and the Other Political Science Commons

Let us know how access to this document benefits you.

\section{Recommended Citation}

Calver, Robin Barnaby, "Macroeconomic and Political Determinants of Foreign Direct Investment in the Middle East" (2013). Dissertations and Theses. Paper 1074.

https://doi.org/10.15760/etd.1074

This Thesis is brought to you for free and open access. It has been accepted for inclusion in Dissertations and Theses by an authorized administrator of PDXScholar. Please contact us if we can make this document more accessible: pdxscholar@pdx.edu. 
Macroeconomic and Political Determinants of Foreign Direct Investment in the Middle East

by

Robin Barnaby Calver

A thesis submitted in partial fulfillment of the requirements for the degree of

\author{
Master of Arts \\ in \\ Political Science
}

Thesis Committee:

Birol Yesilada, Chair

Ronald Tammen

Melody Valdini

Portland State University

2013 
(C) 2013 Robin Barnaby Calver 


\begin{abstract}
This study argues that governments with sustained GDP growth, open markets, low country risk, high levels and low standard deviation of government performance, and few or no occurrences of war, will see larger levels of foreign direct investment (FDI) over time. Scholarship on the determinants of FDI variously argues the influence of GDP growth, the openness of a country's economy, a government's level of political capacity, the level of country risk, and the negative effects of inter-, intra- and extrastate conflict. These studies on the various effects on FDI, while providing insightful and substantial statistical results, fail to capture the simultaneous effects of macroeconomic, government performance, country risk, and war variables. The present study attempts to resolve this gap in the literature on FDI by proposing a multi-dimensional model of the combined effects of un-weighted macroeconomic, political, country risk, and war variables on FDI flows over time. The empirical results confirm the expected multi-dimensional nature of FDI flows over time and provide insight into the macroeconomic and political effects on regional and country-level yearly flows of FDI, as well as yielding some unexpected and counter-intuitive results of the role war plays on FDI flows over time.
\end{abstract}




\section{Dedication}

This study is dedicated to my grandparents James and Dorothy Calver, and Herbert and Agnes Worsdall.

To my parents David and Deirdre Calver and my brother Duncan Calver.

To my wife Rachael Roberts.

A special dedication to my friends, past and present, Bill, Bodger, Suki, Dizzy and Lizzy, Edie and Jenny, Pete, Sophie, Abby Bean, Mimi, Bubbles McBindle, and Sir Ferro Winston Busby. 


\section{Acknowledgments}

I'd like to thank the members of my thesis committee for their expertise and guidance:

Dr. Ronald Tammen, Hatfield School of Government, Portland State University, Dr. Melody Valdini, Hatfield School of Government, Portland State University, and Dr. Birol

Yeşilada, Hatfield School of Government, Portland State University. A special thank you to Dr. Robert Fountain, Fariborz Maseeh Department of Mathematics and Statistics, Portland State University, for his advice and recommendations regarding the statistical analysis methods used in this study. 


\section{Table of Contents}

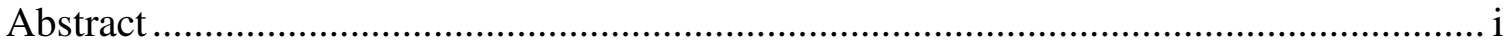

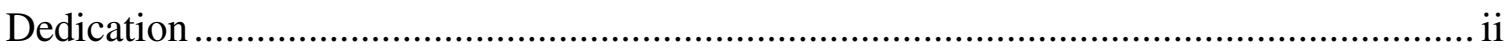

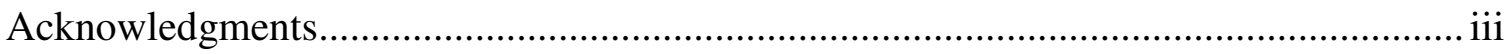

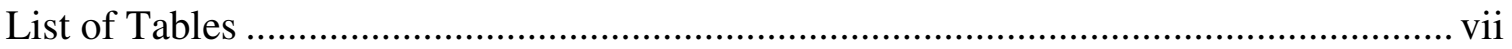

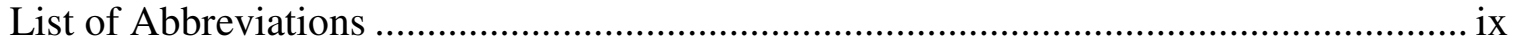

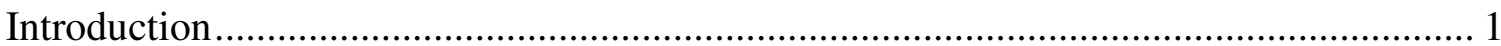

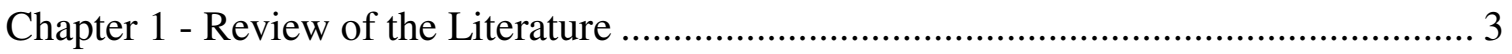

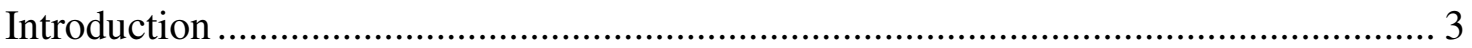

Macroeconomic Factors of FDI Flows: GDP Growth and Openness of Economy ........ 5

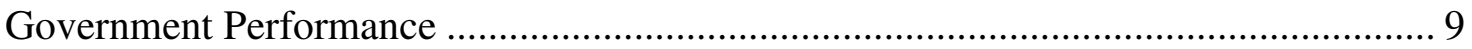

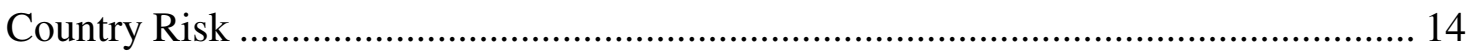

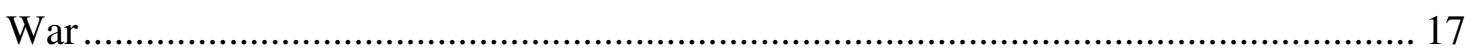

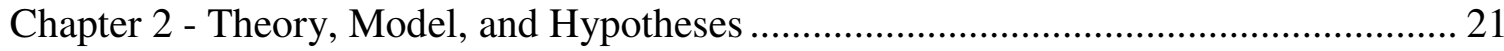

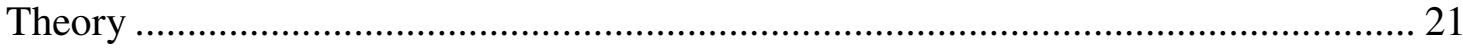

Model, Methodology and Statistical Technique Used .......................................... 22

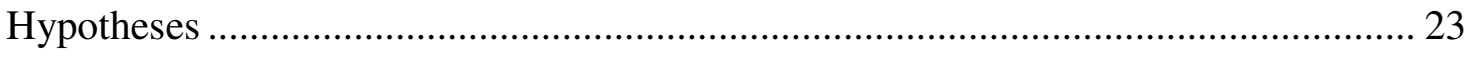

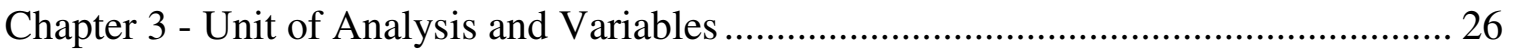

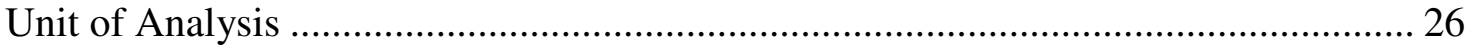




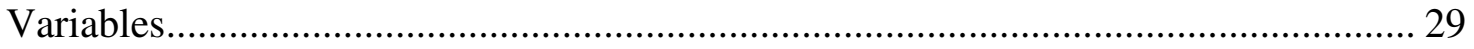

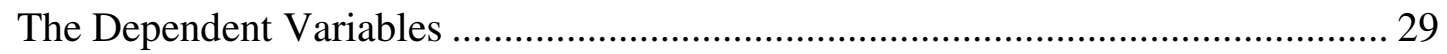

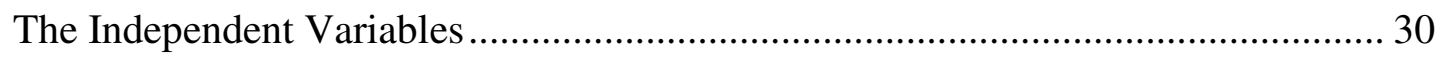

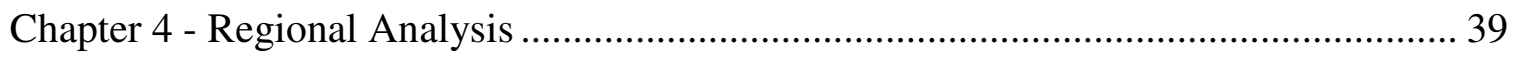

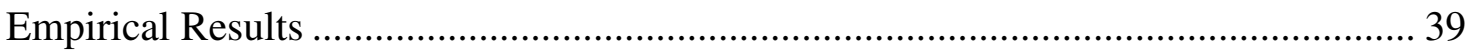

Chapter 5 - Country Level Analysis ........................................................................... 49

Introduction to Country Level Analysis ................................................................. 49

Turkey Sub-Analysis: Greatest Net Change in Foreign Direct Investment ................... 51

Saudi Arabia Sub-Analysis: Greatest Net Change in GDP Growth............................... 54

Iraq Sub-Analysis: Highest Net Change in Openness, Highest Level of Country Risk, and Most Occurrences of Extrastate War................................................................ 58

Israel Sub-Analysis: Highest Median Government Performance with the Lowest

Standard Deviation of Government Performance ……................................................... 63

United Arab Emirates Sub-Analysis: Lowest Level of Country Risk ........................... 66

Pakistan Sub-Analysis: Most Incidents of Intrastate War............................................ 69

Bahrain Sub-Analysis: Petroleum Dependent Country................................................. 72

Iran Sub-Analysis: Country of General Interest.......................................................... 76

Chapter 6 - Overall Conclusions and Limitations of the Model Presented ....................... 80

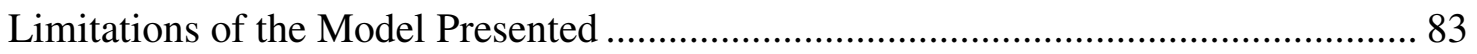




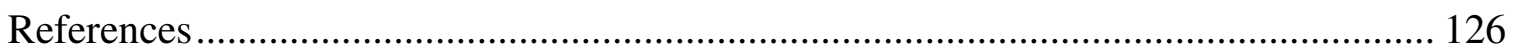




\section{List of Tables}

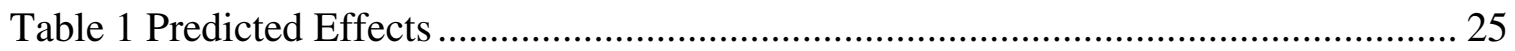

Table 2 Regional Analysis Coefficients ...................................................................... 87

Table 3 Regional Analysis Pearson Correlation Coefficients.......................................... 88

Table 4 Turkey Analysis Coefficients ................................................................... 89

Table 5 Turkey Analysis Pearson Correlation Coefficients ............................................ 90

Table 6 Region vs. Turkey Pearson Correlation Coefficients Comparison....................... 91

Table 7 Region vs. Turkey Selected Model Predictors Comparison ................................... 92

Table 8 Saudi Arabia Analysis Coefficients .................................................................. 93

Table 9 Saudi Arabia Analysis Pearson Correlation Coefficients ..................................... 94

Table 10 Region vs. Saudi Arabia Pearson Correlation Coefficients Comparison .......... 95

Table 11 Region vs. Saudi Arabia Selected Model Predictors Comparison....................... 96

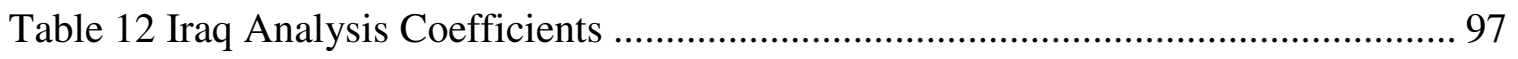

Table 13 Iraq Analysis Pearson Correlation Coefficients................................................... 98

Table 14 Region vs. Iraq Pearson Correlation Coefficients Comparison .......................... 99

Table 15 Region vs. Iraq Selected Model Predictors Comparison ................................. 100

Table 16 Israel Analysis Coefficients ............................................................................... 101

Table 17 Israel Analysis Pearson Correlation Coefficients ............................................. 102

Table 18 Region vs. Israel Pearson Correlation Coefficients Comparison ..................... 103

Table 19 Region vs. Israel Selected Model Predictors Comparison................................. 104

Table 20 United Arab Emirates Analysis Coefficients.................................................. 105

Table 21 United Arab Emirates Analysis Pearson Correlation Coefficients .................. 106 
Table 22 Region vs. United Arab Emirates Pearson Correlation Coefficients Comparison 107

Table 23 Region vs. United Arab Emirates Selected Model Predictors Comparison .... 108

Table 24 Pakistan Analysis Coefficients ............................................................... 109

Table 25 Pakistan Analysis Pearson Correlation Coefficients ................................... 110

Table 26 Region vs. Pakistan Pearson Correlation Coefficients Comparison................ 111

Table 27 Region vs. Pakistan Selected Model Predictors Comparison ......................... 112

Table 28 Bahrain Analysis Coefficients ................................................................ 113

Table 29 Bahrain Analysis Pearson Correlation Coefficients .................................... 114

Table 30 Region vs. Bahrain Pearson Correlation Coefficients Comparison................ 115

Table 31 Region vs. Bahrain Selected Model Predictors Comparison.......................... 116

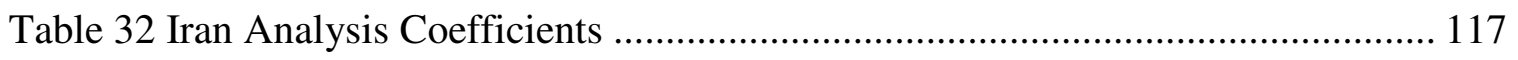

Table 33 Iran Analysis Pearson Correlation Coefficients......................................... 118

Table 34 Region vs. Iran Pearson Correlation Coefficients Comparison ...................... 119

Table 35 Region vs. Iran Selected Model Predictors Comparison ............................... 120

Table 36 Region vs. All Country Sub-Analyses Pearson Correlation Coefficients

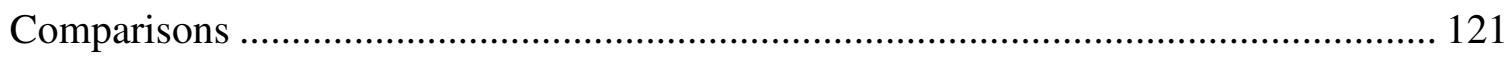

Table 37 Region vs. All Country Sub-Analyses Selected Model Predictors Comparisons

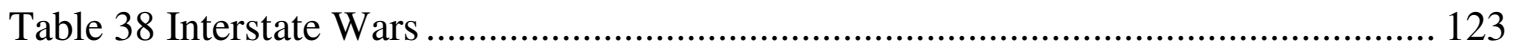

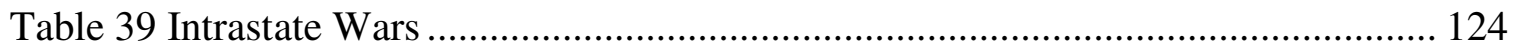

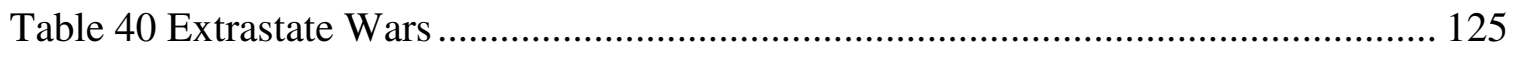




\section{List of Abbreviations}

FDI $=$ Foreign Direct Investment

$\mathrm{MNC}=$ Multinational Corporation

$\mathrm{RPE}=$ Relative Political Extraction 


\section{Introduction}

This study asks the question, what are the movers of yearly flows of Foreign Direct Investment (FDI) over time in a given region or country? This study proposes and assesses the theory that over time FDI in the Middle East is moved by not one but a combination of macroeconomic, government performance, country risk, and conflict factors. This study makes a national level, time series (1993 - 2007) comparison of fourteen countries in the Middle East. These countries are: Bahrain, Egypt, Iran, Iraq, Israel, Jordan, Kuwait, Oman, Pakistan, Qatar, Saudi Arabia, Syria, Turkey, and the United Arab Emirates. While Afghanistan, in the popular imagination and in scholarship, is often considered to be part of the Middle East, the lack of data on FDI flows renders it presently untenable as a subject of analysis. This is an important question for the following reasons, among others. First, investors seeking to either expand existing or new markets are confronted with many indicators as to the feasibility and suitability of an environment for investing and a set of useful and replicable indicators can aid in these endeavors. Second, increased or sustained flows of FDI, when combined with dyadic analyses, can indicate the stability of interstate political relationships. Third, developing or expanding economies tend to look to foreign investment to supplement domestic efforts in spurring new sector infrastructure development and market development. Therefore, a set of indicators that foreign directors may be considering is useful in informing the domestic and foreign policies of target countries.

Numerous empirical studies have theorized and demonstrated that investors place their money in countries that demonstrate economic growth or growth potential, have 
policies conducive to capital flows, have effective governance, stable investment environments, and that lack war and conflict. The results of this study's analysis may indicate the following about political economy. First, macroeconomic phenomena may be moved by a variety of non-macroeconomic variables. Second, market feasibility may not necessarily be hampered by conflict. Last, an aggregate of factors may be a useful set of starting points in order to address country-level FDI potential from a comparativist perspective.

This study tests and evaluates various theories in the literature that have tried to determine what variable or variables are moving FDI flows in both developed and developing countries, particularly in the Middle East. This study contributes to the literature by testing the extent, if any, to which macroeconomic, government performance, country risk, and war factors move FDI flows over time at the regional and country level. 


\section{Chapter 1 - Review of the Literature}

\section{$\underline{\text { Introduction }}$}

It is advantageous for a multinational corporation to be an early entrant in an emerging market. Early entry provides market power which yields monopolistic profits resulting from new sources of demand, acquisition of cheaper raw materials, and economies of scale (McGowan Jr and Moeller 2009, 28). Thus, a model to shed light on the movers of FDI is advantageous to private businesses and governments wishing to create business ties or establish or increase interdependence. For example, FDI brings with it not just capital that would be difficult to generate through domestic savings, but also the transfer of up-to-date technologies (Lipsey 2007). Thus, FDI and transfer of capital can bring with them economic growth and development. For example, Klasra (2011) states that FDI affects economic growth through various venues like increasing capital formation, advanced technology and know-how, employment and possible spillover effects on local firms. Many studies have tried to quantify FDI's contribution to economic growth and have come up with mixed results (Klasra 2011, 224).

FDI can alter the dynamics of a country's trade and comparative advantage. By altering a country's comparative advantages and improving its competitiveness through technology transfer and the effects of myriad externalities, foreign as well as domestic investment can alter a country's volume and pattern of trade in many income-enhancing directions (Lipsey 2007). Income enhancement can be beneficial for infrastructure, human growth, and political growth. Like any other region, the Middle Eastern 
countries are looking to investors outside their countries to increase their economic development. FDI plays a significant role in the development of international trade, and it helps to establish direct, stable, and long-lasting links between economies. The Organization for Economic Co-operation and Development (OECD) states that FDI can serve as an important vehicle for local enterprise development, strengthening the competitiveness of both the recipient and investor (Groh and Wich 2012, 211). For example, Turkey in particular is pursuing further political and monetary integration with Europe. In that case maintaining a government effectiveness that is conducive to foreign investment and increases comparative advantage is integral to its integrationist aspirations.

FDI demonstrates the ability of a government to allow and facilitate the influx of foreign capital to advance national or private-sector goals. It increases the extractive potential for the government because it provides an additional source of taxable funds. These funds can in turn be used to provide for infrastructure and other structural advances. Additionally, a country that has accumulated unsustainable debt may need new inflows of FDI to mobilize development finance (Onyeiwu and Shrestha 2004, 89).

Some studies suggest that certain macroeconomic conditions or host-country characteristics foster FDI interest. Tied to Dunning's (1981) ownership, location, and internationalization framework as well as Markusen's (1995) knowledge capital, and vertical and horizontal integration models that focused on firm-level decisions, macroeconomic conditions provide varying incentives for foreign investors. Positive macroeconomic conditions such as high domestic growth rates, rising per capita GDP, 
and larger markets indicate a promising domestic market (Biglaiser and DeRouen 2007, 837).

The literature on FDI determinants is generally divided into four categories: (a) macroeconomic and host-country conditions; (b) economic reforms; (c) level of democratization; and (d) follow the flag/security considerations. The present study divides the theories of the determinants of FDI into four categories: macroeconomic, government performance, country risk (economic climate), and war. The following review of the literature discusses and critiques these various approaches and argues why an aggregate of these categories is necessary to capture the full dynamic of FDI flows in the Middle East.

\section{Macroeconomic Factors of FDI Flows: GDP Growth and Openness of Economy}

The first macroeconomic variable this study assesses as accounting for variance in FDI flows over time is GDP Growth. Coan and Kugler (2008) have argued that economic growth is an indicator consistently included in empirical studies of FDI. The future potential of a nation's economy has direct effects not simply upon the level of capital available at any given point in time, but also on changes in the economic incentive structure of the population, on the type of FDI available, and on overall investment opportunities (Chen and Mohsin, 1997; Billington, 1999). More specifically, changes in growth can both attract new FDI and alter the dynamics of older FDI, as the incentive structures of the population change in relation to the changing levels of income.

Development leads not only leads to increased customer bases, but to more 
important shifts within industries in host economies, which may in time spur future FDI (Wheeler and Mody, 1992; (Coan and Kugler 2008, 404). Studies on FDI have found a positive relationship between economic growth and FDI (Chakrabarti 2001; Onyeiwu and Shrestha 2004). Apart from having large domestic markets, high-growth economies typically implement stable and credible macroeconomic policies that attract foreign investors (Onyeiwu and Shrestha 2004, 95).

The second macroeconomic variable this study assesses as accounting for variance in FDI flows over time is the Openness of a country's economy. This study draws on the literature that expresses the Openness of a country's economy as a quantitative expression of the volume of its imports and exports, and argues it is a qualitative expression of its policy on the extent of its economic flows to and from the country. As such, in the literature a country's economic openness is considered to be a mover of FDI flows.

Among the macroeconomic theories that speak to the positive effect of a region or country's Openness on FDI, Dunning (1998) argues that rent seeking, market seeking, efficiency seeking and strategic-asset are motivating factors of FDI inflows. More specifically, 'rent-seeking' motives involve foreign firms seeking cheaper factors of production and inputs of production such as primary goods. 'Market seeking' FDI motive involves foreign firms exporting or opening new markets in host countries in order to increase sales. This is an alternative for businesses to face trade restrictions like high transport costs and rules of origin. The 'efficiency seeking' companies want to use a small number of countries to serve larger markets. Some important factors in this motive 
are location, government regulation and endowments. Finally the 'strategic-asset' motive is related to maintaining foreign firms' international position and competitiveness (Liargovas and Skandalis 2012, 324).

Additional support for the use of Openness as a mover of FDI can be found in discussions on the ease of ingress and egress of liquidity and securities. The ease with which investors can move capital in and out of a country (the openness of the economy) is an important determinant of FDI flows (Chakrabarti 2001). Countries with capital controls and restrictive trade policies discourage inflows of FDI, compared to countries with liberal policies. Most of the studies on FDI in developing countries have identified a positive relationship between openness and FDI (Onyeiwu and Shrestha 2004, 95).

Open economies are more likely to implement and maintain stable and credible macroeconomic policies than autarkic regimes. Since stable macroeconomic policies (including low inflation rates) tend to reduce business risks, foreign investors are more prone to investing in open economies than in closed economies. Foreign investors can repatriate their earnings with relative ease in open economies, and the risk of arbitrary expropriation of assets is low in such economies. To that end, Onyeiwu and Shrestha argue that the incorporation of an Openness variable results in a positive effect on FDI, which is consistent with previous studies (Kravis and Lipsey 1982; Culem 1988; Edwards 1990; Asiedu 2002) (Onyeiwu and Shrestha 2004, 100).

Klasra argues there are several studies providing evidence about the positive effects of Openness of a country on its economic growth and exports. For example, Arslan and Wijnbergen (1993), Joshi and Little (1996) and other studies have found that 
trade liberalization in developing countries caused improvements in their economic performance (2011). The logic behind this outcome has been the exposition that trade liberalization reduces anti-export bias and makes exports more competitive in international markets. Some studies, however, show some skepticism regarding the link between openness and export performance (Greenaway and Sapsfor 1994; Jenkins 1996; Greenaway et al. 2002) (Klasra 2011, 224). The present study, however, is concerned with the movers of FDI and not the interrelationship of FDI and exports, or economic growth and exports. For example, Klasra used a slightly different methodology of annual time series data on foreign direct investment (FDI), gross domestic product (GDP), export, and trade openness from 1975 - 2004. Therefore, the presents study uses Openness as an indicator, both conceptual and quantitative, of the macroeconomic and political decision-making dynamics of a country and how they together under the rubric of Openness may influence or explain some of the variance of FDI over time. Similarly, in order to avoid any operational problems arising from endogeneity, the present study uses only one indicator of exports (in the Openness score) and not exports as an additional variable.

In operationalizing Openness Liargovas and Skandalis use exports divided by GDP, imports divided by GDP and total trade divided by GDP, among others $(2012,327$ 328). Using an econometric model they found a positive and significant relationship between FDI inflows and trade openness. They also found that there are some other factors such as political stability, exchange rate stability and market size (as expressed by 
GDP) with positive influence to the existence of FDI (Liargovas and Skandalis 2012, 329)

\section{Government Performance}

It is generally argued that governments that are effective or capable, regardless of how this is defined, are more amenable as venues for FDI and economic growth in general. Although a variety of measures have been advanced to measure political performance, there has been a lack of consensus over the best way to conceptualize it or what it is ultimately the dependent variable being measured. To place Government Performance at the door of being a function of regime type, economic power, military capabilities, or population is to simply re-name these variables (Kugler and Tammen 2012). Therefore, an indicator of Government Performance is useful in providing an investor with a quantitative means of assessing the effectiveness and stability of government policies. Follows is a discussion of the various theories of measuring Government Performance.

The World Bank has conceptualized capacity in "good governance" terms. "The Worldwide Governance Indicators (WGI) project reports aggregate and individual governance indicators for 213 economies over the period 1996-2010, for six dimensions of governance: Voice and accountability; political stability and absence of violence; government effectiveness; regulatory quality; rule of law; and, control of corruption. The aggregate indicators combine the views of a large number of enterprise, citizen and expert survey respondents in industrial and developing countries. The individual data 
sources underlying the aggregate indicators are drawn from a diverse variety of survey institutes, think tanks, non-governmental organizations, and international organizations" (Kaufmann, Kraay, and Mastruzzi 2011). To that end, the World Bank defines the Government Effectiveness indicator as "capturing perceptions of the quality of public services, the quality of the civil service and the degree of its independence from political pressures, the quality of policy formulation and implementation, and the credibility of the government's commitment to such policies" (Kaufmann, Kraay, and Mastruzzi 2011). Thus, the World Bank's indicators are qualitative, subjective and normative. For comparative purposes, the World Bank's method of determining Government Performance, which has no quantitative or objective measures, lacks utility and measurable variance.

The concept of political capacity advanced by Organski and Kugler (1981) and later built upon by Arbetman and Kugler (1997) has a large amount of comparative utility. The power transition program conceptualizes national capacity and political performance as a government's extractive capability of resources, in this case taxes (Arbetman-Rabinowitz and Johnson 2008; Arbetman and Kugler 1997; Kugler and Tammen 2012; Organski 1958; Organski and Kugler 1981; Tammen 2000). Government Performance, as defined by Kugler and Tammen, is measured in Extraction of resources from the populace (Kugler and Tammen 2012), resulting in the term Relative Political Extraction (RPE). RPE approximates the ability of governments to appropriate portions of the national output to advance public goals. Among public goals is the economic development of a country, and this is often advanced through the attraction of FDI. 
Generally, investors prefer a political environment that is stable, predictable and capable. Therefore, a state must have the political capacity to create an environment that will attract FDI. FDI demonstrates the ability of a government to allow and facilitate the influx of foreign capital to advance national goals. FDI increases the extractive potential for the government because it provides an additional source of taxable funds. These funds can in turn be used to provide for infrastructure and other structural advances.

The RPE measure of Government Effectiveness is particularly useful as a predictor of FDI flows and enjoys strong support in the literature. FDI is a useful indicator of economic development and government effectiveness because it demonstrates the willingness of governments to allow ingress and egress in its markets and the stability of those markets. RPE reflects the strength of the government of a country. The higher the RPE of a country, the stronger its government, and the more stable its expected future economic policy. Therefore, Government Effectiveness affects capital flows through its effect on economic policy (Adji, Ahn, and Holsey 1997, 130). Because a country with high political capacity is expected to have more stable economic policies than a country with low political capacity, foreign investors are expected to invest more in the country with high political capacity (Adji, Ahn, and Holsey 1997, 130). This consideration suggests that relative political capacity will be positively correlated with foreign private capital flows (Adji, Ahn, and Holsey 1997, 133).

Political uncertainty resulting from the variance of RPE adversely affects private investment, confirming numerous studies that show uncertainty causes a decrease in private investment (Grier and Tullock 1989; Rodrik 1991; Aizenman and Marion 1993). 
Thus, a high level of variability in political capacity increases macropolitical uncertainty, which in turn decreases private investment in the same way that macroeconomic uncertainty does. This suggests that a lack of consistency in a government's capacity to rule a nation or to organize the society will generate political uncertainty in the marketplace (Feng and Chen 1997).

LeBlang makes an explicit break with the prevalent convention in the political development field that economic and political progress go hand in hand $(1997,111)$. According to this view, if a nation possesses a large relative amount of wealth, then it will also be capable of performing efficiently in the political realm. This view is based on observations of the developmental history of the West. Countries in Western Europe, parts of North America, and Japan have industrialized and established efficient bureaucratic structures. The error in this approach is it does not permit the economic and political structures of a country to be analyzed separately. "... [A]s nations undergo the transition from preindustrial to industrial development, it is readily observable that the independence of the political and the economic sectors becomes more profound" (Leblang 1997, 111) In preindustrial societies a change in the social, economic, or political sector did not cause a change in the other sectors (Leblang 1997, 111 - 112). By contrast, in industrial societies even casual observation suggests that a change in the structure of the economy has direct consequences for the way in which political power is exercised, and vice-versa (Leblang 1997, 112).

LeBlang, however, does not isolate the relationship between FDI and RPE. He argues the nonlinear relationship between investment, capacity, and growth. Specifically, 
he states that the traditional expectation from the political science and economic literature is that a nation's level of socioeconomic development is linearly related to its level of political development. In explaining variations in economic growth, he breaks with tradition in two significant ways. First, it is posited that the effect of political capacity on a nation's growth rate depends on the level of wealth of the nation; that is, there is an interaction between political and economic development. Second, this interactive effect is not constant - the effect diminishes as a nation grows wealthier (Leblang 1997, 113).

The role of governance infrastructure has also been put forth as a determinant of attracting FDI and increasing FDI flows over time. For example, governance infrastructure has been defined as a country's political, institutional and legal environment (Globerman and Shapiro 2002). Globerman and Shapiro have shown that governance infrastructure is an important determinant of both FDI inflows and outflows. Investments in governance infrastructure not only attract capital, but also create the conditions under which domestic multinational corporations (MNCs) emerge and invest abroad. It would appear that investments in governance infrastructure are subject to diminishing returns, so that the benefits, in terms of inflows, are most pronounced for smaller and developing economies (Globerman and Shapiro 2002, 1899).

Globerman and Shapiro (2002) argue "positive" governance infrastructure would therefore include: an effective, impartial and transparent legal system that protects property and individual rights; public institutions that are stable, credible and honest; and government policies that favor free and open markets. These conditions encourage FDI, and presumably private domestic investment as well, by protecting privately held assets 
from arbitrary direct or indirect appropriation. In a related manner, the same conditions encourage sunk cost investments by MNCs that facilitate efficient operation in host countries (Globerman and Shapiro 2002, 1901).

\section{$\underline{\text { Country Risk }}$}

From 1993 to 2007, FDI in the Middle East increased by 3365 percent (World Bank 2012). This trend provides evidence for the need for multinational corporations to have access to a reliable model for predicting Country Risk as the risks of entering a new foreign market directly are not only higher than expanding investments in the domestic market where conditions are known and more predictable, but are also difficult to forecast. FDI arises when the host country has an investment opportunity that it cannot exploit by itself because it lacks the means or technical know-how, or because of market incompleteness (that is, access to capital markets is restricted). A MNC may be able to exploit such an opportunity because it has the necessary capital, technology, and managerial skills to do so.

Obtaining a reliable and accurate forecast of Country Risk is necessary for any multinational corporation (MNC) decision maker. Generally, Country Risk relates to the likelihood that changes in a foreign business environment will occur and will reduce the profitability or riskiness of an overseas FDI. The main components of Country Risk that investors need to consider are political risk and economic risk for a country. For example, political risk can refer to the risk that the politics within a country will affect a multinational's FDI in that country (McGowan Jr and Moeller 2009, 28). Lucas (1990) 
focuses on the political environment and components of Country Risk, and attributes a lack of FDI in countries with potentially large marginal returns to capital to the fact that many developing countries face higher political risk than industrialized ones (Azzimonti and Sarte 2007, 288). Similarly, Butler and Joaquin $(1998,599)$ define political risk 'as the risk that a sovereign host government will unexpectedly change the 'rules of the game' under which businesses operate.' The authors show how political risk can affect the future cash flows of FDI and how political risk can be factored into the required rate of return.

Some scholars have argued that qualitative assessments of institutions or of the investors themselves are necessary for a strong picture of Country Risk. For example, Biglaiser and Staats (2008) have argued for the importance of using qualitative research on the decisions from foreign investors themselves. Biglaiser and Staats (2008) use questions that relate to political, economic, and geographic factors through the administration of surveys to chief executive officers (CEOs) of U.S. firms with operations in Latin America to understand what influences their investment decisions. They argue that while imputing the motivations of investors based on broad economic and political measures is justified when there are no other qualitative or survey-based indicators, they ultimately conclude going directly to the source is better for understanding investor motivations (Biglaiser and Staats 2010, 508).

Some authors have argued that the quality of institutions can be used as an indicator of the level of Country Risk. Azzimonti and Sarte (2007) state that a distinctive characteristic of FDI is that once an investment has been made, a foreign investor cannot 
prevent the government in the host country from changing the environment in which the investment decision was made. Despite attempts to establish international tribunals, contracts between multi-national corporations and sovereign countries are almost impossible to enforce (Azzimonti and Sarte 2007, 287). The quality of institutions, and in particular, the degree of protection of property rights, are key in determining the expected return to foreign investors (Azzimonti and Sarte 2007, 287-288). Thus it follows that countries with relatively poor legal protection of assets, and a high degree of political instability, generally exhibit high rates of expropriation and this makes investment less attractive. In practice, expropriation can take different forms. A direct act of expropriation involves nationalization of foreign-owned corporations, in which the government simply takes control of the capital stock (Kobrin 1980, 1984). There are also indirect forms of expropriation that multinational corporations face. Examples include excessive taxation, capital controls, manipulation of exchange rates, and bribes and permits demanded by government officials (Azzimonti and Sarte 2007, 288).

As Jensen and Young (2008) note, several studies use FDI flows as the dependent variable to study the economic consequences of civil war, and the results vary. Nigh (1985), Enders and Sandler (1996), Li (2006), Jakobsen and de Soysa (2006), and Blomberg and Mody (2007) find that past violence has a negative effect on FDI, although Loree and Guisinger (1995) and Globerman and Shapiro (2003) find mixed results, and Fatehi-Sedeh and Safizadeh (1989), Li and Resnick (2003), and Sethi et al. (2003) find no relationship at all (Jensen and Young 2008). Their measurement of Country Risk is conceptualized as the risk that a government in a host country will unexpectedly change 
the institutional environment within which businesses operate. Therefore, from a financial perspective, Country Risk may alter operating cash flows via discriminatory policies and regulations. Liargovas and Skandalis conclude that a country with high Country Risk will be less appealing to foreign investors and use the PRS group data to measure this $(2012,326)$.

$\underline{\text { War }}$

The presence of War would seem, on the surface, to greatly influence FDI flows over time. War is an expression of instability and throws borders, the polity, and economy all into flux. The presence or anticipation of armed conflicts plays a potentially crucial role in disrupting not just trade flows (Long, 2008) but also foreign investment. Furthermore, war risk includes hostile actions taken by national or international forces, civil war, revolution, insurrection, or terrorism. By avoiding conflicts and ensuring political stability, host countries can thus create an environment that is favorable to FDI (Bussmann 2010, 143). To that end, this study assesses the literature on three types of War - Interstate, Intrastate, and Extrastate - and their effects, if any, on FDI flows over time.

Interstate War is defined by the Correlates of War project as "wars that take place between or among states (members of the interstate system)" (Jones 1996). Liberal peace scholars have pointed to many advantages of economic exchange, finding that FDI tends to reduce the likelihood of interstate conflict and civil war (Lee and Mitchell 2012, 675). Increased FDI can reduce the chances for dyadic militarized conflicts and improve 
interstate cooperation levels (Lee and Mitchell 2012, 676). However, some studies find that military conflict has no significant effect on FDI flows (Lee and Mitchell 2012, 677).

Other scholars have demonstrated that Interstate War can have a positive correlation with FDI (Biglaiser and DeRouen 2007) - this is known as the 'follow the flag" dynamic. In the initial stage of U.S. multinational enterprises decisions to invest, FDI flows are negatively affected by conflict and fewer capital controls and positively impacted by U.S. troops, alliance portfolio similarity, and regime type. "Follow the flag" factors are important determinants in the initial decision to invest abroad. In the second stage, the amount of FDI is the dependent variable (Biglaiser and DeRouen 2007, 836).

Investment stability provided by U.S. troops and foreign policy similarity are important indications that economic and security goals are not mutually exclusive. Although the presence of troops may be initially in response to acute crises and does not foster American investment, through U.S. government agencies such as Overseas Private Investment Corporation (OPIC) that offer risk insurance and other financial incentives to U.S. firms, the presence of U.S. troops within a country serves as a catalyst for U.S. FDI (Biglaiser and DeRouen 2007, 836). Second, the outsourcing of military functions to mostly U.S. private contractors in war-zone areas further attracts U.S. FDI. The fact that global FDI is negatively correlated with the stationing of U.S. ground troops reinforces the significance of OPIC and U.S. private contracting. Rather than discouraging FDI, troops and the pursuit of U.S. foreign policy goals appear attractive to U.S. investors (Biglaiser and DeRouen 2007, 836-837). 
Intrastate War is defined by the Correlates of War project as a "war that predominantly takes place within the recognized territory of a state" (Jones 1996). As with Interstate War, Intrastate War also can be potentially detrimental to FDI flows. As Feng and Chen (1997) note, Barro (1991) and Grier and Tullock (1988) find that political and social uncertainties manifested by revolutions, assassinations, and coups d'etat discourage private investment. Schneider and Frey (1985) conclude that riots and strikes have a negative impact on foreign direct investment (Feng and Chen, in Arbetman and Kugler, eds. 1997: 103).

While not definitionally the same, terrorism can be seen as similar to Intrastate War insofar as it can be waged by domestic actors against the state. To that end, terrorism has been shown to have a negative effect on FDI (Enders, Sachsida, and Sandler 2006; Enders and Sandler 1996) However, there is substantial evidence that terrorism's effects can be diminished because of the existence of business-related and non-business-related terrorism (Powers and Choi 2012).

Extrastate War is defined by the Correlates of War project as "wars that take place between a state(s) and a non-state entity outside the borders of the state" (Jones 1996). In the Middle East region for the period under study there are not many incidents of Extrastate War, however there are indicators of political instability. It is instructive, however, to address the scholarship that considers the impact of domestic political instability and terrorism on flows of FDI.

Adji, Ahn, and Holsey (1997) used a measure of domestic instability in their effort to delineate and quantify the effects of macroeconomic, political, and political 
performance effects on FDI. They hypothesized that domestic political instability in a country, such as political demonstrations, strikes, and riots, may disrupt the economy by increasing uncertainty about future economic policies, and thereby increasing the risk associated with any expected future start of profits. Domestic political instability may also adversely affect investment by generating concern about physical violence toward foreign investors' property and employees (Adji, Ahn, and Holsey 1997, 133). 


\section{Chapter 2 - Theory, Model, and Hypotheses}

Theory

As noted in the Literature Review, above, scholarship on the determinants of foreign direct investment (FDI) variously argue the influence of GDP growth, the openness of a country's its economy, a government's level of political capacity, the level of country risk, and the negative effects of inter-, intra- and extrastate conflict. These studies on the various effects on FDI, while providing insightful and substantial statistical results, fail to capture the simultaneous effects of these macroeconomic, political, country risk, and war variables.

To answer the question of what are the determinants of the variance in foreign direct investment flows in the Middle East over the time period of 1993 - 2007 this study is predicated on the proposition that investors make decisions based on return of investment, predictability and stability of investment climate, and predictability or lack of impediments to investments caused by conflict. Therefore, this study proposes the theory that regional FDI flows over time are explained by a combination of four un-weighted classes of variables: Macroeconomic, Government Performance, Country Risk, and War. Additionally, this study undertakes a country-level sub-analysis of selected countries from the regional group to test the theory's application at the country level. To that end, due to the somewhat arbitrary construction of a "region" we can expect that the movers of FDI at the country level will be inter-country similar, yet in the aggregate (i.e. the regional level) they will be different. Therefore, a more detailed discussion of the 
relevance of the coefficients for each country will be undertaken in the country analysis section of this study.

It is plausible that the four classes of variables chosen for this study are movers of yearly flows of foreign direct investment because FDI is susceptible to these major pillars of political economy. If it is accepted that political economy can be broken down to four distinct phenomena moving together - macroeconomics, government performance, a country's economic risk environment, and the presence or absence of conflict - then it follows that the investment choices of outside entrants into a host country's economy will be influenced by these four classes. The justification for these four indicators is as follows. Foreign direct investment is a macroeconomic occurrence that is instigated by investors, approved by governments, undertaken through analysis of the investment climate, and can be impeded, or in some cases advanced, by conflict.

This study uses quantitative measures to operationalize the four classes of variables. The importance of quantitative measures is that they can be replicated and the moving parts readily identified across all regime types, economies, and time. The present study addresses multiple regime types, levels of economic development, and spans a period of time where inter- and intra-country dynamics have been affected by changes in regimes and war.

Model, Methodology and Statistical Technique Used

The influences on yearly international flows of direct investment are conceptualized using seven un-weighted independent variables. In order to determine the 
most statistically relevant variables from the four classes (macroeconomic, political, country risk, and war) moving FDI flows from 1993 - 2007, this study employs a stepwise linear regression model. Linear regression estimates the coefficients of the linear equation, involving one or more independent variables that best predict the value of the dependent variable.

To determine the predictors for yearly flows of FDI over time, the following linear regression model was used.

$\mu\left\{\mathrm{Y} \mid \mathrm{X}_{\mathrm{n}}\right\}=\beta_{0}+\beta_{1} \mathrm{X}_{\mathrm{n}}$

Where $\mathrm{Y}$ equals FDI and $\mathrm{X}$ is the selected predictor variable.

Data for the macroeconomic variables comes from the World Bank (2012) and the Penn World Tables (Heston 2002). Government Performance data comes from the 2012 dataset on Government Performance (Yesilada 2012). Country Risk data comes from Euromoney, and war data comes from the Correlates of War project. The data for FDI contained values that were both negative and zero. To achieve a proper distribution of the sample, a value of 10 was added to all data points and then a Log 10 transformation was performed, yielding a normal distribution.

\section{Hypotheses}

Based on the above variables, this study tests the following five hypotheses.

Hypothesis One: GDP growth rate (annual percentage) 
The annual percentage that a country's GDP grows is an indication of the increase in earnings due to exports or investment. If a country experiences GDP growth over time, then FDI will increase. This suggests that there will be a positive correlation between GDP growth and FDI over time.

Hypothesis Two: Openness

A country's Openness is its control of the sum of imports and exports to GDP. It is a political indicator as it is an expression of the degree of ingress and egress of funds to the country allowed. If a country has a high amount of Openness we can expect that there will be a positive relationship with FDI.

Hypothesis Three: Government Performance

A country's Government Performance is a measurement of its ability to extract resources from the population to further the pursuit of national goals. It is a measure of the ratio of tax to GDP and is not dependent on its relative size of GDP ppp to other countries. Since FDI attraction may or may not be a national goal, it is unpredictable whether or not there is a positive correlation of RPE with FDI. The null hypothesis is that there is no relationship between RPE and FDI.

Hypothesis Four: Country Risk

Country Risk directly affects returns on investment, cost of business, and the repatriation of capital. If a country has a high degree of risk then it will have a low amount of FDI, similarly if a country has a low degree of risk then it will have a higher 
relative amount of FDI. Note that the higher a country's score, the lower its degree of risk. This suggests that a higher Country Risk score, which equates to a lower degree of risk, will correlate positively with FDI.

Hypothesis Five: War

War is a direct measure of armed conflict with significant deaths and casualties. Investors are wary of an environment where conflict is present as it suggests an unstable environment for business. This suggests that War negatively correlates with FDI.

\section{Table 1 Predicted Effects}

\begin{tabular}{|l|l|l|}
\hline $\begin{array}{l}\text { Determinants of Foreign } \\
\text { Direct Investment }\end{array}$ & $\begin{array}{l}\text { Variables Used in this } \\
\text { Study }\end{array}$ & $\begin{array}{l}\text { Predicted Effect } \\
\text { on FDI }\end{array}$ \\
\hline Macroeconomic & $\begin{array}{l}\text { GDP Growth Rate } \\
\text { (annual \%) } \\
\text { Openness }\end{array}$ & + \\
\hline $\begin{array}{l}\text { Government } \\
\text { Performance }\end{array}$ & $\begin{array}{l}\text { Relative Political } \\
\text { Extraction }\end{array}$ & $+/-$ \\
\hline Country Risk & Country Risk & + \\
\hline & & \\
\hline War & Interstate War & - \\
\hline & Intrastate War & - \\
\hline & Extrastate War & - \\
\hline
\end{tabular}




\section{Chapter 3 - Unit of Analysis and Variables}

\section{$\underline{\text { Unit of Analysis }}$}

The unit of analysis in this study is the nation state in a given year. This study uses a cross-sectional and time-series analysis incorporating fourteen nation states (Bahrain, Egypt, Iran, Iraq, Israel, Jordan, Kuwait, Oman, Pakistan, Qatar, Saudi Arabia, Syria, Turkey, and the United Arab Emirates over the period of 1993-2007). These units provide a set of 197 observations.

This time series captures global dynamics of FDI and lends itself to comparison of similar studies of the determinants of FDI flows over a similar period. For example, Morrissey and Udomkerdmongkol (2012) argued that by using the Kaufmann, Kraay, and Mastruzzi (2010) data allowed them to distinguish different elements or indicators of governance, but restricted the coverage to the period since 1996. The recent period of this study is appropriate as there was a global increase in FDI for the mid-1990s and many countries implemented economic liberalization in the early 1990s that attracted FDI. Agosin and Machado (2007) report that the major increase in their "openness to FDI" index was during 1990-96, with only small changes after 1996. These global and policy influences on FDI are unlikely to confound inferences from a sample for the period 1996 -2009 (Morrissey and Udomkerdmongkol 2012, 437).

Furthermore, this data set incorporates states that are both in the early stages and the mature stages of economic development, giving it a large explanatory power of how political and economic factors can move FDI regardless of stage of development. 
Additionally, the countries selected represent a large variance in GDP growth, openness of economy, government performance, country risk, and presence of war.

\section{Defining and Identifying Local Hierarchies}

The units of analysis are aggregated into a political-geographic region defined as the Middle East - a regional hierarchy within the global hierarchy as first defined by A.F.K. Organski (1958). The Middle East is a region of perpetual interest due to its geopolitical dynamics and its role as a hub for energy production and trade dynamics with other regions. This study's definition of the Middle East hierarchy draws from, but contrasts with, Lemke's (2002) method of identifying regional hierarchies. Lemke's (2002) formulation of identifying local hierarchies, i.e. a hierarchy in a politicalgeographic region, is that the members will consider each other when developing their foreign policies and planning for various military contingencies (68). Since this study is undertaken in the broader context of power transition theory, states in a hierarchy must have the ability to fight with each other (Lemke, 2002: 68). Thus, Lemke locates states in hierarchies based on a notion of proximity and interaction and the ability to interact militarily. Specifically, a hierarchy is composed of "sets of dyads with the ability to reach each other militarily; each state within a dyad has the ability to exert military influence within the other's territories." Lemke considered military potential, power projection, terrain, and distance to generate a list of regional subsystems. The problems here are apparent. Military capabilities change over time and are affected by technology. Terrain and distance can be overcome and power can be projected through computers etc. Lemke's formulation, even for 2002, does not take into account non-hardware or 
intangible military interactions. For example, one of the greatest threats to states comes in the form of cyber-warfare.

Additionally, Lemke has rejected the various approaches of identifying local hierarchies based on a combination of cultural similarities, trade patterns, common IGO membership, alliances, demographic similarities, and geographic proximity. He argues that neither of these tendencies is completely useful in either a general sense or in terms of his specific evaluation of the multiple hierarchy model (Lemke, 2002: 68). Based on the above formulations and criteria, Lemke defines the Middle East as fifteen states: Bahrain, Egypt, Iran, Iraq, Israel, Jordan, Kuwait, Lebanon, Oman, Qatar, Saudi Arabia, Syria, Turkey, the United Arab Emirates, and Yemen (2002).

This study, however, is not convinced that Lemke's formulation of a Middle East hierarchy is conceptually correct when assessing the subjective perceptions of other states and their polities when they think of the Middle East. When assessing the attraction of FDI, the conceptual aims of the analysis must be taken into account. It is reasonable to state that as of the writing of this study, in the popular imagination of the West, the Middle East is considered to include Pakistan, due to its proximity to the other Middle Eastern countries, its geopolitical role, and its nexus with terrorism and extrastate war. This study also departs from Lemke's definition of the Middle East due to the availability of data for Yemen, and for that reason Yemen was no considered in the analysis. 


\section{$\underline{\text { Variables }}$}

The Dependent Variables

Dependent Variable 1: FDI/Capital Flows at the regional level

The first dependent variable is yearly international flows of FDI in the Middle East. FDI in the Middle East has grown nearly 3400 percent from 1993-2007 (World Bank, 2011). FDI are the net inflows of investment to acquire a lasting management interest (10 percent or more of voting stock) in an enterprise operating in an economy other than that of the investor. It is the sum of equity capital, reinvestment of earnings, other long-term capital, and short-term capital as shown in the balance of payments (World Bank, 2011).

FDI is measured as the net inflows in the reporting economy (\% of GDP) as reported by the World Bank (2012). Due to the use of linear regression in assessing the effects of the independent variables on FDI the FDI data is transformed through a logarithm to improve the linearity.

Dependent Variable 2: FDI/Capital Flows at the country level

The second dependent variable is yearly international flows of foreign direct investment in individual countries in the Middle East region. These countries are selected based on geopolitical interest and their representativeness of what might be assumed to be the strongest variable moving FDI. For example, it could be assumed that in countries with a recent history of war such as Iraq, war is the strongest intervening 
variable in limiting FDI. Similarly, a country's level of Government Performance, such as in Israel, could be considered the prime mover of FDI inflows. To that end, a country that quantitatively exemplifies the effects of each independent variable is selected to empirically assess whether or not that independent variable has the same effect on FDI in the stepwise regression model at the country level as it does at the regional level.

The Independent Variables

The independent variables of this study are organized into four categories: Macroeconomic, Government Performance, Country Risk, and War.

Macroeconomic

Independent Variable 1: GDP growth (annual \%)

GDP growth in the Middle East has increased 11.29 percent from 1993-2007. Data for this measurement comes from the World Bank Economic Indicators of 2012. Independent Variable 2: Openness to Trade

Openness to trade must be considered as both a macroeconomic and a political mover of FDI because it is both a quantifiable expression of the ingress and egress of trade, and it conceptually captures the political willingness to allow such. Openness to trade in the Middle East has increased 20 percent from 1993-2007.

Openness to Trade ("Openness" or "OPENC") data comes from the Penn World Tables (Heston 2002) which uses the following equation: exports plus imports divided 
by GDP equals the total trade as a percentage of GDP. The export and import figures are in national currencies from the World Bank and United Nations data archives. Note that when the export and import figures and GDP are expressed in real values, the value of OPENC will be the same because the price level (conversion factor) for DA and exports and imports is the same.

Political

Independent Variable 3: Government Performance

Government Performance is measured using the data for Relative Political Extraction (RPE). RPE is the ability of governments to appropriate portions of the national output to advance public goals and is an expression of the degree to which a regime is stable (Arbetman and Kugler, eds. 1997). This study uses the RPE measurement with the agriculture control ratio because it allows states that are heavily dependent on agriculture to be compared with states that are more developed and diversified in their economy.

Data on RPE comes from a data set compiled by Yesilada et al. (2012) using primary sources from the World Bank economic indicators. This study uses the Frontier Extraction measurement of RPE.

Country Risk

Independent Variable 4: Country Risk Measurement 
Country Risk is the investment risk of a country, such as risk of default on a bond, risk of losing direct investment, risk to global business relations, and repatriation of capital. Country Risk must be considered when assessing FDI flows over time because it captures the political and economic climate of a country, and when aggregated of a region.

The Country Risk measurement captures many economic and macroeconomic variables that other studies have been disaggregated or treated as independent variables moving FDI (see above). This study uses data from the Euromoney Country Risk Rankings tables which evaluate the investment risk of a country, such as risk of default on a bond, risk of losing direct investment, risk to global business relations etc, by taking a qualitative model, which seeks an expert opinion on risk variables within a country (70\% weighting) and combining it with three basic quantitative values (30\% weighting) ("Country Risk Rankings 1993" 1993; "Country Risk Rankings 1994" 1994; "Country Risk Rankings 1995" 1995; "Country Risk Rankings 1996" 1996; "Country Risk Rankings 1997" 1997; "Country Risk Rankings 1998" 1998; "Country Risk Rankings 1999" 1999; "Country Risk Rankings 2000" 2000; "Country Risk Rankings 2001" 2001; "Country Risk Rankings 2002" 2002; "Country Risk Rankings 2003" 2003; "Country Risk Rankings 2004" 2004; "Country Risk Rankings 2005" 2005; "Country Risk Rankings 2006" 2006; "Country Risk Rankings 2007" 2007). The factors included in the ranking of countries by risk are: Political risk, Economic performance/projections, structural assessment, debt indicators, credit ratings, access to bank finance, and access to capital markets. The Euromoney Country Risk rating provides a composite measure and 
does not present problems of collinearity. The methodology used by Euromoney for their Country Risk score is as follows.

To obtain the overall Country Risk score, Euromoney assigns a weighting to six categories. The three qualitative expert opinions are political risk (30\% weighting), economic performance (30\%), and structural assessment (10\%). The three quantitative values are debt indicators (10\%), credit ratings (10\%), and access to bank finance/capital markets $(10 \%)$.

The qualitative average is produced by combining evaluations of political, economic, and structural assessments from experts around the world. When applying political, economic, and structural assessments to a 100 point scale for the qualitative average only (rather than the full Euromoney Country Risk score), the following weighting is used: political $43 \%$, economic $43 \%$, and structural $14 \%$.

The qualitative assessments of Country Risk are made as follows. For economic risk participants rate each country for which they have knowledge from 0-10 across 6 sub factors to equal a score out of 100. The categories of economic risk scored are as follows: bank stability/ risk; GNP outlook; unemployment rate; government finances; monetary policy/ currency stability. For political risk participants rate each country for which they have knowledge from 0-10 across 5 sub factors to equal a score out of 100 . The categories of political risk scored are as follows: corruption; government non-payments/ non-repatriation; government stability; information access/ transparency; institutional risk; regulatory and policy environment. 
For structural risk participants rate each country for which they have knowledge from 0-10 across 4 sub factors to equal a score out of 100. The categories of structural risk scored are as follows: demographics; hard infrastructure; labor market/ industrial relations; soft infrastructure. Individual experts must apply a value to each sub factor before their score is accepted into the system. Individual experts can also modify the sub factor weights to modify their effect on the overall score of 100 . The weight of an individual sub factor can be lowered to a minimum of $10 \%$ and to a maximum of $30 \%$. This allows the system to capture a second attribute along side of the evaluation of that category, which is the estimated effect of the category. For instance, a user may make a judgment that the single most important issue facing a given country is maintaining the stability of its currency, and so decide to increase the weighting of the monetary policy/ currency stability category from $20 \%$ to $30 \%$.

Within each sub factor, Euromoney Country Risk also asks experts for further information on the reasons behind each individual score, and these fall under the category of related factors. These are more like poll points, and do not directly affect the score. Instead, they inform a change made to a sub factor score and weight. For example, within the economic risk category of bank stability lie four further related factors: regulatory risk, trading exposures, asset quality and undercapitalization. Individual experts are able to add more related factors and ignore ones which are not applicable.

The quantitative score factors are derived as follows. For access to bank finance/capital markets participants rate each country's accessibility to international markets on a scale of $0-10(0=$ no access at all and $10=$ full access $)$. These scores are 
averaged and then weighted to $10 \%$. For debt indicators scores are calculated using the following ratios from the World Bank's Global Development Finance figures: total debt stocks to GNP (A), debt service to exports (B); current account balance to GNP (C). Developing countries which do not report complete debt data get a score of zero.

For credit ratings nominal values are assigned to sovereign ratings from Moody's, Standard \& Poor's and Fitch IBCA. The ratings are converted into a score using a set scoring chart. This score is then averaged and the score weighted to $10 \%$.

If a country has a high degree of risk then it will have a low amount of FDI, similarly if a country has a low degree of Country Risk then it will have a higher relative amount of FDI. Note that the higher a country's score, the lower its degree of risk. According to the hypothesis, a higher Country Risk score, which equates to a lower degree of risk, will correlate positively with FDI. Where there is no rating, countries score zero.

War

The measures of War for this study are in three categories: Interstate, Intrastate, and Extrastate War.

Independent Variable 5: Interstate War

The presence or absence of interstate war is measured with a dummy variable of either 1 or 0 , using the Correlates of War database on international conflict (Sarkees 2010). Interstate War is defined by the Correlates of War project as "wars that take place 
between or among states (members of the interstate system)." "Within the COW typology, an inter-state war must meet some definitional requirements of all wars in that the war must involve sustained combat, involving organized armed forces, resulting in a minimum of 1,000 battle-related combatant fatalities within a twelve month period. In Resort to Arms, Correlates of War scholars Melvin Small and J. David Singer further established the requisite condition that for a conflict to be a war, it must involved armed forces capable of "effective resistance" on both sides. The effective resistance criteria were specifically utilized to differentiate wars from massacres, one-sided state killings, or general riots by unorganized individuals. Such one-sided violence is not considered to be the same phenomenon as war and is not included here. As with all categories of war, for a state to be considered a war participant, the minimum requirement is that it has to either commit 1,000 troops to the war or suffer 100 battle-related deaths (Sarkees 2010).

A table of the interstate wars used in the time-series under analysis is included in Table 38 Interstate Wars.

Independent Variable 6: Intrastate War

The presence or absence of Intrastate War is measured with a dummy variable of either 1 or 0 , using the Correlates of War database on international conflict (Sarkees 2010). Intrastate War is defined by the Correlates of War project as a "war that predominantly takes place within the recognized territory of a state." Within the COW war typology, an intrastate war must meet the same definitional requirements of all wars in that the war must involve sustained combat, involving organized armed forces, resulting in a minimum of 1,000 battle-related combatant fatalities within a twelve month 
period. When Correlates of War scholars Melvin Small and J. David Singer first extended their study of war to include intra-state wars in Resort to Arms, they established the requisite condition that for a conflict to be a war, it must involve armed forces capable of "effective resistance" on both sides. They then developed two alternative criteria for defining effective resistance: "(a) both sides had to be initially organized for violent conflict and prepared to resist the attacks of their antagonists, (b) the weaker side, although initially unprepared, is able to inflict upon the stronger opponents at least five percent of the number of fatalities it sustains." The effective resistance criteria were specifically utilized to differentiate wars from massacres, one-sided killings, or general riots by unorganized individuals. Such one-sided violence is not considered to be the same phenomenon as war and is not included here. However, this distinction is sometimes difficult to make particularly in intrastate conflict (Sarkees 2010).

A table of the intra-state wars used in the time-series under analysis is included in Table 39 Intrastate Wars.

\section{Independent Variable 7: Extrastate War}

The presence or absence of Extrastate War is measured with a dummy variable of either 1 or 0 , using the Correlates of War database on international conflict (Sarkees 2010). Extrastate War is defined by the Correlates of War project as "wars that take place between a state(s) and a non-state entity outside the borders of the state'. "An extrastate war involves fighting a state system member outside its borders against the armed forces of an entity that is not a member of the state system. Within the current COW war typology, an extra-state war must meet some definitional requirements of all wars in that 
the war must involve sustained combat, involving organized armed forces, resulting in a minimum of 1,000 battle-related combatant fatalities within a twelve month period. The requirement for sustained combat resulting in a minimum of 1,000 battle-related deaths per year among all parties is a shift from the initial practice (in Wages of War and Resort to Arms) of counting only the system-member deaths." (emphasis in original) (Sarkees 2010).

A table of the extra-state wars used in the time-series under analysis is included in Table 40 Extrastate Wars. 


\section{Chapter 4 - Regional Analysis}

\section{$\underline{\text { Empirical Results }}$}

To answer the question of what are the determinants of FDI in the units of analysis, this study argues that FDI is moved by four classes of variables:

Macroeconomic, Government Performance, Country Risk, and War. Using a stepwise regression method, one model of predictors was generated. Follows is a discussion of the results in three parts. First, the validity of the findings is presented, addressing autocorrelation and multicollinearity. Second, the correlations of the independent variables with FDI are presented and discussed in relation to the hypotheses and the overall theory. Third, the results of the stepwise regression are presented and discussed in relation to the hypotheses and the overall theory. Last, the overall theoretical significance of the R-square and selected predictors are discussed, comparisons are made to the existing literature, and conclusions are drawn.

As discussed in the variables section, above, this study employs four variables that may be susceptible to first-order autocorrelation. They are the dependent variable FDI, the macroeconomic variables GDP Growth Rate and Openness, and the political variable of Relative Political Extraction. The test employed for autocorrelation was the Durbin Watson significance statistic. Here, $n=197$ and the Durbin Watson statistic is 1.540. Using the Savin and White (1977) tables for models where $n=150$ and there are 7 regressors plus an intercept term, the upper bound (dU) is 1.722 and the lower bound (dL) is 1.530. The observed value is not less than the $\mathrm{dL}$ nor is higher than $\mathrm{dU}$, and 
therefore the test for autocorrelation is inconclusive. However, because the observed value is so close to the $\mathrm{dL}$ it is necessary to consider the bounds where $n=200$. There, the $\mathrm{dL}$ is 1.603 , and $\mathrm{dU}$ is 1.746 . Therefore, while the null hypothesis cannot be categorically rejected, there is a possibility that there is first-order autocorrelation.

Next, multicollinearity was tested by examining the Variance Inflation Factors (VIF) and tolerances. For the predictive model generated for the regional analysis, the tolerances were well outside the bounds for multicollinearity to be a concern, as were the VIFs (see Table 2 Regional Analysis Coefficients).

While the stepwise regression model isolates those variables that most explain the FDI flows over time, an analysis of the correlations gives further insight into the dynamics surrounding FDI flows in this region. Follows is a discussion of the positive and negative correlations with attention paid to historical occurrences in the political economy of the region. For a full table of the correlations, see Table 3 Regional Analysis Pearson Correlation Coefficients.

As expected in this study's general theory, variances in FDI occurred in the presence of macroeconomic, government performance, country risk, and war. Variables that correlated positively with FDI, in order of classification, were GDP Growth (.102), Openness (.332), Government Performance (RPE) (.096), Country Risk (.129), and Intrastate War (.010). Openness was significant at 1\%, and Country Risk was significant at $5 \%$. Of these results two seem to stand out but only one is surprising. Country Risk correlates positively with FDI because the higher a country's score, the lesser the degree of risk; thus, positive fluctuations in Country Risk can be expected with positive 
fluctuations in FDI. Consistent with Hypothesis Two, Openness correlates positively with FDI.

Consistent with Hypothesis Three, Government Performance measured by RPE correlates positively with FDI. This study uses the new measurement of RPE that does not account for level of development or resource endowment. Whereas in other studies of government performance level of development is considered to be an intervening variable in the ability of countries to accomplish stated goals, the present study uses an agricultural control variable in order to compare countries side by side and with a parsimonious measure. This study draws on the following elaboration of the theory as proposed by Feng and Chen (1997). Feng and Chen proposed that, whatever the level of political capacity achieved, governments that increase or reduce political competency, or that continually vacillate between being a strong and a weak government, induce economic uncertainty, compared to governments whose political capacity is stable and consistent (1997, 98 - 99). Consequently whether weak or strong there is less political uncertainty with a government of stable political capacity than with a government whose political capacity varies. Such variation affects investment. Typically, an individual's decision to invest is based on two concerns: expected returns and variance of returns. If the level of return is kept constant, an increase in the level of the variance of returns will decrease the expected utility of the investment, assuming the commonality of riskaversion among investors. Political uncertainty, caused by the high variability of political capacity, increases the variance of the returns and thereby decreases the value of the investment (Feng and Chen 1997, 99). Thus, the positive correlation of RPE with FDI 
lends additional support to Feng and Chen's (1997) findings with the caveat that it still needs to be determined at the aggregate regional level or country level whether or not the attraction of FDI is a national goal which, if it is, can be supported by a higher degree of RPE.

The surprising positive correlation is that of Intrastate War. Follows is a discussion of what may explain this result and why it conflicts with this study's hypothesis. Hypothesis Five of this study states, "Investors are wary of an environment where conflict is present as it suggests an unstable environment for business. This suggests that War negatively correlates with FDI." Why Intrastate War correlates positively with FDI can be explained by addressing its frequency and context. First, there were four occurrences of Intrastate War during the time frame of this study (see ). Second, the occurrences were in only two countries - Iraq (1996) and Pakistan (2004, 2005, and 2006). In Iraq the conflict was the Sixth Iraqi Kurds conflict between the Iraqi government and the Patriotic Union of Kurdistan (PUK) which was a relatively shortlived conflict over local issues (August 31, 1996 - October 23, 1996) that resulted in a stalemate. The amount of deaths is unknown. In this instance it can be argued that due to the isolated nature of this conflict it had little effect on FDI flows in either Iraq or enough to impact the region. In Pakistan the Intrastate Wars from 2004 - 2006 were a civil war over local issues between the Pakistani government and the Waziri Tribes resulting in approximately 3000 deaths. Due to the isolated nature of the Waziri tribal lands and their low economic importance it can be argued that the conflict had little spillover effects and was of small concern to investors. Furthermore, in neither Iraq nor Pakistan (as discussed 
below in the country sub-analyses) did Intrastate War emerge as a predictor of FDI flows. Thus, what might explain the positive correlation with Intrastate War? Intrastate War could simply have been too infrequent and isolated in nature to have a negative effect on FDI.

Consistent with Hypothesis Five, Interstate War (-.069) and Extrastate War (.018) both correlated negatively with FDI at the regional level suggesting that where Interstate and Extrastate War is present there is a negative influence on FDI flows over time.

The stepwise regression generated one model of predictors, selecting all seven variables and producing a R Square of .209 (see Table 2 Regional Analysis Coefficients). The model representing this relationship is as follows:

$\mu\{\mathrm{Y} \mid \mathrm{X}\}=\beta_{0}+\beta_{1}($ Extrastate War $)+\beta_{2}($ Intrastate War $)+\beta_{3}($ GDP Growth $)+\beta_{4}$ $(\mathrm{RPE})+\beta_{5}($ Country Risk $)+\beta_{6}($ Interstate War $)+\beta_{7}$ (Openness)

Where Y equals FDI and X is the selected predictor variable.

This study theorizes that all four classes of variable - macroeconomic, government performance, country risk, and war - explain variance in FDI flows over time. The results of the stepwise regression confirm the theory and are discussed in greater detail below.

\section{Conclusions of Regional Analysis}


Consistent with this study's theory, the stepwise regression produced a model that is composed of multiple variables from four un-weighted classes and explains twenty percent of the variance in FDI. Openness, Country Risk, and GDP Growth were correlated most strongly with FDI flows over time, but Openness was three times positively correlated with FDI than the other variables.

The story of macroeconomics in the region for the period under study is that strong trade flows (Openness) are the best indicator of FDI flows over time. This result confirms the first and second hypotheses of this study: if a country has a high amount of Openness there may or may not be a positive relationship with FDI, and if a country experiences GDP growth over time, then FDI will increase. Unlike Coan and Kugler's study (2008), the present study argues that GDP Growth is but one of seven factors, each in a different class, that move FDI. While GDP Growth and Government Performance are conceptually and empirically important to FDI flows, they work in conjunction with other factors to produce FDI. Nonetheless, the present study supports Coan and Kugler's findings that macroeconomic factors are strong determinants of FDI flows.

Second, the story of Government Performance dynamics in the region for the period under study is that governments that are the most efficient at extracting resources from the population to further national goals represent a climate for positive FDI flows over time thus confirming numerous prior studies (Adji, Ahn, and Holsey 1997; Arbetman and Kugler 1997; Leblang 1997). Whereas Adji et al.'s (1997) study analyzed the effects of macroeconomic conditions and political environment on direct foreign investment using pooled cross-sectional, time-series data for 23 developing countries 
over the years 1970-1981, the present study uses a different time-series data set (1993 2007) that includes countries at different levels of development and employs the updated RPE measure with the agricultural control. Similar to Leblang (1997) the results of the present study suggest that there is a positive relationship between FDI and government performance.

Third, the stability and high positive score of a country's investment climate (Country Risk) correlates positively with FDI flows over time. This finding confirms Hypothesis 4 that states that "if a country has a high degree of risk then it will have a low amount of FDI, similarly if a country has a low degree of political risk then it will have a higher relative amount of FDI." This suggests that a higher amount of Country Risk will correlate negatively with FDI, and a lower amount of Country Risk will correlate positively with FDI. This study approaches the issue of Country Risk assessment from a slightly different angle than some of the literature, discussed further, below.

While questionnaires of investor opinion as to country risk have been employed as a way of determining risk and thereby determining a country's fitness for FDI (Biglaiser and Staats 2010, 508) there are methods that more closely comport with the conceptualization used in the present study. This study agrees with Jensen and Young that an appropriate mechanism linking violence to investment is investor perceptions of risk, in which forward-looking investors attempt to predict the likelihood of future political violence (Jensen and Young 2008). Furthermore, the present study agrees with them in that there is growing consensus that political risk is an important factor that greatly reduces the attractiveness of a foreign market for multinationals (Alfaro, Kalemli- 
Ozca, and Volovych 2005) and can alter a firm's entry strategy (Heinsz 2002). These risks range from the nationalization of industries (e.g., Cuba and Iran), to the canceling of contracts (India and the Philippines), restrictions on the repatriating of capital (Argentina and Malaysia), or political violence and war (Sierra Leone, Democratic Republic of the Congo, and Liberia). As with any other risk, the hesitancy of investors increases as the likelihood that political risks will materialize increases (Jensen and Young 2008, 529). They argue, however, that the way to accurately capture how risk is assessed in investment decision making is through the use of data on the price paid by investors to purchase risk insurance coverage. Jensen and Young $(2008,528)$ propose that the risk of violence is an important part of a measure of country risk and should be included in any assessment thereof. Their central theoretical aim is to explain the factors that shape investor perceptions of risk, and by using this measure they argue that their findings speak directly to the risk calculus (Jensen and Young 2008, 528).

This study uses information that investment firms and market watchers consider useful to their colleagues and the institutions they either represent or are familiar with. However, the present study uses a stronger measure of gauging investor temperament for FDI decision-making by employing the Euromoney Country Risk rankings, the methodology of which is both quantitative and qualitative, which yields stronger explanatory results.

A further difference between the present study and the literature is that Jensen and Young (Jensen and Young 2008) use risk as the dependent variable, whereas the present 
study employs risk as an independent variable. In that regard, this study is similar to others that use FDI as a dependent variable that is moved by risk.

The Young and Jensen (2008) study's use of a risk measure that incorporates violence is also conceptually problematic for the present study. The present study employs the Euromoney measure as it does not include violence, political instability, or war as a factor in country risk. Since the present study employs three separate measures of war, it avoids any problems with endogeneity that could arise if it were to employ a measure of risk that uses violence and war as one of several indicators making up the overall score of risk. Furthermore, Euromoney takes into account non-repatriation of capital. The issue here is that Euromoney measures Country Risk, and not the risk of violence. Thus the methodology is more germane to studying the effects on a dependent variable of FDI because the use of a country/political risk measure is based more on macroeconomic and political factors, and the use of Correlates of War measures is a direct measure of violence.

Fourth, the story of the effects of war on FDI flows over time is both expected and unexpected. As the correlations discussed above demonstrate, Interstate and Extrastate War had negative relationships with FDI flows but Intrastate War had a positive relationship. From a comparativist perspective this makes sense insofar as the Intrastate Wars examined coincided with an influx of foreign troops during the insurgency and the establishment of bases that were followed by an increase of foreign firms. To that end, Biglaiser and DeRouen have demonstrated that since the start of the Iraq war, FDI has flowed into Iraq. Among the top five countries investing in Iraq since 
2002, United States firms have by far the largest number of FDI projects (fifteen), followed by Egypt (three), and Germany, Jordan, and Kuwait (two each). Pentagon contracts awarded almost exclusively to U.S. corporations are partly responsible for the significant U.S. inflows (Biglaiser and DeRouen 2007, 835).

\section{Overall Conclusions as to the Efficacy of the Model Presented}

It can be concluded that the low R square of the study at the regional level can be attributed to a lack of consistency between all the countries in the group defined as the Middle East Region. The strengths of this study's methodology - a large $n$, a time series that captures a range of dynamics thereby avoiding selection bias, a large amount of variance in data, a Durbin Watson score that demonstrates a low chance of serial correlation, different types of regimes, the presence or absence of conflict - support the theory that FDI is moved by a variety of factors, and that one or two variables cannot accurately account for FDI flows over time. Most importantly, as will be demonstrated in the country level sub-analyses, below, the theory has a high explanatory yield at the country level. It makes empirical sense that the model yields a low $\mathrm{R}$ square at the regional level because of the variability of country dynamics. In the sub-analysis that follows, the model's utility is demonstrated in further refuting some assumptions that may attend a passing glance at a country. 


\section{Chapter 5 - Country Level Analysis}

\section{$\underline{\text { Introduction to Country Level Analysis }}$}

This study argues that yearly flows of FDI (\% of GDP) are moved by four classes of variables: Macroeconomic, Government Performance, Country Risk, and War. Country sub-analysis was performed in order to illustrate to what extent the country with the highest net change of FDI was affected by the independent variables and the extent to which the countries most representative of each independent variable were affected by that particular independent variable. Then the country results were compared to the regional analysis results. This was done in order to compare the regional aggregate effects of the independent variables on FDI with those countries for which it would be expected that the independent variable that most strongly impacts them compared to the countries as a whole, in order to determine whether or not the effect is any different from that at the regional level. Furthermore, it is important that the hypotheses formulated for each independent variable be tested in their most extreme quantification, vis-à-vis the aggregate.

The criteria for country selection were operationalized as follows. The subject of this study is the macroeconomic and political determinants of FDI over time. Therefore, for the dependent and independent variables where growth was a factor or where serial correlation may be present (FDI, GDP Growth, and Openness), and for which a net change over time was theoretically observable, the standard calculation for economic growth was employed to determine the rankings of each country, computed as follows: 
$\mathrm{PR}=($ VPresent - VPast $) /$ VPast $\mathrm{x} 100$

Where:

PR = Percent Rate

VPresent $=$ Present or Future Value

VPast $=$ Past or Present Value

The calculation for determining the ranking for the country representing

Government Performance is based on the theoretical platform that investors are attracted to countries where there is both a high level of government performance and consistent and stable performance over time. Therefore, the countries were ranked by median RPE and standard deviation. Thus, the country with the highest median and lowest standard deviation of RPE was the selected country.

The country with the lowest level of Country Risk was selected as follows. For any given year a country has a Country Risk score, independent of other countries, based on a hundred-point scale. To determine the country with the lowest risk (highest score) the country with the highest median was selected. Similarly, the country with the highest risk (lowest score) was determined by which country had the lowest median score.

The countries representing Interstate, Intrastate, and Extrastate War were based on the sum of their dummy variables. Thus, for any given year a country had either a 1 or a 0 for the occurrence or non-occurrence of any one of the three types of war. The country with the highest aggregate score for the time period was considered the representative 
country for that type of war. Thus, for Interstate War Iraq, Pakistan, and Turkey each scored 1. In Intrastate War Iraq, Pakistan, and Turkey scored 1, 2, and 0, respectively. In Extrastate War, Iraq, Israel, and Turkey scored 5,4, and 1, respectively. Therefore, for Intrastate War Pakistan was selected, and for Extrastate War Iraq was selected. In the case of Interstate War all countries eligible for sub-analysis - Iraq, Pakistan, and Turkey had a score of 1. Each of these countries appeared in sub-analyses for other variables and therefore no separate sub-analysis based solely on Interstate War was done. Instead, in addition to the focus variable special attention also was paid to Interstate War.

\section{Turkey Sub-Analysis: Greatest Net Change in Foreign Direct Investment}

In this sub-analysis, it is hypothesized that the positive correlations and predictors for FDI in the regional model will be as high, if not higher, at the country level. In order to determine the country with the greatest net change in FDI over the period of 1993 2007, a standard economic growth calculation was used to determine net growth for each country and then the median of the aggregate of all countries. Turkey experienced the largest net growth in FDI as a percentage of GDP at $866 \%$, compared to a median of $476 \%$ for the aggregate of countries during the same period. Note that Iraq experienced a net growth of FDI as a percentage of GDP of $1529 \%$. However, Iraq had an $n=10$, whereas for all other countries $n=15$. FDI was present in Iraq from $1997-2002$, and 2004 - 2007. For the years 1993 - 1996 and 2003 FDI was 0. Therefore, the selection of Turkey was made for two reasons. First, including a country with a different $n$ than other countries greatly skews the result. Second, if Iraq's net growth of FDI to be calculated using the standard economic growth model for the years 1997 - 2007 it would not capture 
the effect of a jump from zero to any percentage of GDP. To that end Turkey was selected as the country with the greatest net change in FDI and the one that is suitable to test the overall conclusions of the regional model with no particular attention paid to the effects of any one independent variable. Furthermore, Turkey is an interesting point of analysis due to its many political and economic reforms during the period of this study and can offer some interesting observations about FDI in these circumstances that are not measured directly or indirectly by any of the independent variables (thus avoiding any problems of endogeneity in the analysis).

The test employed for autocorrelation was the Durbin-Watson significance statistic. Here, $n=15$ and the Durbin-Watson statistic is 1.607. Using the Savin and White (1977) tables for models with seven regressors, an intercept term and where $n=$ 15 , the lower bound (dL) is .226 and the upper bound (dU) is 2.530 . The observed value falls directly between the $\mathrm{dL}$ and $\mathrm{dU}$ and the presence of autocorrelation is inclusive. However, to be conservative in the estimation, the null-hypothesis of zero autocorrelation cannot be rejected.

Next, multicollinearity was tested by examining the Variance Inflation Factors (VIF) and tolerances. Here, for the predictive models generated for the Turkey analysis, the range of the tolerances were well outside the bounds for multicollinearity to be a concern, as were the ranges of VIFs. Test results for Turkey are found in Table 4 Turkey Analysis Coefficients.

Compared to the correlations at the regional level, the results for Turkey were consistent (see Table 5 Turkey Analysis Pearson Correlation Coefficients). Of the 
variables, only GDP Growth (0.052), Openness (0.552), and Country Risk (0.111) were positive. Openness was significant at $5 \%$ and was consistent with the regional dynamic of Openness being the strongest correlation with FDI.

Variables that had a negative correlation were RPE (-0.262), Interstate War (0.185), and Extrastate War (-0.155). There were no occurrences of Intrastate War.

The stepwise regression of the seven independent variables used in this study against the dependent variable of FDI yielded an R square of .821 (see Table 4 Turkey Analysis Coefficients), with Extrastate War, Country Risk, Interstate War, GDP Growth, Openness, and RPE being selected as the predictors. The model representing this relationship is as follows:

$\mu\{\mathrm{Y} \mid \mathrm{X}\}=\beta_{0}+\beta_{1}($ Extrastate War $)+\beta_{2}($ Country Risk $)+\beta_{3}($ Openness $)+\beta_{4}(\mathrm{GDP}$ Growth $)+\beta_{5}(\mathrm{RPE})$

Where Y equals FDI and $\mathrm{X}$ is the selected predictor variable.

\section{$\underline{\text { Conclusions of the Turkey Analysis }}$}

A comparison of the Regional analysis with the Turkey analysis shows that the Turkey analysis had the same signs and all hypotheses were confirmed (see Table 6 Region vs. Turkey Pearson Correlation Coefficients Comparison). Additionally, Openness had the highest correlation with FDI and was the most significant variable at $5 \%$. The results for Turkey support the overall theory. The selection of all classes of predictors is what one might intuitively expect as indicators of FDI and reflects the 
regional analysis findings (see Table 7 Region vs. Turkey Selected Model Predictors Comparison).

In the case of Interstate War, qualitatively, before any analysis need be done, it could be predicted that the Interstate War variable in the analysis of Turkey would have little to no significance, correlation, or emerge as a predictor of FDI. The Interstate War in which Turkey was involved was the War for Kosovo in 1993 which lasted just 7 months and in which Turkey played a supportive role as an ally of NATO forces. Even though it was a war fought outside its borders, and in which Turkey incurred no battlefield deaths it nonetheless had a negative correlation with FDI flows.

\section{$\underline{\text { Saudi Arabia Sub-Analysis: Greatest Net Change in GDP Growth }}$}

This study hypothesizes that GDP Growth Rate will have a positive effect on FDI. If this is the case, then among all the countries under analysis it can be expected that the country with the greatest net change in GDP Growth will demonstrate the highest positive correlation to FDI compared to the regional aggregate.

In order to determine the country with the greatest net change in GDP Growth for the period of 1993 - 2007, a standard economic growth calculation was used to determine the net GDP Growth for each country and then the region. Saudi Arabia is the country among the selection group that demonstrated the highest net change in GDP Growth at $7638 \%$, compared to a regional median of $11 \%$.

The test employed for autocorrelation was the Durbin Watson significance statistic. Here, $n=15$ and the Durbin Watson statistic is 1.605. Using the Savin and 
White (1977) tables for models with seven regressors, an intercept term, and where $n=$ 15 the lower bound $(\mathrm{dL})$ is .226 and the upper bound $(\mathrm{dU})$ is 2.530 . The observed value falls directly between the $\mathrm{dL}$ and $\mathrm{dU}$ and the presence of autocorrelation is inconclusive. However, to be conservative in the estimation, the null-hypothesis of zero autocorrelation cannot be rejected.

Next, multicollinearity was tested by examining the Variance Inflation Factors (VIF) and tolerances. Here, for the predictive models generated for the Saudi Arabia analysis, the tolerances were well outside the bounds for multicollinearity to be a concern, as were the VIFs. Test results for the Saudi Arabia Sub-Analysis are in Table 8 Saudi Arabia Analysis Coefficients.

While the stepwise regression model isolates those variables that most explain the FDI flows over time and can demonstrate whether or not the overall theory is supported, an analysis of the correlations provides initial insight into the dynamics surrounding FDI flows in Saudi Arabia and a better indicator of support for this study's hypotheses. In particular, since Saudi Arabia had highest net change in GDP Growth at 7638\%, compared to a regional median of $11 \%$, this sub-analysis is concerned with Hypothesis One: "If a country experiences GDP growth over time, then FDI will increase. This suggests that there will be a positive correlation between GDP growth and FDI over time."

The analysis for Saudi Arabia GDP Growth correlated at 0.124 with FDI and Openness correlated at 0.729 and was significant at $1 \%$ with FDI, confirming Hypotheses One and Two (see Table 9 Saudi Arabia Analysis Pearson Correlation Coefficients). 
However, contrary to this study's Hypotheses Three and Four, Saudi Arabia saw a negative correlation with Government Performance (measured by RPE) (-0.215) and a low amount Country Risk (-0.070). Compared to the Pearson Correlation Coefficients at the regional level, the correlations for Saudi Arabia were inconsistent (see Table 10 Region vs. Saudi Arabia Pearson Correlation Coefficients Comparison). While GDP Growth and Openness had the expected sign, RPE and Country Risk did not.

The stepwise regression of the seven independent variables used in this study against the dependent variable of FDI yielded an R square of 0.567 (see Table 8 Saudi Arabia Analysis Coefficients), with Country Risk, Openness, RPE, and GDP Growth being selected as the predictors. The model representing this relationship is as follows:

$$
\mu\{\mathrm{YIX}\}=\beta_{0}+\beta_{1}(\text { Country Risk })+\beta_{2}(\text { Openness })+\beta_{3}(\mathrm{RPE})+\beta_{4}(\mathrm{GDP} \text { Growth })
$$

Where $\mathrm{Y}$ equals FDI and $\mathrm{X}$ is the selected predictor variable.

\section{Conclusions of Saudi Arabia Analysis}

The results of the stepwise regression confirm the general theory that FDI flows over time are moved by all classes of variables that are present (in this case Macroeconomic, Government Performance, and Country Risk). War as a fourth class was not present in the data and thus is moot as a class of variable. Additionally, the predictors selected in the model for Saudi Arabia were consistent with the Regional analysis and further confirmed the theory (see Table 11 Region vs. Saudi Arabia Selected Model Predictors Comparison). The results of the analysis for Saudi Arabia are clear. A country with high GDP Growth cannot rely on that for attraction of FDI. Consistent with 
Hypothesis One, the country with the highest GDP Growth saw a positive correlation of GDP Growth with FDI. However, of the two positively correlated variables (Openness and GDP Growth) Openness correlated more highly with FDI flows. In fact, Openness was significant at $1 \%$, thus lending very strong support to Hypothesis Two: "If a country has a high amount of Openness we can expect that there will be a positive relationship with FDI." This suggests that a country's favorable policies to the ingress and egress of trade can result in FDI. Last, Country Risk was not altogether surprisingly correlated negatively with FDI (recall that a higher score equals favorable country conditions). This could be due in part to its median score of 64.68 out of 100 which reflects macroeconomic factors such as debt service or repatriation of capital that are not fully captured by the GDP Growth Rate or Openness.

The high correlation of Openness demonstrates that FDI in this case was more affected by the macroeconomics of trade posture as measured by Openness than it was the rate of GDP Growth. Thus, even a country's relative higher GDP Growth cannot be counted on to be an indicator of its overall suitability as a place for FDI. The importance of Openness (its ratio of exports and imports to GDP) suggests that some combination of political and policy decisions and trade flows, undetectable by this analysis, explained the variance in FDI flows over time.

Unlike Coan and Kugler's study (2008), the present study argues that GDP Growth is but one of seven factors in different classes that move FDI. However, this study agrees with Coan and Kugler (2008) that economic indicators are strong predictors 
of FDI flows. While GDP Growth and RPE are conceptually and empirically important to FDI flows, they work in conjunction with other factors to produce FDI.

Iraq Sub-Analysis: Highest Net Change in Openness, Highest Level of Country Risk, and Most Occurrences of Extrastate War

As noted above, in this study countries have been selected for sub-analysis based on whether or not they have the highest median of some variables or highest occurrence of other variables. Iraq has had the highest net change in Openness, the lowest median score of Country Risk, and the most occurrences of Extrastate War. Therefore, this section of the sub-analysis will discuss each of these exemplar variables in turn rather than in sections unto themselves.

This study hypothesizes that Openness will have a positive effect on FDI. If this is the case, then among all the countries under analysis it can be expected that the Openness score of Iraq will correlate highly with FDI. Furthermore, this study argues that it is a combination of five classes of variables that move FDI, therefore it can be expected that Openness - a hypothesized macroeconomic indicator - will, either with or without the other macroeconomic indicator of GDP Growth, emerge as a predictor of FDI in the stepwise regression.

In order to determine the country with the greatest net change in Openness for the period of 1993 - 2007, a standard economic growth calculation was used to determine the net Openness change for each country and then the region. Iraq is the country among the 
selection group that demonstrated the highest net change in Openness at 89\%, compared to a regional median of $20 \%$.

In order to determine the country with the highest amount of Country Risk, the country with the lowest median score on a 100-point scale for the time period was selected. Iraq had the lowest median score at 4.96, compared to a regional median at 59.12 .

In order to determine the country with the most incidents of Extrastate War for the time period of 1993 - 2007, the country with the greatest sum of Extrastate Wars for the time period was selected. Iraq had five incidents of Extrastate War (Israel had the second-most incidents with four) and is thus selected as the subject of this sub-analysis.

As discussed in the variables section, above, this study employs four variables that may be susceptible to first-order autocorrelation. They are the dependent variable FDI, the macroeconomic variables of GDP Growth Rate and Openness, and the political variable of Government Performance measured by Relative Political Extraction. The test employed for autocorrelation was the Durbin Watson significance statistic. Here, $n=10$ and the Durbin Watson statistic is 2.885. Using the Savin and White (1977) tables for models with seven regressors, an intercept term, and where $n=10$, there is no tabled lower or upper bound. However, by following the accepted rules for determining the presence of autocorrelation, since the Durbin Watson statistic is approaching 4, it can be stated that there is negative autocorrelation. Therefore, the null-hypothesis of zero autocorrelation cannot be rejected. 
Next, multicollinearity was tested by examining the Variance Inflation Factors (VIF) and tolerances. Here, for the predictive models generated for the Iraq analysis, the tolerances were well outside the bounds for multicollinearity to be a concern, as were the VIFs. Test results for Iraq are found in Table 12 Iraq Analysis Coefficients.

While the stepwise regression model isolates those variables that most explain the FDI flows over time and can demonstrate whether or not the overall theory is supported, an analysis of the correlations provides initial insight into the dynamics surrounding FDI flows in Iraq and a better indicator of support for this study's hypotheses regarding Openness, High Country Risk, and Presence of Extrastate War. Follows is a discussion of these correlations, found in Table 13 Iraq Analysis Pearson Correlation Coefficients.

The variables negatively correlated with FDI were Openness (-0.515), RPE (0.781), and High Country Risk (-0.113). Thus, contrary to Hypothesis Two, Openness correlated negatively and was inconsistent with the regional results. Furthermore, contrary to Hypothesis Three RPE was negative and this result was significant at $1 \%$, the results of which are discussed further, below.

Compared to the stepwise regression at the regional level, the findings for Iraq as the country with the highest net change in Openness, High Country Risk, and Presence of Extrastate War were inconsistent. Of these three variables of focus, two had the opposite expected sign. Only GDP Growth at 0.215 was positively correlated as expected in Hypothesis One. Even more surprisingly, Extrastate War, contrary to Hypothesis Five, was positively correlated with FDI at 0.778 (see Table 14 Region vs. Iraq Pearson Correlation Coefficients Comparison). 
The stepwise regression of the seven independent variables used in this study against the dependent variable of FDI yielded an R square of 0.919 (see Table 12 Iraq Analysis Coefficients), with Extrastate War, Country Risk, Openness, GDP Growth, RPE, and Interstate War being selected as the predictors. The model representing this relationship is as follows:

$\mu\{\mathrm{YIX}\}=\beta_{0}+\beta_{1}($ Extrastate War $)+\beta_{2}($ Country Risk $)+\beta_{3}$ (Openness $)+\beta_{4}(\mathrm{GDP}$

Growth $)+\beta_{5}(\mathrm{RPE})+\beta_{6}($ Interstate War $)$

Where Y equals FDI and $\mathrm{X}$ is the selected predictor variable.

\section{Conclusions of Iraq Analysis}

In comparison with the Regional Model, the correlations were significantly different but the classes of predictors selected were the same (see Table 14 Region vs. Iraq Pearson Correlation Coefficients Comparison and Table 15 Region vs. Iraq Selected Model Predictors Comparison). Iraq's results supported the overall theory of FDI being moved by multiple classes of variables, but it did not lend support to the second hypothesis. In Hypothesis Two it was expected that Openness would positively correlate with FDI. On the contrary, Iraq's overwhelmingly high increase in Openness compared to the other countries did not result in a positive correlation with FDI.

Results for Country Risk were more in line with Hypothesis Four. Country Risk directly affects returns on investment, cost of business, and the repatriation of capital. If 
a country has a high degree of risk then it will have a low amount of FDI. This suggests that Country Risk will correlate negatively with FDI.

Iraq, with the highest median Country Risk over time, demonstrated a negative correlation with FDI. Unsurprisingly, Interstate War corresponded negatively with FDI, thus affirming Hypothesis Five.

The strong negative correlation of RPE with FDI - significant at $1 \%$ - soundly supports Hypothesis Three that states: "Since FDI attraction may or may not be a national goal, it is unpredictable whether or not there is a positive correlation of RPE with FDI. The null hypothesis is that there is no relationship between RPE and FDI."

Of most interest is the seemingly improbable positive correlation of Extrastate War with FDI. Extrastate War is a direct measure of war with significant deaths and casualties between states and non-state combatants where the borders and limits of conflict are unclear. Investors are wary of an environment where conflict is present as it suggests an unstable environment for business. If Extrastate War is present then FDI will remain static or decrease over time. This suggests that Interstate War negatively correlates with FDI. However, this result can be reconciled with the end of the Invasion of Iraq and the beginning of the Iraqi Resistance both in 2003. As the center of the country came under more control of the United States and its allied forces in 2003 at the conclusion of the Iraq Invasion, capital begin to flow in via contractors and multinationals. At the same time the Iraqi Resistance began. Thus, it is doubtful that Extrastate War is a precondition or indicator for potential or contemporary FDI in Iraq, but rather a coincidence of one war ending and an occupation and insurgency beginning. 
Israel Sub-Analysis: Highest Median Government Performance with the Lowest Standard Deviation of Government Performance

A country's Government Performance - measured by RPE - is its ability to extract resources from the population to further the pursuit of national goals. It is a measure of the ratio of tax to GDP and is not dependent on its relative size of GDP ppp to other countries. In this sub-analysis Hypothesis Four is tested: "Since FDI attraction may or may not be a national goal, it is unpredictable whether or not there is a positive correlation of RPE with FDI. The null hypothesis is that there is no relationship between RPE and FDI."

This study is predicated on the theory that investors prefer stability and predictability in markets for investment. While effective governance is preferable o ineffective or non-existent governance, stability and predictability offer parameters to make informed decisions. An assessment of RPE can provide us with a better understanding of a region that is dynamic and has great global significance due to its proximity to energy reserves, the colonial legacy, and its susceptibility to foreign military interventions and wars. The utility of Kugler at al.'s (2012) measure is that it has allowed scholars to measure the effectiveness and efficiency of governments vertically and horizontally - from the international to sub national levels. As such it may have a strong utility in forecasting and assessing the fluctuations of a state's FDI and their attendant economic and human development. 
Keeping this in mind, the country that typified RPE in the mind of the investor was the one with both the highest median RPE (indicating more effective governance) and the lowest standard deviation (indicating stability and predictability). For the period of 1993 - 2007 Israel had the highest median RPE at 1.45, compared to a regional median of 0.67 , and the lowest standard deviation of 0.08 , compared to a regional standard deviation of 0.12 .

The test employed for autocorrelation was the Durbin Watson significance statistic. Here, $n=15$ and the Durbin Watson statistic is 2.216. Using the Savin and White (1977) tables for models with seven regressors, an intercept term and where $n=$ 15 , the lower bound $(\mathrm{dL})$ is .226 and the upper bound $(\mathrm{dU})$ is 2.530 . The observed value falls directly between the $\mathrm{dL}$ and $\mathrm{dU}$ and the presence of autocorrelation is inclusive. However, to be conservative in the estimation, the null-hypothesis of zero autocorrelation cannot be rejected.

Next, multicollinearity was tested by examining the Variance Inflation Factors (VIF) and tolerances. Here, for the predictive models generated for the Israel analysis, the tolerances were well outside the bounds for multicollinearity to be a concern, as were the VIFs. Test results for Israel are found in Table 16 Israel Analysis Coefficients.

While the stepwise regression model isolates those variables that most explain the FDI flows over time and can demonstrate whether or not the overall theory is supported, an analysis of the correlations provides initial insight into the dynamics surrounding FDI flows in Israel and a better indicator of support for this study's hypothesis regarding Government Performance (measured by RPE). 
The correlations for Israel (see Table 17 Israel Analysis Pearson Correlation Coefficients) confirm Hypothesis Four: "Since FDI attraction may or may not be a national goal, it is unpredictable whether or not there is a positive correlation of RPE with FDI. The null hypothesis is that there is no relationship between RPE and FDI." RPE correlated negatively with FDI (RPE at -.0413) and was significant at 1\%. However, Extrastate War also correlated positively with FDI at 0.026. Compared to the correlations at the regional level, the findings for Israel as the country with the highest median RPE, and the lowest standard deviation of RPE were inconsistent with the regional results. The macroeconomic (GDP Growth at 0.312, Openness at 0.708 ), and Country Risk (Country Risk at 0.066) variables performed positively as expected (see Table 18 Region vs. Israel Pearson Correlation Coefficients Comparison).

The stepwise regression of the eight independent variables used in this study against the dependent variable of FDI yielded an R square of 0.758 (see Table 16 Israel Analysis Coefficients), with Extrastate War, Country Risk, Openness, GDP Growth, and RPE being selected as the predictors. The model representing this relationship is as follows:

$$
\mu\{\mathrm{Y} \mid \mathrm{X}\}=\beta_{0}+\beta_{1}(\text { Extrastate War })+\beta_{2}(\text { Country Risk })+\beta_{3}(\text { Openness })+\beta_{4}(\mathrm{GDP}
$$

Growth $)+\beta_{5}(\mathrm{RPE})$

Where Y equals FDI and $\mathrm{X}$ is the selected predictor variable.

\section{Conclusions of the Israel Analysis}


Compared to the stepwise regression at the regional level, all classes of predictors were selected and Israel's model supports the overall theory (see Table 19 Region vs. Israel Selected Model Predictors Comparison). Consistent with the regional analysis, Openness in Israel had the highest correlation with FDI. This suggests that perhaps observed trade flows and immeasurable policy factors are accounting for the most variance in FDI over time. The Israel model lends strong support to the dependent nature of RPE noted in Hypothesis Three. While RPE can facilitate FDI, RPE can only be a determinant of FDI if the target country has a policy of attracting FDI. This suggests that during the time period of analysis Israel did not have a strong policy of attracting FDI, a policy that cannot be measured or captured by the present study.

Surprisingly, Extrastate War correlated positively with FDI. This could be because the conflict, the Al-Aqsa Intifada of 2000 -2003 was won by Israel and Israel during that time, due to its high RPE and standing with the West (in particular the United States) was still able to attract FDI and sustain its economic growth.

\section{United Arab Emirates Sub-Analysis: Lowest Level of Country Risk}

Country Risk directly affects returns on investment, cost of business, and the repatriation of capital. If a country has a high degree of risk then it will have a low amount of FDI, similarly if a country has a low degree of country risk then it will have a higher relative amount of FDI. This suggests that a higher amount of Country Risk will correlate negatively with FDI, and a lower amount of Country Risk will correlate positively with FDI. 
In order to determine the country with the lowest amount of Country Risk, the country with the highest median score on a 100-point scale for the time period was selected. The United Arab Emirates had the highest median score at 74.68, compared to a regional median at 59.12 .

The test employed for autocorrelation was the Durbin Watson significance statistic. Here, $n=15$ and the Durbin Watson statistic is 1.867. Using the Savin and White (1977) tables for models with seven regressors, an intercept term and where $n=$ 15 , the lower bound (dL) is .226 and the upper bound (dU) is 2.530 . The observed value falls directly between the $\mathrm{dL}$ and $\mathrm{dU}$ and the presence of autocorrelation is inclusive. However, to be conservative in the estimation, the null-hypothesis of zero autocorrelation cannot be rejected.

Next, multicollinearity was tested by examining the Variance Inflation Factors (VIF) and tolerances. Here, for the predictive models generated for the U.A.E. analysis, the tolerances were well outside the bounds for multicollinearity to be a concern, as were the VIFs. Test results can be found in Table 20 United Arab Emirates Analysis Coefficients.

While the stepwise regression model isolates those variables that most explain the FDI flows over time and can demonstrate whether or not the overall theory is supported, an analysis of the correlations provides initial insight into the dynamics surrounding FDI flows in the United Arab Emirates and a better indicator of support for this study's Fourth Hypothesis regarding Low Levels of Country Risk. 
In the United Arab Emirates analysis all variables had the predicted sign and correlated with FDI as follows: GDP Growth 0.284, Openness 0.723, RPE 0.476, and Country Risk 0.191 (recall that a positive correlation of Country Risk with FDI is an indicator of low risk) (see Table 21 United Arab Emirates Analysis Pearson Correlation Coefficients). Most notably, RPE was significant at 5\% and Openness was significant at 1\%. As there were no incidents of War there were no correlations and thus the predicted outcome of negative correlations of War with FDI is moot. Compared to the correlations at the regional level, the correlations for the United Arab Emirates were consistent with the general model and all variables had the same sign and Openness was significant at 1\% (see Table 22 Region vs. United Arab Emirates Pearson Correlation Coefficients Comparison).

The stepwise regression of the eight independent variables used in this study against the dependent variable of FDI yielded an R square of 0.846 , with Country Risk, Openness, RPE, and GDP Growth being selected as the predictors (see Table 20 United Arab Emirates Analysis Coefficients). The model representing this relationship is as follows:

$$
\mu\{\mathrm{Y} \mid \mathrm{X}\}=\beta_{0}+\beta_{1} \text { (Country Risk) }+\beta_{2} \text { (Openness) }+\beta_{3}(\mathrm{RPE})+\beta_{4}(\text { GDP Growth })
$$

Where $\mathrm{Y}$ equals $\mathrm{FDI}$ and $\mathrm{X}$ is the selected predictor variable.

\section{Conclusions of the United Arab Emirates}

In the case of the U.A.E, the overall theory that FDI is moved by a combination of all classes of variables for which data is available is supported. The selection of all 
classes of predictors is consistent with the Regional analysis and further confirms the theory (see Table 23 Region vs. United Arab Emirates Selected Model Predictors Comparison). Consistent with the region, Openness is one of the most significant predictors of FDI - accounting for a large degree of the variance and correlating positively. Additionally, the results lend support to Hypothesis Four's prediction that where Country Risk is low, FDI will not be negatively affected.

\section{Pakistan Sub-Analysis: Most Incidents of Intrastate War}

Intrastate War is a direct measure of internal armed conflict with significant deaths and casualties. Investors are wary of an environment where conflict is present as it suggests an unstable environment for business. If Intrastate War is present then FDI will remain static or decrease over time. This suggests that Intrastate War negatively correlates with FDI.

In order to determine the country with the most incidents of Intrastate War for the time period of 1993 - 2007, the country with the greatest sum of intrastate wars for the time period was selected. Pakistan had three incidents of intrastate war (Iraq had the second-most incidents with one) and is thus the subject of this sub-analysis. Those three incidents were the Sixth Iraqi Kurds War of 1996 resulting in an indeterminate amount of battlefield deaths, and the Waziristan conflicts between allied Pakistani and United States forces, and the Waziristani tribes of the Federally Administered Tribal Areas near the northern Pakistan - Afghanistan border between 2004 and 2006 (equaling 2 incidents) 
resulting in approximately 1200 Pakistani and U.S. battlefield deaths and 1800 Waziristani battlefield deaths.

The test employed for autocorrelation was the Durbin Watson significance statistic. Here, $n=15$ and the Durbin Watson statistic is 1.347. Using the Savin and White (Savin 1977) tables for models with seven regressors, an intercept term and where $n=15$, the lower bound (dL) is .226 and the upper bound (dU) is 2.530 . The observed value falls directly between the $\mathrm{dL}$ and $\mathrm{dU}$ and the presence of autocorrelation is inclusive. However, to be conservative in the estimation, the null-hypothesis of zero autocorrelation cannot be rejected.

Next, multicollinearity was tested by examining the Variance Inflation Factors (VIF) and tolerances. Here, for the predictive models generated for the Pakistan analysis, the tolerance was well outside the bounds for multicollinearity to be a concern, as was the VIF. The test results for Pakistan are found in Table 24 Pakistan Analysis Coefficients.

The positive correlations for Pakistan were inconsistent with the hypotheses of the model (see Table 25 Pakistan Analysis Pearson Correlation Coefficients). GDP Growth (0.527) and Openness (0.823) produced the predicted sign as did Interstate War (-0.135). GDP Growth and Country Risk were significant at 5\%, and Openness was significant at 1\%. However, Intrastate War (0.437) and Country Risk (0.445) were unexpectedly positively correlated. Although it is theoretically possible in this model for Country Risk to correlate positively, in the case of Pakistan its median score was $35 / 100$ placing it third lowest of all the countries and 24 points below the group median. Variables that correlated negatively with FDI were RPE (-0.476) and RPE was significant at 5\%. 
Compared to the correlations at the regional level the results are not wholly inconsistent with only RPE correlating negatively (see Table 26 Region vs. Pakistan Pearson Correlation Coefficients Comparison).

The stepwise regression of the eight independent variables used in this study against the dependent variable of FDI yielded an R square of .797, with Intrastate War, Interstate War, Country Risk, Openness, GDP Growth, and RPE being selected as the predictors (see Table 24 Pakistan Analysis Coefficients). The model representing this relationship is as follows:

$\mu\{\mathrm{Y} \mid \mathrm{X}\}=\beta_{0}+\beta_{1}$ (Intrastate War) $+\beta_{2}($ Interstate War $)+\beta_{3}$ (Country Risk $)+\beta_{4}$ (Openness) $+\beta_{5}($ GDP Growth $)+\beta_{6}(\mathrm{RPE})$

Where $\mathrm{Y}$ equals FDI and $\mathrm{X}$ is the selected predictor variable.

\section{Conclusions of the Pakistan Analysis}

Compared to the regional analysis, all classes of variables were selected as accounting for the variance in FDI flows over time and therefore the results of the Pakistan model are consistent with, and lend additional support to, the overall theory (see Table 27 Region vs. Pakistan Selected Model Predictors Comparison). Again, consistent with the regional analysis results Openness correlated positively and emerged as the most significant predictor of FDI flows over time.

These results seem to comport with Klasra's (2011) findings regarding FDI, trade and openness. There it is argued that Pakistan and Turkey, since the 1980s, have been 
widely adopting reforms in their respective economies with the objective to set a good pace of economic development. Until 1980 both countries were following importsubstitution policies and import restrictions were quite high. Starting her trade liberalization during 1980s, Pakistan reduced tariff from 150 percent to zero percent until 1995, strengthened export incentive system and liberalized the import licensing system. Out of 5,464 goods, only 70 goods were listed on import restriction list. All export duties were removed with a few exceptions. Its export regime was liberalized to do away with public sector monopolies to permit full private sector participation (Klasra 2011, 224).

\section{Bahrain Sub-Analysis: Petroleum Dependent Country}

The movers of FDI over time in Bahrain are of interest because of its status as a country that is greatly dependent on petroleum for its GDP. To the hypothetical investor the suitability of a petroleum dependent country with proven reserves and for who prices are set by OPEC as a target country of FDI represents a quandary. Perhaps the same movers of FDI for other countries do not apply to a country that derives most of its revenue from domestic resources and has little to no incentive to attract FDI. To that end, Bahrain will be analyzed in the same manner as the region, with no attention paid to any one particular variable.

As in the regional analysis, the statistical process used for Bahrain was a stepwise regression using the seven predictors. The test employed for autocorrelation was the Durbin Watson significance statistic. Here, $n=15$ and the Durbin Watson statistic is 1.948. Using the Savin and White (1977) tables for models with seven regressors, an 
intercept term and where $n=15$, the lower bound (dL) is .226 and the upper bound (dU) is 2.530. The observed value falls directly between the $\mathrm{dL}$ and $\mathrm{dU}$ and the presence of autocorrelation is inconclusive. However, to be conservative in the estimation, the nullhypothesis of zero autocorrelation cannot be rejected. All war measures for Bahrain had no correlations due to them being a non-event for the period under study.

Next, multicollinearity was tested by examining the Variance Inflation Factors (VIF) and tolerances. Here, for the predictive models generated for the Bahrain analysis, the tolerances were well outside the bounds for multicollinearity to be a concern, as were the VIFs. The test results for Bahrain are listed in Table 28 Bahrain Analysis Coefficients.

While the stepwise regression model isolates those variables that most explain the variance of FDI flows over time and can demonstrate whether or not the overall theory is supported, an analysis of the correlations provides initial insight into the dynamics surrounding FDI flows in Bahrain and a better indicator of support for this study's hypotheses.

As expected in this study's general theory, variances in FDI occurred in the presence of macroeconomic, government performance, country risk (war was a nonoccurrence and so was not selected as a predictor). One variable correlated positively with FDI: Openness at 0.261 (see Table 29 Bahrain Analysis Pearson Correlation Coefficients). However, Openness was not significant at $5 \%$ and so cannot be considered to have a high determinative effect on FDI. Nevertheless, Hypothesis Two is supported: 
"If a country has a high amount of Openness we can expect that there will be a positive relationship with FDI."

Contrary to the majority of this study's hypotheses, Bahrain saw a negative correlation with GDP Growth (-0.391), RPE (-0.352), and Country Risk (-0.423). There is no support in the case of Bahrain for the hypotheses that GDP Growth, Government Performance (as measured by RPE), and low Country Risk correlate with FDI flows. Thus, Bahrain is inconsistent with the Regional analysis and had only one variable, Openness, with the expected sign (see Table 30 Region vs. Bahrain Pearson Correlation Coefficients Comparison). The negative correlation with Country Risk is surprising because Bahrain had a median score of $64 / 100$ (5 points above the group median), and had the fifth highest score out of the fourteen (100 points being the best possible score indicating lowest risk).

The stepwise regression generated one model and yielded an R square of 0.663 , with Country Risk, RPE, GDP Growth, and Openness being selected as the predictors (see Table 28 Bahrain Analysis Coefficients). The model representing this relationship is as follows:

$$
\mu\{\mathrm{YIX}\}=\beta_{0}+\beta_{1}(\text { Country Risk })+\beta_{2}(\mathrm{RPE})+\beta_{3}(\text { GDP Growth })+\beta_{4}(\text { Openness })
$$

Where $\mathrm{Y}$ equals FDI and $\mathrm{X}$ is the selected predictor variable.

\section{Conclusions of Bahrain Analysis}


Compared to the stepwise regression at the regional level, the findings for Bahrain were consistent. Since War was not present as a possible outcome for a predictor, the overall theory that FDI flows are moved by Macroeconomic, Government Performance, and Country Risk was confirmed (see Table 31 Region vs. Bahrain Selected Model Predictors Comparison). However, unlike the regional level, GDP Growth, RPE, and Country Risk are negatively correlated with FDI flows. Follows is a discussion of why these three variables may be negatively correlated.

The Bahrain economy is dependent on large exports of petroleum. Additionally, until recently most industry was state owned and it had a trade policy that discouraged, and in some ways made impossible, FDI. Thus, its GDP Growth rate was moved by its volume of petroleum exports and operated independently of other sources of economic growth and capitalization by policy design. In much the same way, the negative correlation of FDI with Country Risk occurs in the same way. Despite its very favorable risk rating, a policy that prohibits outside investment will result in a dynamic that may appear skewed when compared to other countries with more favorable policies toward FDI. The contrast of its Country Risk rating to the regional model is similar in that regard for two reasons. First, the majority of the countries under study are open to trade, yielding an positive relationship with FDI. Second, outlier occurrences like those of Bahrain are washed out by the aggregate of policies. The negative correlation of RPE with FDI may be attributable to an economy that in many ways pays the polity a subsidy and is not dependent on taxation of that polity to advance government goals. Simply, 
where there is no tax base and all industry is state-owned it will follow that RPE will be low.

\section{Iran Sub-Analysis: Country of General Interest}

The movers of yearly FDI flows over time in Iran is a subject of interest because of the international sanctions that the country is under, its position as a petroleum exporter, its pursuit of a civilian nuclear program, and its general significance in the popular western imagination as a state that can contribute to the overall instability of the region. The present study is useful because Iran can be looked at from an international relations perspective and a non-comparativist perspective. While a comparativist perspective is of no doubt great use to studying any country, in this situation it can be useful to first present Iran as a set of quantifiable variables for a hypothetical investor who has no knowledge of the internal politics and relationships with other major powers in the region or in relationship with the global dominant power. To that end, Iran will be analyzed in the same manner as the region, with no attention paid to any one particular variable.

This study argues that FDI is moved by four classes of variables: macroeconomic, government performance, country risk, and war. Using a stepwise regression method, one model of predictors was generated. Follows is a discussion of the results in three parts. First, the validity of the findings is presented, addressing autocorrelation and multicollinearity. Second, the correlations of the independent variables with FDI are presented and discussed in relation to the hypotheses and the overall theory. Third, the 
results of the stepwise regression are presented and discussed in relation to the hypotheses and the overall theory. Last, the overall theoretical significance of the Rsquare and selected predictors are discussed, comparisons are made to the existing literature, and conclusions are drawn.

As discussed in the variables section, above, this study employs four variables that may be susceptible to first-order autocorrelation. They are the dependent variable FDI, the macroeconomic variables GDP Growth Rate and Openness, and the political variable of Relative Political Extraction. The regional test results are listed in Table 2 Regional Analysis Coefficients. The test employed for autocorrelation was the Durbin Watson significance statistic. Here, $n=15$ and the Durbin Watson statistic is 0.862 . Using the Savin and White (Savin 1977) tables for models where $n=15$ and there are 7 regressors plus an intercept term, the lower bound $(\mathrm{dL})$ is .226 and the upper bound $(\mathrm{dU})$ is 2.530. The observed value is not less than the $\mathrm{dL}$ nor is higher than $\mathrm{dU}$, and therefore the test for autocorrelation is inconclusive.

Next, multicollinearity was tested by examining the Significance (1-tailed) score and Variance Inflation Factors (VIF) and tolerances. For the predictive model generated for the Iran analysis, the tolerances were well outside the bounds for multicollinearity to be a concern, as were the VIFs. The test results for Iran can be found in Table 32 Iran Analysis Coefficients.

In the following discussion, the degree to which the general theory of FDI determinants is supported is analyzed through the results of the positive and negative correlations of the dependent variable against the seven regressors. 
As expected in the general hypotheses and consistent with the regional results of this study, all macroeconomic variables (GDP Growth 0.516, Openness 0.680), government performance (RPE 0.393), and low country risk (a score of 40/100) (Country Risk 0.584 ) correlated positively with yearly flows of FDI over time (see Table 33 Iran Analysis Pearson Correlation Coefficients). GDP Growth and Country Risk were significant at $5 \%$ and Openness was significant at $1 \%$. Compared to the Regional analysis, the correlations for Iran were stronger and more significant, suggesting an excellent environment for investment (see Table 34 Region vs. Iran Pearson Correlation Coefficients Comparison). For the period under analysis, there were no incidents of all three types of war so their lack of correlation is moot.

The stepwise regression of the seven independent variables used in this study against the dependent variable of FDI yielded an R square of 0.462, with Openness selected as the sole predictor (see Table 32 Iran Analysis Coefficients). The model representing this relationship is as follows:

$$
\mu\{\mathrm{Y} \mid \mathrm{X}\}=\beta_{0}+\beta_{1}(\text { Openness })
$$

Where Y equals FDI and $\mathrm{X}$ is the selected predictor variable.

\section{Conclusions of Iran Analysis}

The predictor of Openness being the only one selected as accounting for the variance does not lend support to the general theory that yearly flows of FDI over time are moved by macroeconomic, government performance, country risk, and war factors (see Table 35 Region vs. Iran Selected Model Predictors Comparison). All other 
dependent variables in this study selected all the independent variables (where data was present) as predictors of yearly FDI flows over time. Here, Openness being selected as the sole predictor suggests that the variance in yearly FDI flows in Iran is attributable to macroeconomic factors only. Recall that Openness is operationalized as the ratio of the sum of exports and imports to GDP.

The existence of positive correlations with FDI by all the variables lends strong support for the general theory. Although there was only one regressor chosen as accounting for the variance in FDI flows over the period under study, the selection of Openness is helpful in assessing for the potential investor the conditions that lend themselves to a prudent decision to invest in Iran. Openness can be conceptualized as a variable that captures an unquantifiable posture of government to engage with other states through trade. Iran has been the target of numerous economic sanctions yet its outward posture has remained open to trade and has shown a positive orientation to have a macroeconomic policy that allows the ingress and egress of investment while other states may take measures to frustrate that posture. 


\section{Chapter 6 - Overall Conclusions and Limitations of the Model Presented}

\section{$\underline{\text { Overall Conclusions }}$}

Follows is a discussion of the overall conclusions drawn from the regional and country level analyses, and how the results of the correlations and predictors selected compare. For a side-by-side comparison of the Pearson Correlation Coefficients for the region and all countries under sub-analysis see Table 36 Region vs. All Country Sub-Analyses Pearson Correlation Coefficients Comparisons. For a side-by-side comparison of the selected predictors for the region and all countries under sub-analysis see Table 37 Region vs. All Country Sub-Analyses Selected Model Predictors Comparisons.

One of the most important findings of this study is the prominent role that Openness plays in accounting for the variance in FDI and in its significance in correlating with FDI at both the regional level and country level. In the sub-analysis of Iran where only one predictor was selected in the stepwise regression Openness was the one that was selected. Furthermore, Openness tended to correlate the highest with FDI and was significant at $1 \%$ for five of the eight country sub-analyses was significant at $5 \%$ for one, had the same sign for one, and was negatively correlated in only one instance. Openness suggests that there is a latent mover of FDI undetectable by the model of this study. This mover perhaps could be a country's policy orientation. If that is the case, then the findings of this study when used in conjunction with a comparativist approach could yield important insights as to the particular country dynamics and movers of FDI. 
The role of RPE in accounting for flows of FDI over time was less than expected. However, there are some conclusions that can be drawn from this. Government performance is an indicator of the potential of a government to carry out goals that it considers important to the national interest. Therefore, where FDI is considered to be a national goal then it can be expected that we will see a high correlation with Openness because Openness is a trade posture made tangible by the quantifiable ingress and egress of products and services. Thus, where Government Performance does not emerge in the regional analysis or in a country level analysis as significant may indicate that FDI is not a significant national goal. Indeed, in the Gulf states where there is a high dependency on revenue based on petroleum reserves and exports it can be observed that the correlations between FDI and RPE, FDI and Openness, and Openness and RPE are low.

Country Risk as a predictor of FDI flows performed as expected. It correlated positively with FDI (0.130) and was significant at 5\%. This follows with what may be intuitively expected by a hypothetical investor. Countries with low levels of economic risk (bank stability/ risk, GNP outlook, unemployment rate, government finances, monetary policy/ currency stability), low levels of political risk (corruption, government non-payments/ non-repatriation, government stability, information access/ transparency, institutional risk, regulatory and a favorable policy environment), and low structural risk (demographics, hard infrastructure, labor market/ industrial relations, soft infrastructure) will be seen as favorable to outside investors. Thus it is supported that an investor can gain a good picture of the predictors of FDI flows by looking at Openness and Country Risk alone. 
The presence of war or occurrence of past wars (or indeed anticipation of wars) were not as determinative of variance of FDI flows and did not always have a significant negative impact. The instructive conclusion of this for the hypothetical investor is that the intrastate geographic location, duration, and nature of the war are more important than the fact that it is a war (and embodies the attendant chaos that wars conjure up in the popular imagination). In that regard, the hypothetical investor should consult with regional or country experts before withdrawing FDI based solely on the presence of war.

The overall conclusion of this study is that variance of FDI flows are best conceptualized as stemming from the presence of multiple classes of predictors. The four classes of Macroeconomic, Political, Country Risk, and War are conceptually sound, and provide a full picture of investment dynamics. While the results were not robust at the regional level (for reasons explained above) they were particularly encouraging at the country level. Additionally, of great interest is that this model may be used in a diagnostic capacity to reveal the presence of a variable that is unique to one country. The Iran analysis demonstrated that where all variables had the expected sign and three out of four of those were at $5 \%$ or $1 \%$ the selection of only one predictor points to an exogenous dynamic affecting the variance of FDI. In all other sub-analyses where a variable was highly correlated it was selected as a predictor. The Iran results suggest that perhaps a variable like sanctions is effecting the ability of strong GDP Growth, good Government Performance, low Country Risk (all which normally indicate a good environment for investing) to effect FDI flows. Thus, the model generated by this study can be used as a 
diagnostic tool for countries whose FDI flows may be profoundly moved by unique and uncommon exogenous shocks.

\section{Limitations of the Model Presented}

The cases selection for this study was based on Lemke's (2002) definition of the Middle East with the addition of Pakistan. Pakistan was included due to its proximity to Iran and its recent geopolitical importance in the United States' military operations in the region. Some area studies scholars may disagree with this definition of the region, citing instead the United States Department of State ordering of the Middle East as Armenia, Azerbaijan, Bahrain, Gaza Strip, Georgia, Iran, Iraq, Israel, Jordan, Kuwait, Lebanon, Oman, Qatar, Saudi Arabia, Syria, Turkey, UAE, West Bank, and Yemen. Nevertheless, this study was predicated on data availability and a conceptualization of the Middle East that also maintains an element of arbitrariness to avoid issues of tautology were case selection be determined by trade blocks or on bilateral trade agreements. Future studies may consider apply stricter selection of cases or an expansion of the units of analysis in order to increase the sample size and the robustness of results. Similarly, future studies may employ this study's model to assess its applicability cross-regionally or globally.

This study faced limitations in its time series due to data availability or unreliability. Afghanistan would have been included had there been any reliable macroeconomic or stability indicator data preceding 2001. This study was also limited to cases ending in 2007, thereby unfortunately missing some macroeconomic, country risk, and war events of great significance. 
This study has considered other measurements of trade flows that may have been substituted for FDI as the dependent variable. For future research the relationship between FDI and portfolio flows should be considered. Assessing the correlations between them may indicate if one is moving the other. To that end data from the Coordinated Portfolio Investment Survey (CPIS) from the International Monetary Fund may be used.

As discussed in the variables section, above, this study employs four variables that may be susceptible to first-order autocorrelation. They are the dependent variable FDI, the macroeconomic variables GDP Growth Rate and Openness, and the political variable of Relative Political Extraction. While a great effort was made in the conceptual design of this study to avoid endogeneity and compound variables they still remain an issue. The Durbin-Watson test concluded that autocorrelation could not be ruled out, leaving the issue of compound variables requiring further assessment as it may present problems with a larger data set and greater time series.

Country Risk was measured based solely on macreconomic conditions. However, as noted in the literature review, there are other conceptualizations of risk that consider political conditions such as regime stability, forced elections or frequency of elections, institutional stability and so forth. Additional indicators of risk were considered but data availability proved to be a problem. For example, the Corruption Perception Index was considered as an additional independent variable but data points were not available for all countries for all years. Another type of risk that pertains to macroeconomic conditions is the risk that the investor themselves is willing to expose themselves to that 
is independent of third-party assessments of market or issue risk in target countries. Thus the perennial problem of the "emotional investor" and how to measure it is an issue that must be taken into account when calculating country risk.

Regime type was considered as independent variable moving flows of FDI. Future studies may want to consider using not just regime type but the degree of type using, for example, Freedom House ratings. One problem that this may raise is that variance must be considered when looking at more stable regions or aggregating stable regions with less stable as the fluctuations in degree of regime type in less stable countries may skew the correlations.

The last explanatory variable that may be refined regards Government Performance. This study used the measure of Relative Political Capacity. However, the measurement of Relative Political Allocation (RPA) may give an indication of the efforts a target country is expending to attract FDI, and not just its efficiency of government.

Last, a time series anlaysis of the region and the country studies was outside the scope of this study. Future research could take into account the time series effects of the independent variables and determine if the model has a forecasting ability. To that end, to find the best fit of a time series to past values of this time series the Box-Jenkins test could be employed.

Further applications of the model could be in combining historical data with forecasts of the significant macroeconomic variables of this study (Openness, GDP Growth and Country Risk) in order to delineate trends of FDI. Additionally, historical 
and forecasted Government Performance data can be useful alongside such a proposed application to determine whether or not Government Performance should be of concern when making decisions on FDI. Last, applications of the model could be made at the sub-national level by substituting violent crime rates for war. 


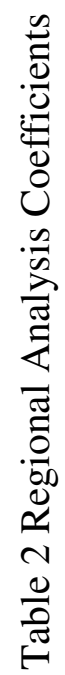

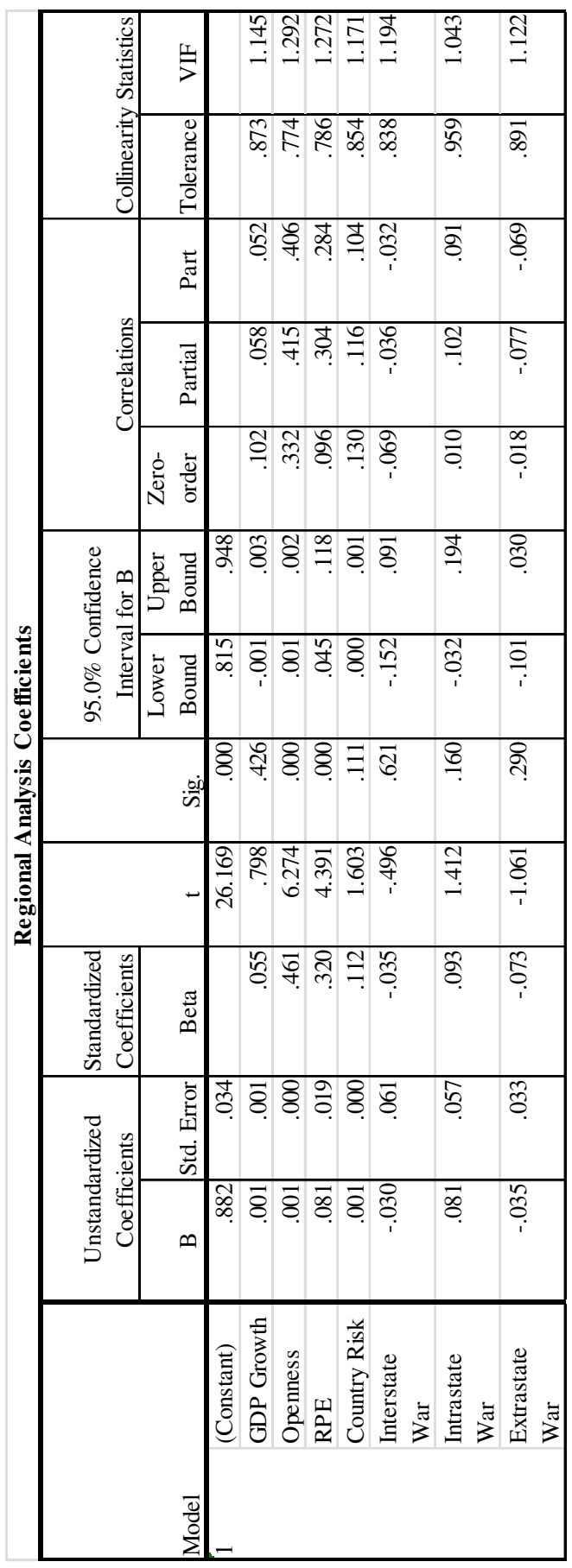




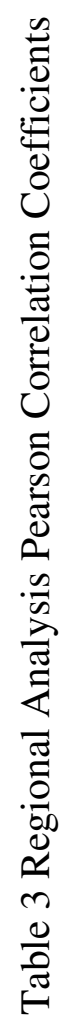

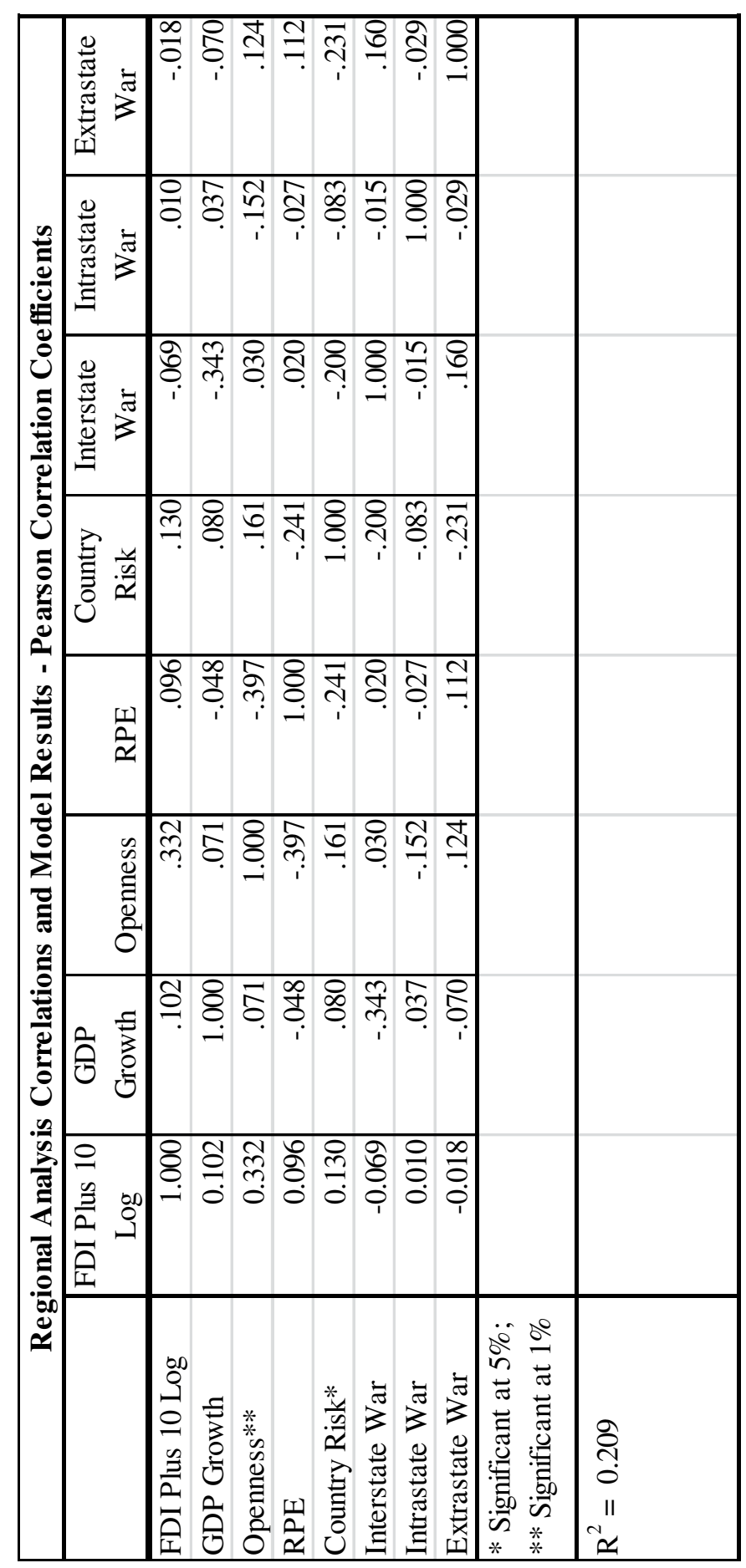



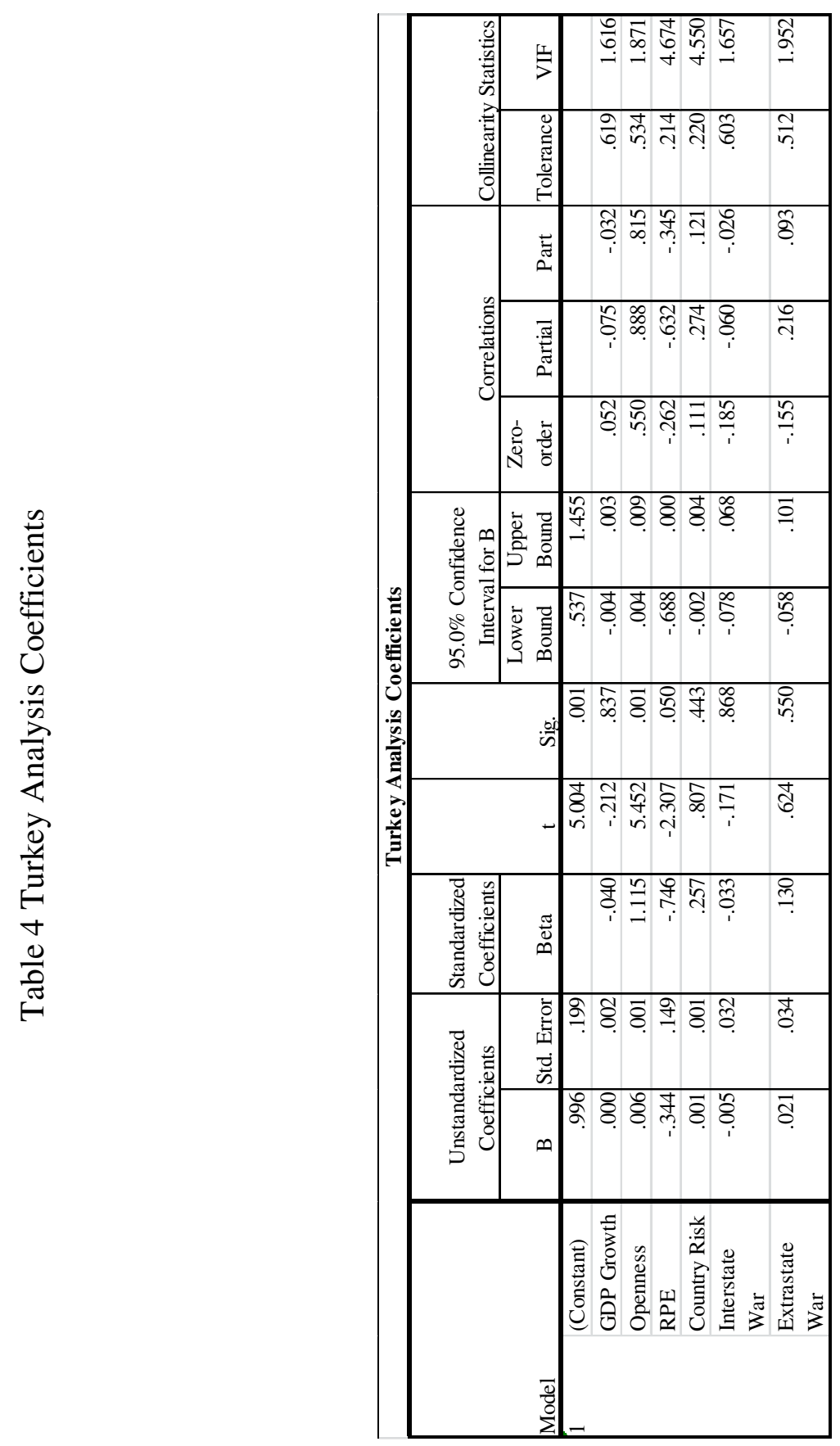


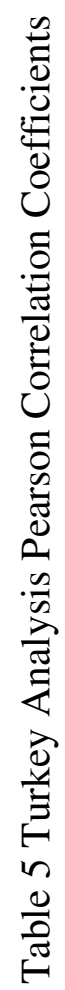

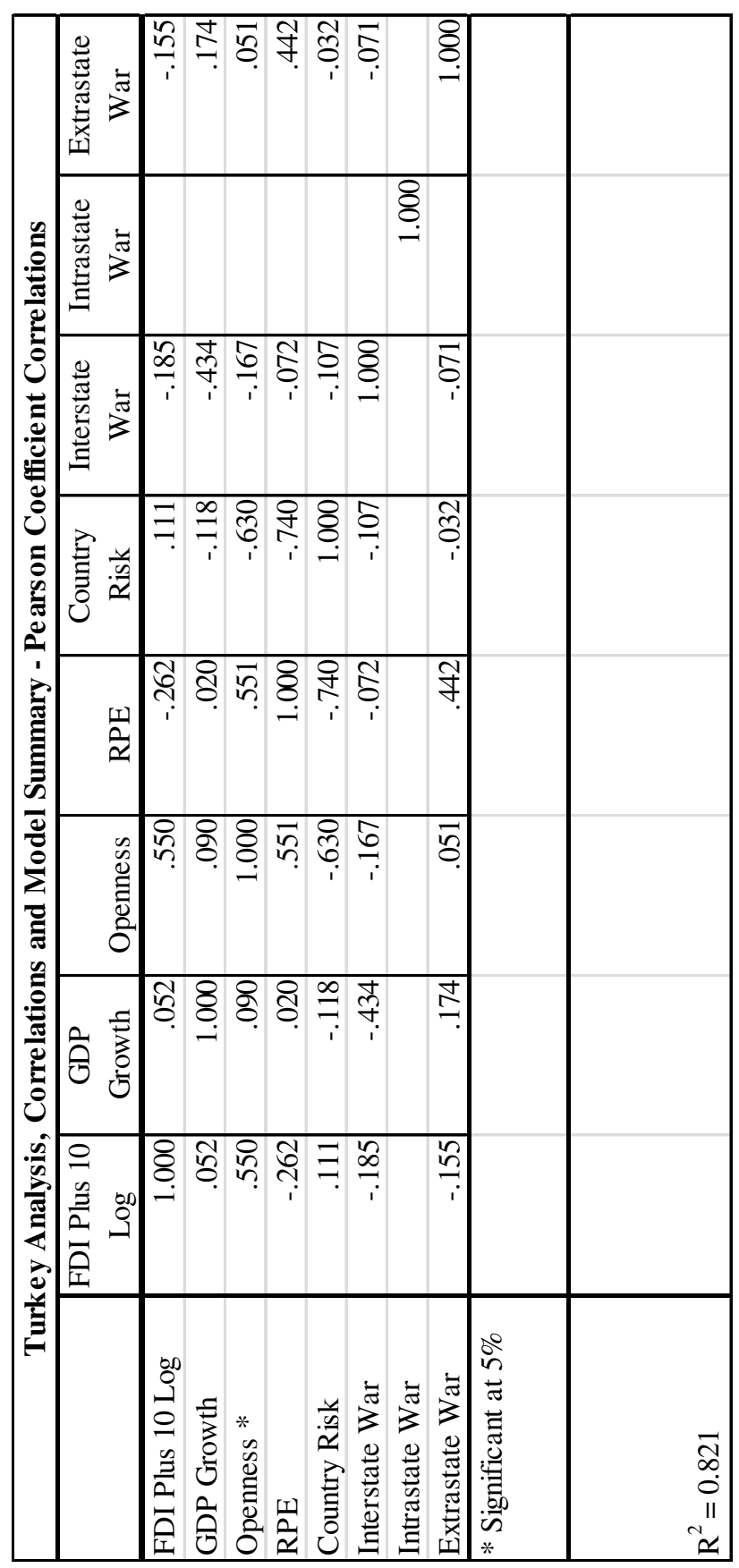


Table 6 Region vs. Turkey Pearson Correlation Coefficients Comparison

\begin{tabular}{|l|c|c|}
\hline & & \\
& Region - DV 1 FDI & $\begin{array}{l}\text { Turkey - DV 2 Net } \\
\text { Change in FDI }\end{array}$ \\
\hline GDP Growth & 0.102 & 0.052 \\
\hline Openness & $0.332 * *$ & $0.55^{*}$ \\
\hline RPE & 0.096 & -0.262 \\
\hline Country Risk & $0.130 *$ & 0.111 \\
\hline Interstate War & -0.069 & -0.185 \\
\hline Intrastate War & 0.010 & \\
\hline Extrastate War & -0.018 & -0.155 \\
\hline$*$ Significant at 5\%; & & \\
$* *$ Significant at 1\% & & \\
& & \\
\hline
\end{tabular}


Table 7 Region vs. Turkey Selected Model Predictors Comparison

\begin{tabular}{|l|c|c|}
\hline & & \\
& Region - DV 1 FDI & $\begin{array}{l}\text { Turkey - DV 2 Net } \\
\text { Change in FDI }\end{array}$ \\
\hline GDP Growth & $\mathrm{X}$ & $\mathrm{X}$ \\
\hline Openness & $\mathrm{X}$ & $\mathrm{X}$ \\
\hline RPE & $\mathrm{X}$ & $\mathrm{X}$ \\
\hline Country Risk & $\mathrm{X}$ & $\mathrm{X}$ \\
\hline Interstate War & $\mathrm{X}$ & $\mathrm{X}$ \\
\hline Intrastate War & $\mathrm{X}$ & na \\
\hline Extrastate War & $\mathrm{X}$ & $\mathrm{X}$ \\
\hline $\mathbf{R}^{2}$ & 0.209 & 0.821 \\
\hline $\begin{array}{l}\text { Theory } \\
\text { Supported? }\end{array}$ & Yes & Yes \\
\hline
\end{tabular}




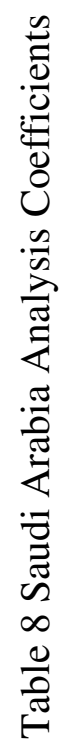

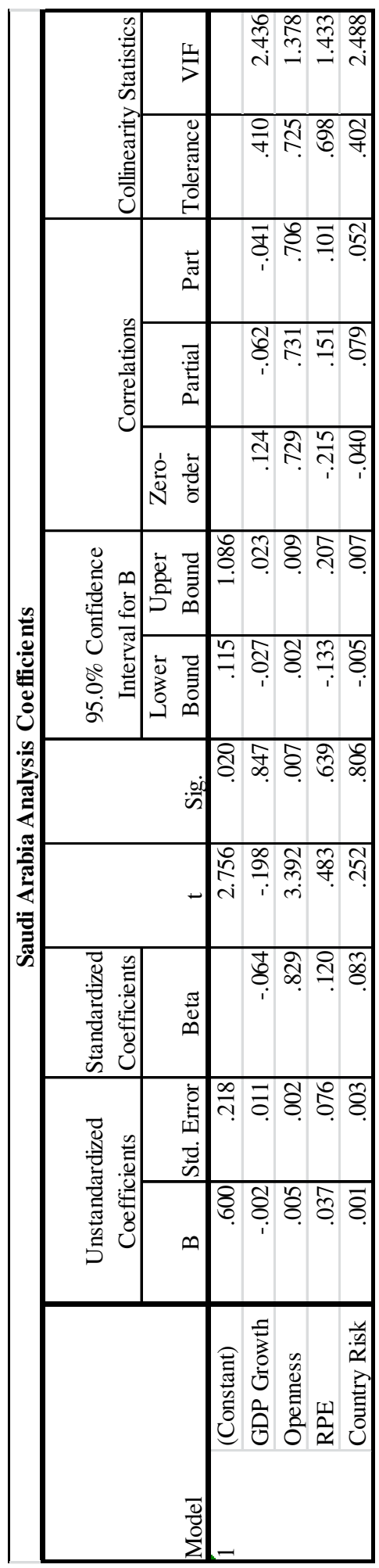

93 


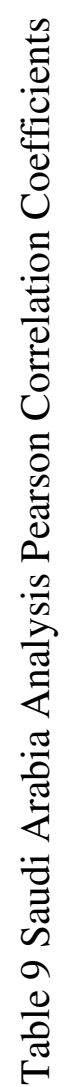

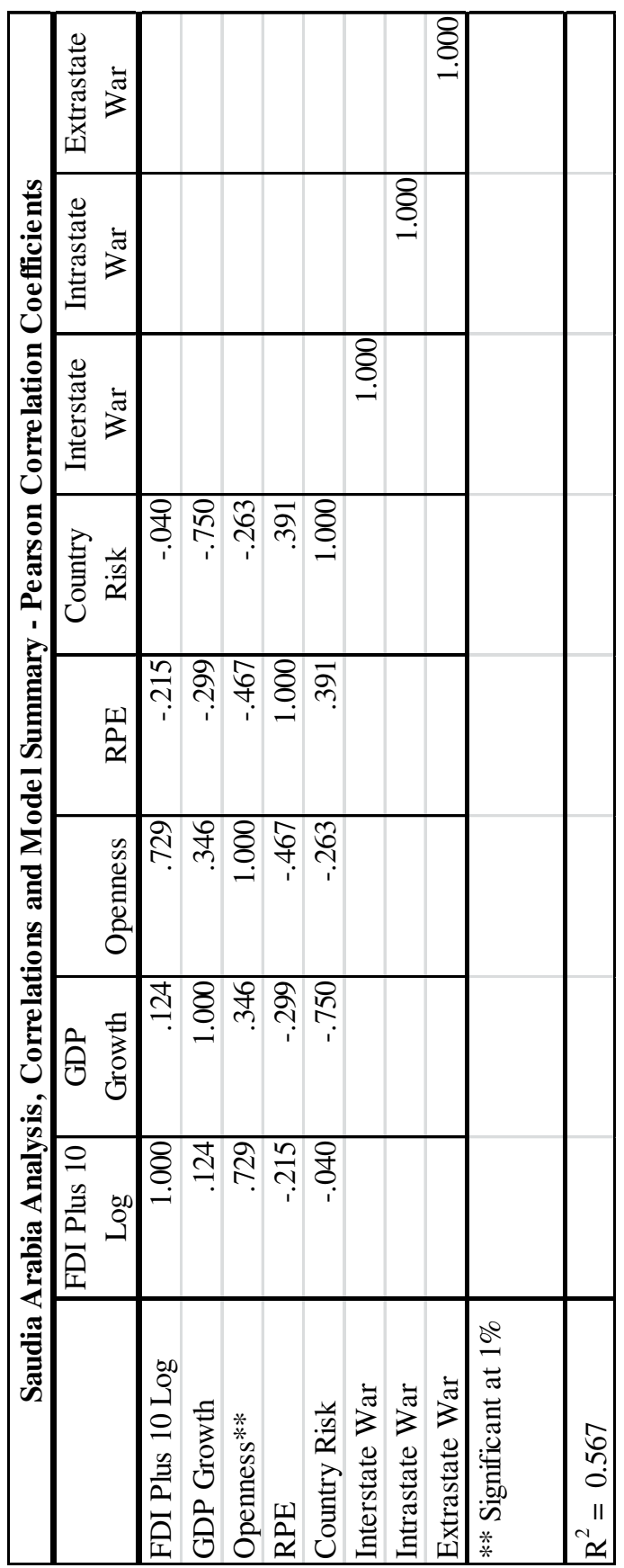


Table 10 Region vs. Saudi Arabia Pearson Correlation Coefficients Comparison

\begin{tabular}{|l|c|c|}
\hline & & \\
& Region - DV 1 FDI & $\begin{array}{l}\text { Saudi Arabia - IV 1 } \\
\text { GDP Growth }\end{array}$ \\
\hline GDP Growth & 0.102 & 0.124 \\
\hline Openness & $0.332 * *$ & $0.729 * *$ \\
\hline RPE & 0.096 & -0.215 \\
\hline Country Risk & $0.130 *$ & -0.04 \\
\hline Interstate War & -0.069 & \\
\hline Intrastate War & 0.010 & \\
\hline Extrastate War & -0.018 & \\
\hline$*$ Significant at 5\%; & & \\
$* *$ Significant at 1\% & & \\
& & \\
\hline
\end{tabular}


Table 11 Region vs. Saudi Arabia Selected Model Predictors Comparison

\begin{tabular}{|l|c|c|}
\hline & & \\
& Region - DV 1 FDI & $\begin{array}{l}\text { Saudi Arabia - IV 1 } \\
\text { GDP Growth }\end{array}$ \\
\hline GDP Growth & $\mathrm{X}$ & $\mathrm{X}$ \\
\hline Openness & $\mathrm{X}$ & $\mathrm{X}$ \\
\hline RPE & $\mathrm{X}$ & $\mathrm{X}$ \\
\hline Country Risk & $\mathrm{X}$ & $\mathrm{X}$ \\
\hline Interstate War & $\mathrm{X}$ & na \\
\hline Intrastate War & $\mathrm{X}$ & na \\
\hline Extrastate War & $\mathrm{X}$ & na \\
\hline R & 0.209 & Yes \\
\hline $\begin{array}{l}\text { Theory } \\
\text { Supported? }\end{array}$ & Yes & \\
\hline
\end{tabular}




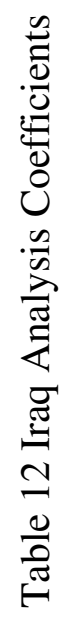

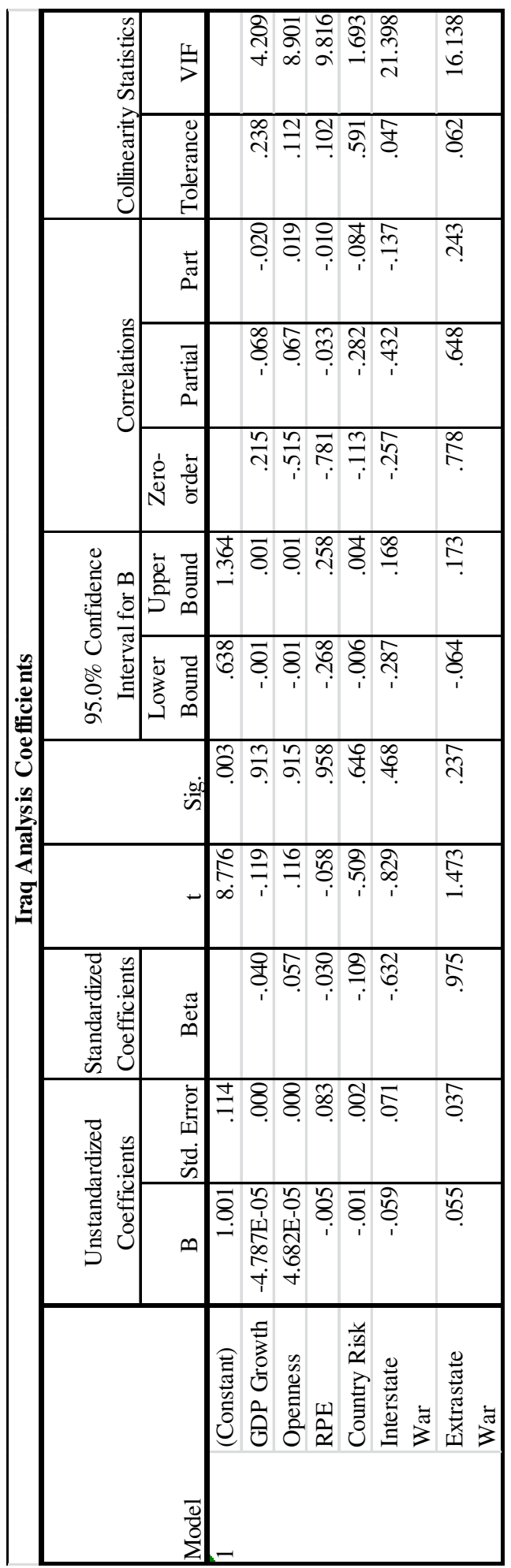


0
0
0
0
0
0
0
0
0
0
0
0
0
0
0
0
0
0
0
0
0
0
0
0
0
0
0
0
0
0
0
0
0
0
0

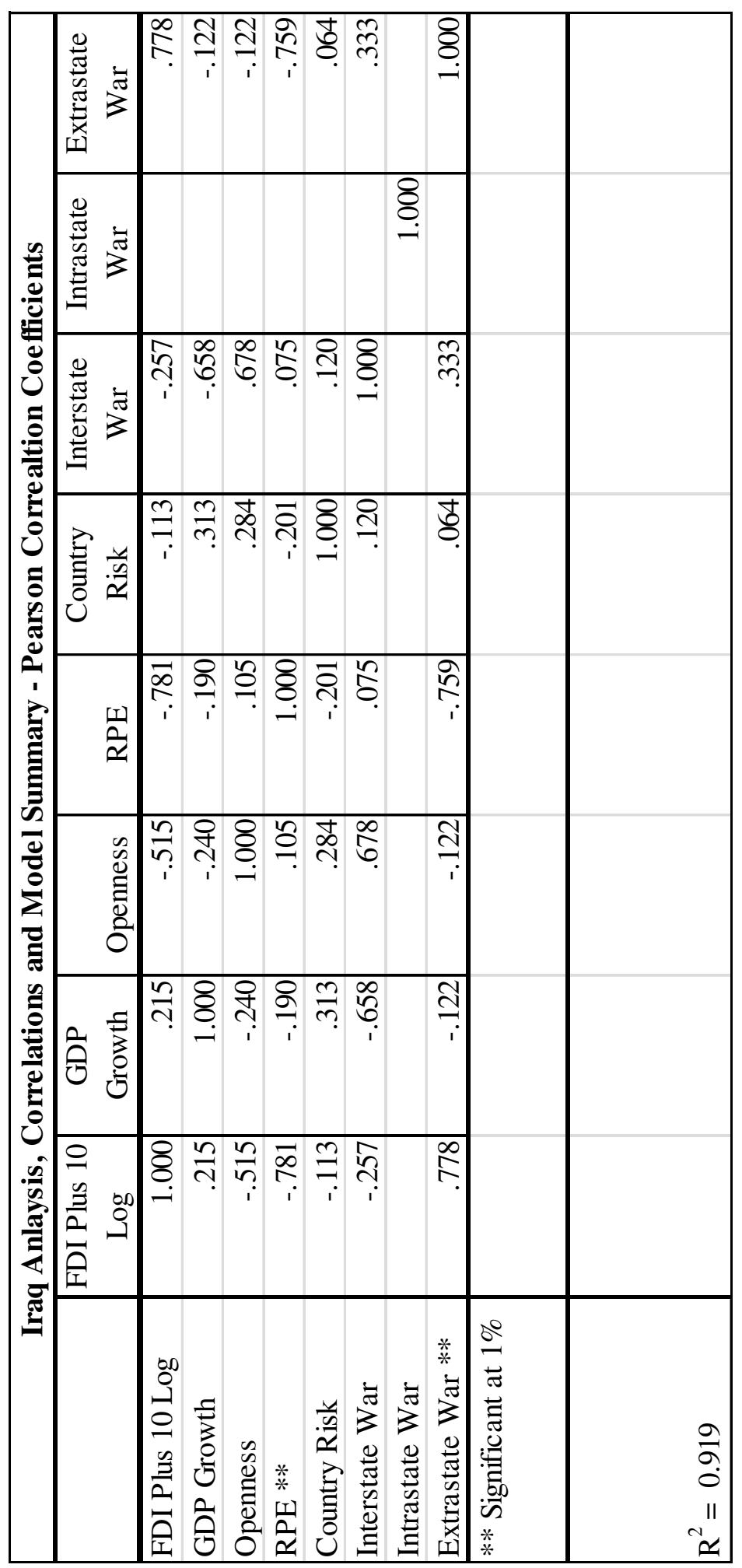


Table 14 Region vs. Iraq Pearson Correlation Coefficients Comparison

\begin{tabular}{|l|c|c|}
\hline & & $\begin{array}{l}\text { Iraq - IV 2, 4, 7 } \\
\text { Openness, } \\
\text { Country Risk High, } \\
\text { Extrastate War }\end{array}$ \\
\hline GDP Growth & 0.102 & 0.215 \\
\hline Openness & $0.332 * *$ & -0.515 \\
\hline RPE & 0.096 & $-.781 * *$ \\
\hline Country Risk & $0.130 *$ & -0.113 \\
\hline Interstate War & -0.069 & -0.257 \\
\hline Intrastate War & 0.010 & \\
\hline Extrastate War & -0.018 & $0.778 * *$ \\
\hline$*$ Significant at 5\%; & & \\
$* *$ Significant at 1\% & & \\
& & \\
& & \\
\hline
\end{tabular}


Table 15 Region vs. Iraq Selected Model Predictors Comparison

\begin{tabular}{|l|c|c|}
\hline & & $\begin{array}{l}\text { Iraq - IV 2, 4, 7 } \\
\text { Openness, } \\
\text { Country Risk High, } \\
\text { Extrastate War }\end{array}$ \\
\hline RDegion - DV 1 FDI & $\mathrm{X}$ & $\mathrm{X}$ \\
\hline Openness & $\mathrm{X}$ & $\mathrm{X}$ \\
\hline RPE & $\mathrm{X}$ & $\mathrm{X}$ \\
\hline Country Risk & $\mathrm{X}$ & $\mathrm{X}$ \\
\hline Interstate War & $\mathrm{X}$ & $\mathrm{X}$ \\
\hline Intrastate War & $\mathrm{X}$ & $\mathrm{X}$ \\
\hline Extrastate War & $\mathrm{X}$ & 0.919 \\
\hline R & 0.209 & Yes \\
\hline $\begin{array}{l}\text { Theory } \\
\text { Supported? }\end{array}$ & $\mathrm{Yes}$ & \\
\hline
\end{tabular}


0
0
0
0
0
0
0
0
0
$\frac{0}{0}$
0
0
0
$\frac{0}{0}$
0
0
0
0
0
0

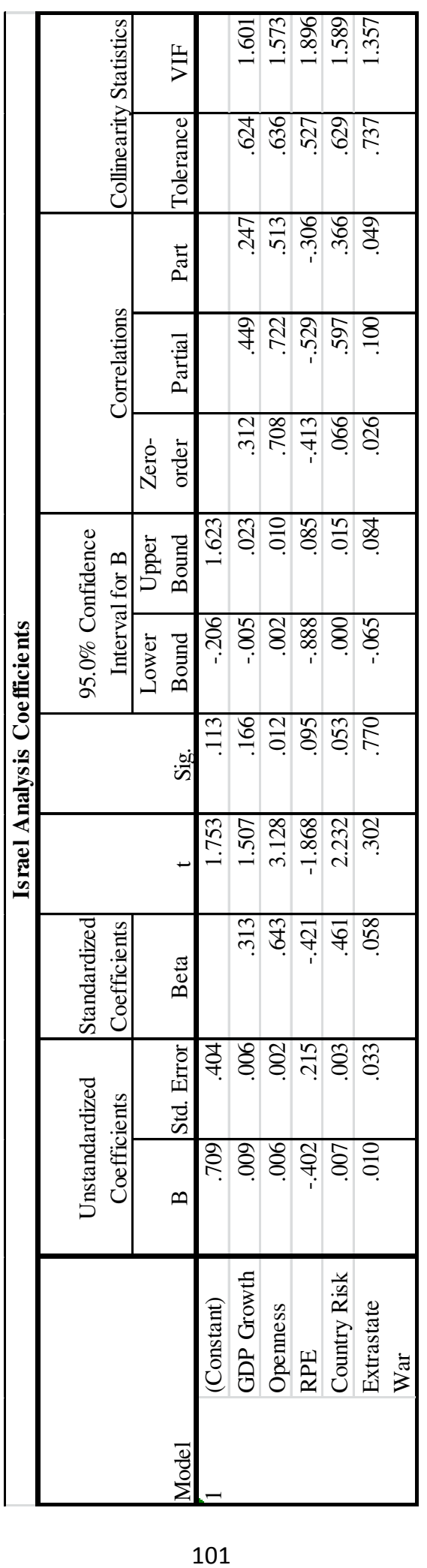


0
0
0
0
0
0
0
0
0
0
0
0
0
0
0
00
0
0
0
0
0
0
0
0
0
0
0
0
0
0
0
0
0

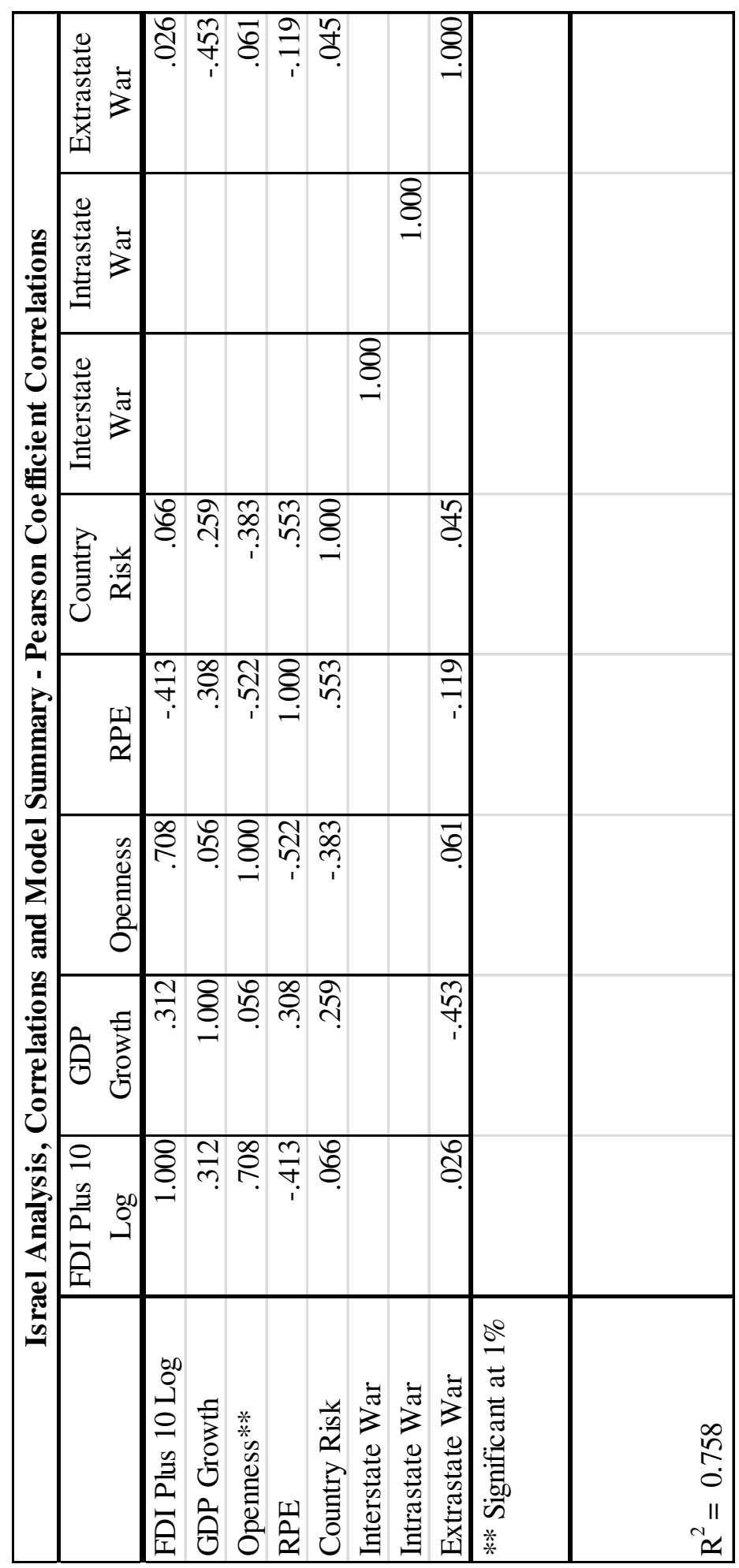


Table 18 Region vs. Israel Pearson Correlation Coefficients Comparison

\begin{tabular}{|l|c|c|}
\hline & & \\
& Region - DV 1 FDI & Israel - IV 3 RPE \\
\hline GDP Growth & 0.102 & 0.312 \\
\hline Openness & $0.332 * *$ & $0.708^{* *}$ \\
\hline RPE & 0.096 & -0.413 \\
\hline Country Risk & $0.130 *$ & 0.066 \\
\hline Interstate War & -0.069 & \\
\hline Intrastate War & 0.010 & \\
\hline Extrastate War & -0.018 & 0.026 \\
\hline * Significant at 5\%; & & \\
** Significant at $1 \%$ & & \\
& & \\
\hline
\end{tabular}


Table 19 Region vs. Israel Selected Model Predictors Comparison

\begin{tabular}{|l|c|c|}
\hline & & \\
& & \\
& Region - DV 1 FDI & Israel - IV 3 RPE \\
\hline GDP Growth & $\mathrm{X}$ & $\mathrm{X}$ \\
\hline Openness & $\mathrm{X}$ & $\mathrm{X}$ \\
\hline RPE & $\mathrm{X}$ & $\mathrm{X}$ \\
\hline Country Risk & $\mathrm{X}$ & $\mathrm{X}$ \\
\hline Interstate War & $\mathrm{X}$ & $\mathrm{na}$ \\
\hline Intrastate War & $\mathrm{X}$ & $\mathrm{na}$ \\
\hline Extrastate War & $\mathrm{X}$ & $\mathrm{X}$ \\
\hline R & 0.209 & Yes \\
\hline $\begin{array}{l}\text { Theory } \\
\text { Supported? }\end{array}$ & $\mathrm{Yes}$ & \\
\hline
\end{tabular}


0
0
0
0
0
0
0
0
0
0
0
0
0
0
0
0
0
0
0
0
0
0
0
0
0
0
0
0
0

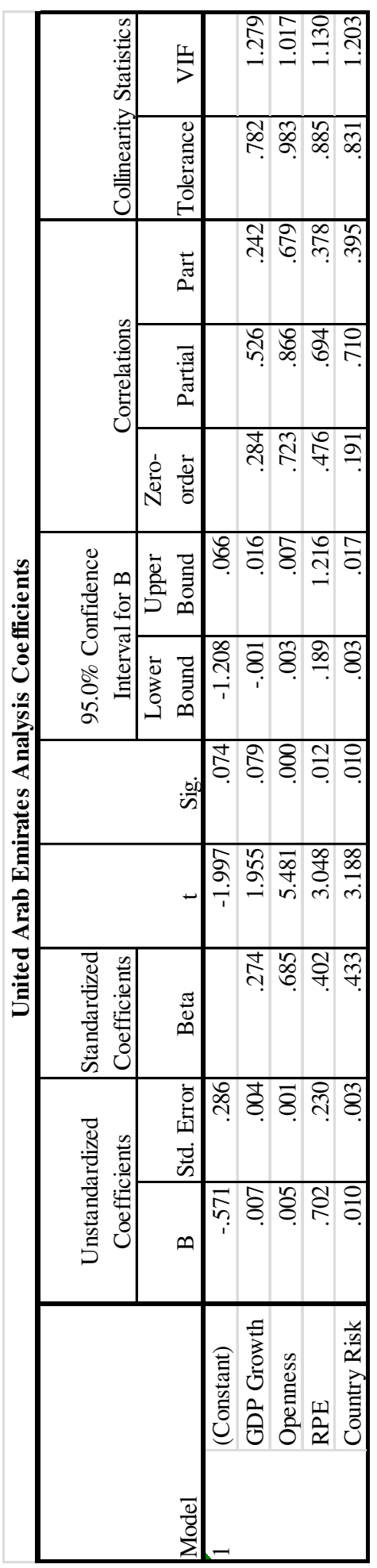

105 


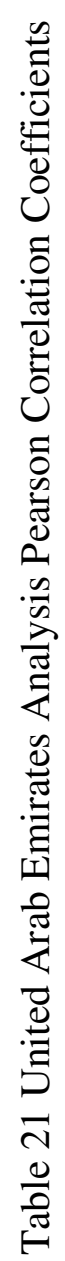

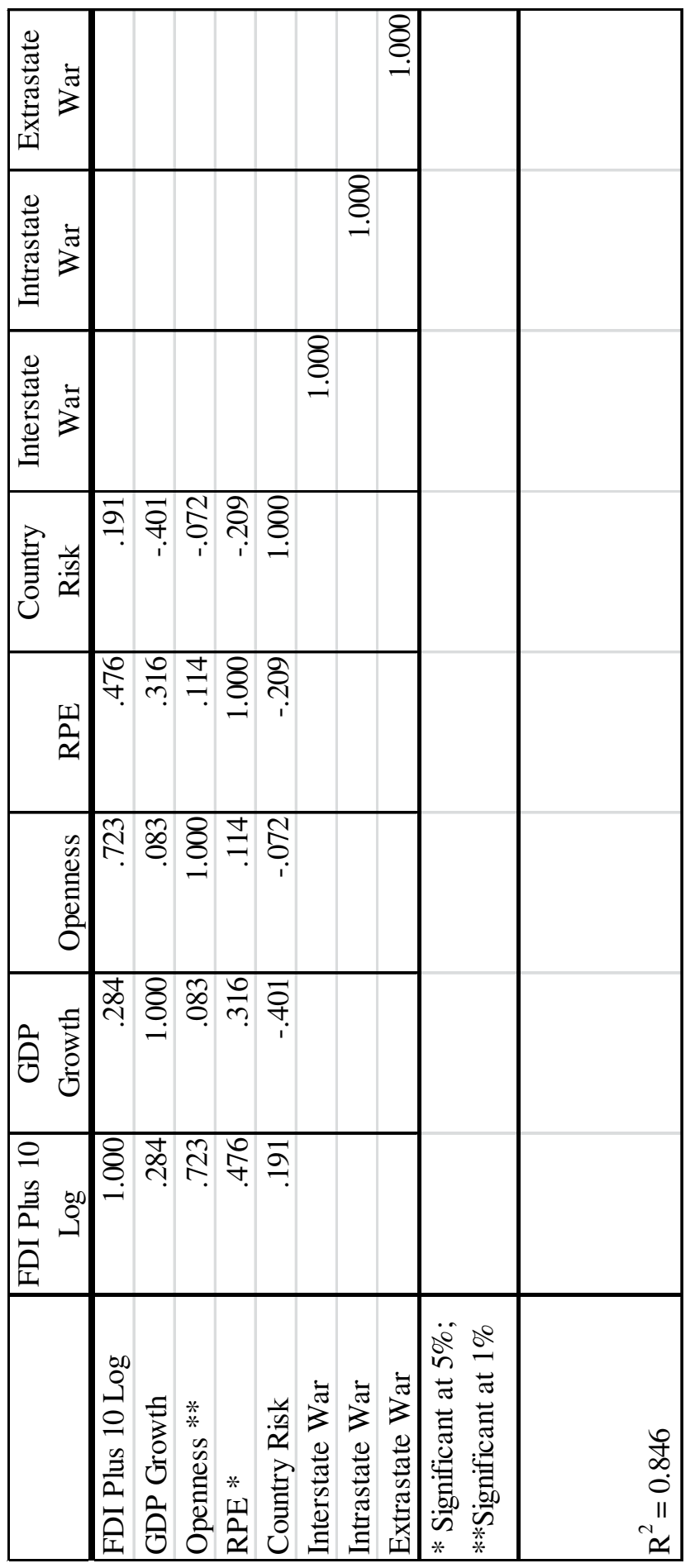


Table 22 Region vs. United Arab Emirates Pearson Correlation Coefficients Comparison

\begin{tabular}{|l|c|c|}
\hline & & $\begin{array}{l}\text { United Arab } \\
\text { Emirates - IV 4 } \\
\text { Country Risk Low }\end{array}$ \\
\hline GDP Growth & 0.102 & 0.284 \\
\hline Openness & $0.332^{* *}$ & $0.723^{* *}$ \\
\hline RPE & 0.096 & $0.476^{*}$ \\
\hline Country Risk & $0.130^{*}$ & 0.191 \\
\hline Interstate War & -0.069 & \\
\hline Intrastate War & 0.010 & \\
\hline Extrastate War & -0.018 & \\
\hline * Significant at 5\%; \\
** Significant at 1\% & & \\
& & \\
\hline
\end{tabular}


Table 23 Region vs. United Arab Emirates Selected Model Predictors Comparison

\begin{tabular}{|l|c|c|}
\hline & & \\
& Region - DV 1 FDI & $\begin{array}{l}\text { United Arab } \\
\text { Emirates - IV 4 } \\
\text { Country Risk Low }\end{array}$ \\
\hline GDP Growth & $\mathrm{X}$ & $\mathrm{X}$ \\
\hline Openness & $\mathrm{X}$ & $\mathrm{X}$ \\
\hline RPE & $\mathrm{X}$ & $\mathrm{X}$ \\
\hline Country Risk & $\mathrm{X}$ & $\mathrm{X}$ \\
\hline Interstate War & $\mathrm{X}$ & $\mathrm{na}$ \\
\hline Intrastate War & $\mathrm{X}$ & $\mathrm{na}$ \\
\hline Extrastate War & $\mathrm{X}$ & \\
\hline R & & \\
\hline $\begin{array}{l}\text { Theory } \\
\text { Supported? }\end{array}$ & Yes & 0.846 \\
\hline
\end{tabular}




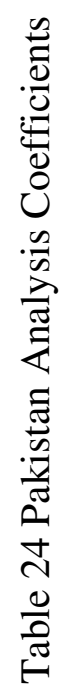

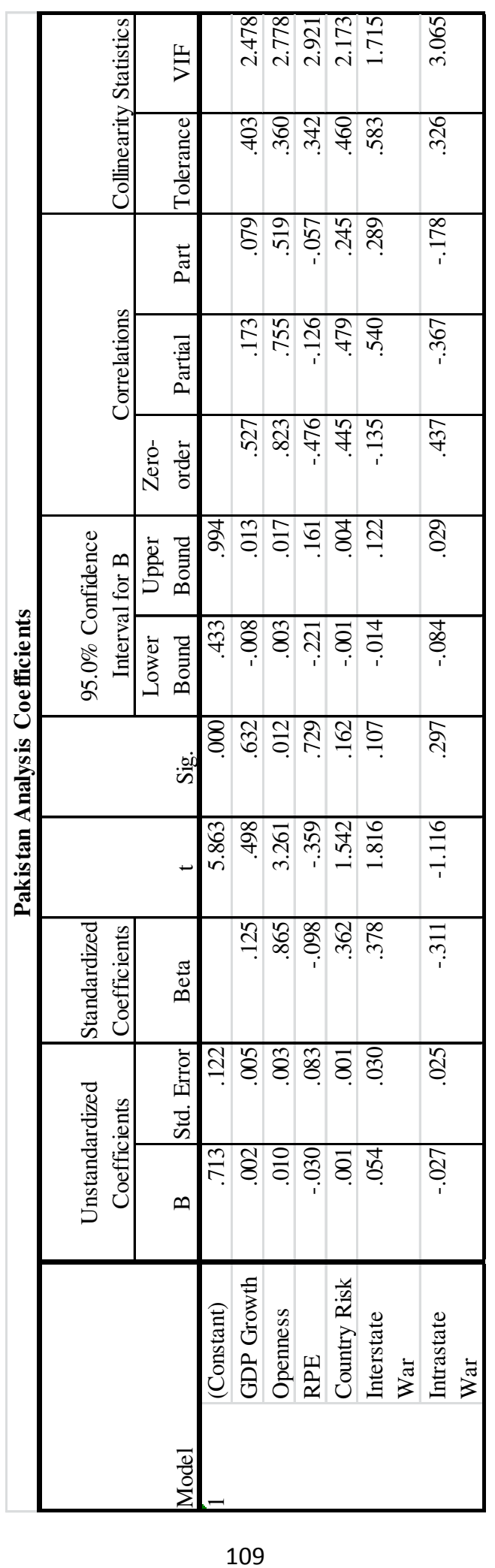




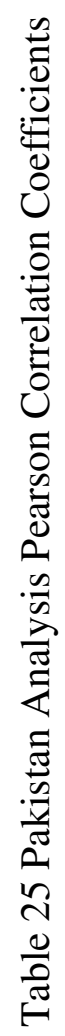

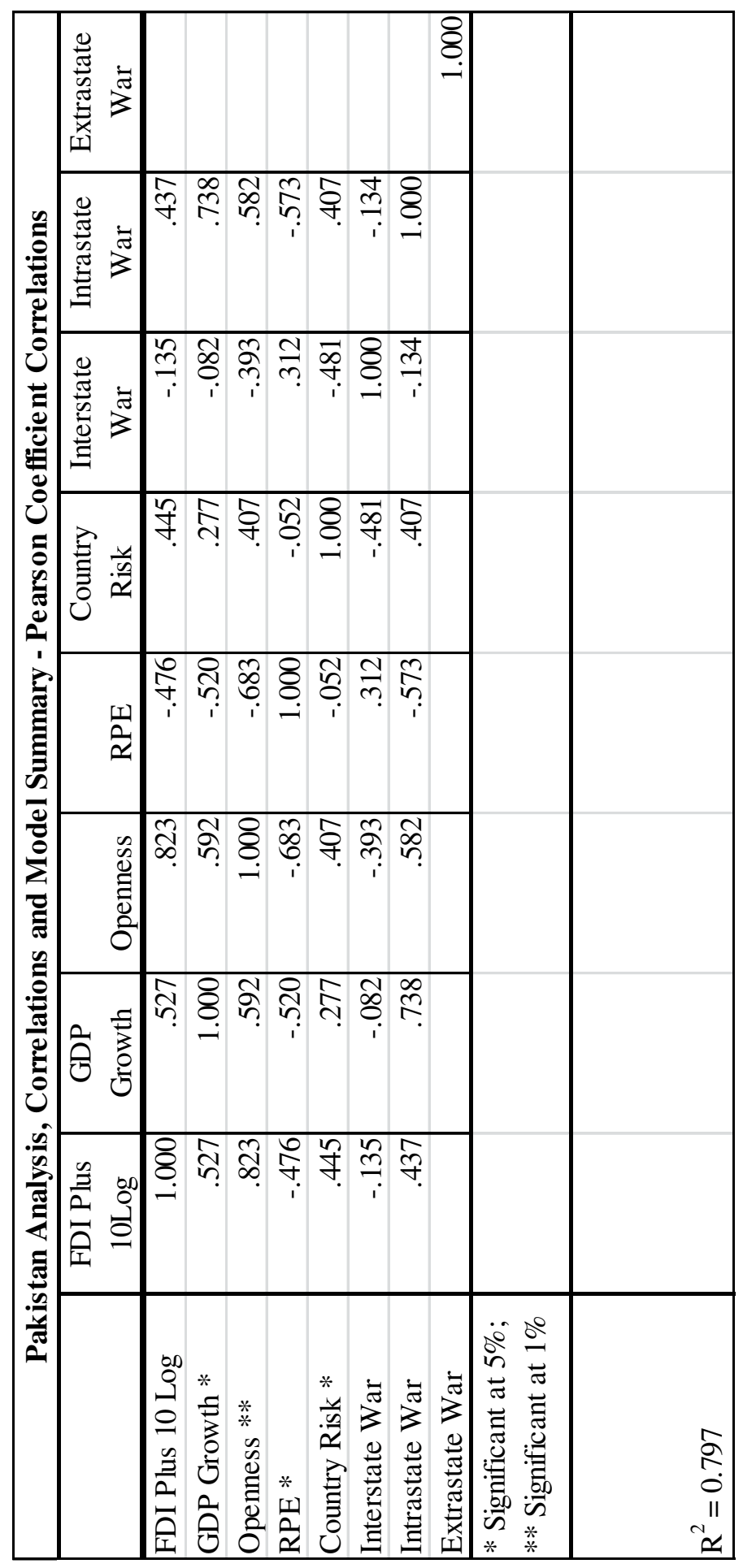


Table 26 Region vs. Pakistan Pearson Correlation Coefficients Comparison

\begin{tabular}{|l|c|c|}
\hline & & \\
& Region - DV 1 FDI & $\begin{array}{l}\text { Pakistan - IV 6 } \\
\text { Intrastate War }\end{array}$ \\
\hline GDP Growth & 0.102 & $0.527^{*}$ \\
\hline Openness & $0.332^{* *}$ & $0.823^{* *}$ \\
\hline RPE & 0.096 & $-0.476^{*}$ \\
\hline Country Risk & $0.130^{*}$ & $0.445^{*}$ \\
\hline Interstate War & -0.069 & -0.135 \\
\hline Intrastate War & 0.010 & 0.437 \\
\hline Extrastate War & -0.018 & \\
\hline * Significant at 5\%; \\
** Significant at 1\% & & \\
& & \\
\hline
\end{tabular}


Table 27 Region vs. Pakistan Selected Model Predictors Comparison

\begin{tabular}{|l|c|c|}
\hline & & \\
& Region - DV 1 FDI & $\begin{array}{l}\text { Pakistan - IV 6 } \\
\text { Intrastate War }\end{array}$ \\
\hline GDP Growth & $\mathrm{X}$ & $\mathrm{X}$ \\
\hline Openness & $\mathrm{X}$ & $\mathrm{X}$ \\
\hline RPE & $\mathrm{X}$ & $\mathrm{X}$ \\
\hline Country Risk & $\mathrm{X}$ & $\mathrm{X}$ \\
\hline Interstate War & $\mathrm{X}$ & $\mathrm{X}$ \\
\hline Intrastate War & $\mathrm{X}$ & \\
\hline Extrastate War & $\mathrm{X}$ & 0.797 \\
\hline R & 0.209 & Yes \\
\hline $\begin{array}{l}\text { Theory } \\
\text { Supported? }\end{array}$ & Yes & \\
\hline
\end{tabular}


0
0
0
0
0
0
0
0
0
0
0
0
0
0
0
0
0
0
0
0
0
0
0
0
0

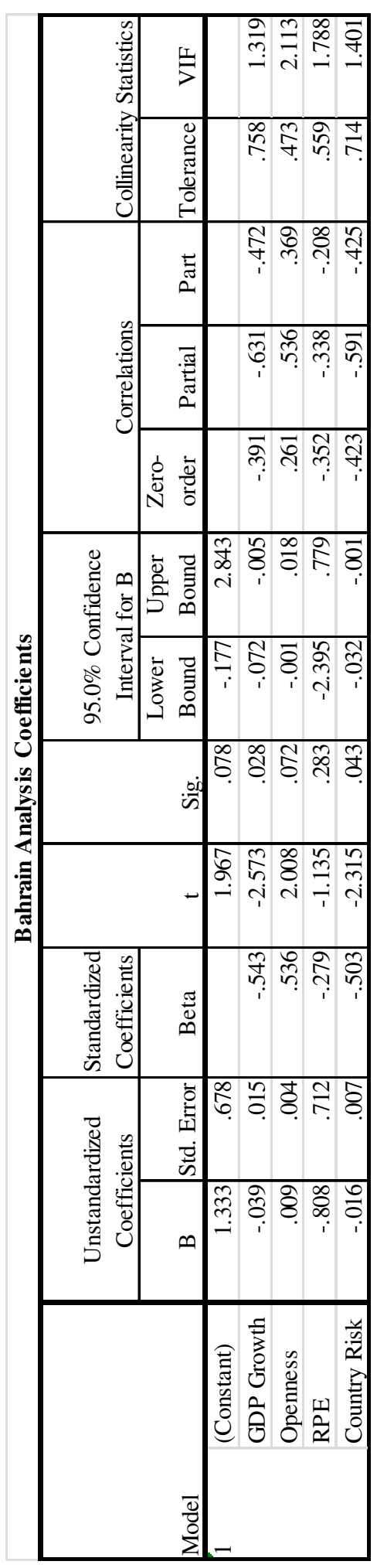




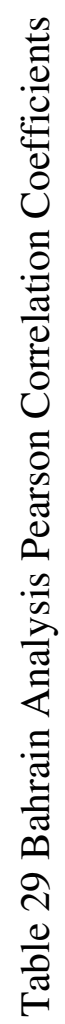

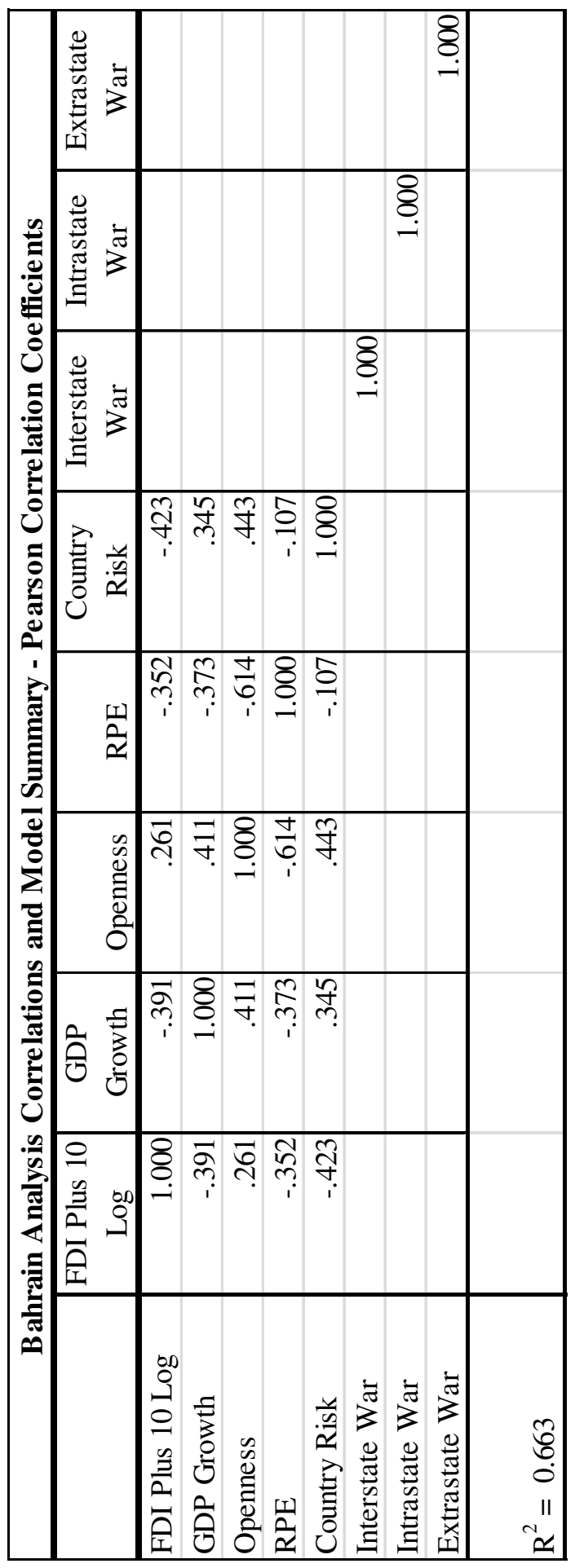


Table 30 Region vs. Bahrain Pearson Correlation Coefficients Comparison

\begin{tabular}{|l|c|l|}
\hline & & $\begin{array}{l}\text { Bahrain - } \\
\text { Petroleum } \\
\text { Dependent } \\
\text { Country }\end{array}$ \\
\hline GDP Growth & 0.102 & -0.391 \\
\hline Openness & $0.332^{* *}$ & 0.261 \\
\hline RPE & 0.096 & -0.352 \\
\hline Country Risk & $0.130 *$ & -0.423 \\
\hline Interstate War & -0.069 & \\
\hline Intrastate War & 0.010 & \\
\hline Extrastate War & -0.018 & \\
\hline$*$ Significant at 5\%; & & \\
** Significant at 1\% & & \\
& & \\
\hline
\end{tabular}


Table 31 Region vs. Bahrain Selected Model Predictors Comparison

\begin{tabular}{|l|c|c|}
\hline & & $\begin{array}{l}\text { Bahrain - } \\
\text { Petroleum } \\
\text { Dependent } \\
\text { Country }\end{array}$ \\
\hline GDP Growth & Region - DV 1 FDI & X \\
\hline Openness & $\mathrm{X}$ & $\mathrm{X}$ \\
\hline RPE & $\mathrm{X}$ & $\mathrm{X}$ \\
\hline Country Risk & $\mathrm{X}$ & $\mathrm{X}$ \\
\hline Interstate War & $\mathrm{X}$ & na \\
\hline Intrastate War & $\mathrm{X}$ & na \\
\hline Extrastate War & $\mathrm{X}$ & na \\
\hline $\mathbf{R}^{2}$ & 0.209 & 0.663 \\
\hline $\begin{array}{l}\text { Theory } \\
\text { Supported? }\end{array}$ & Yes & Yes \\
\hline
\end{tabular}




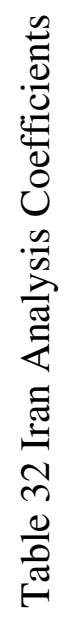

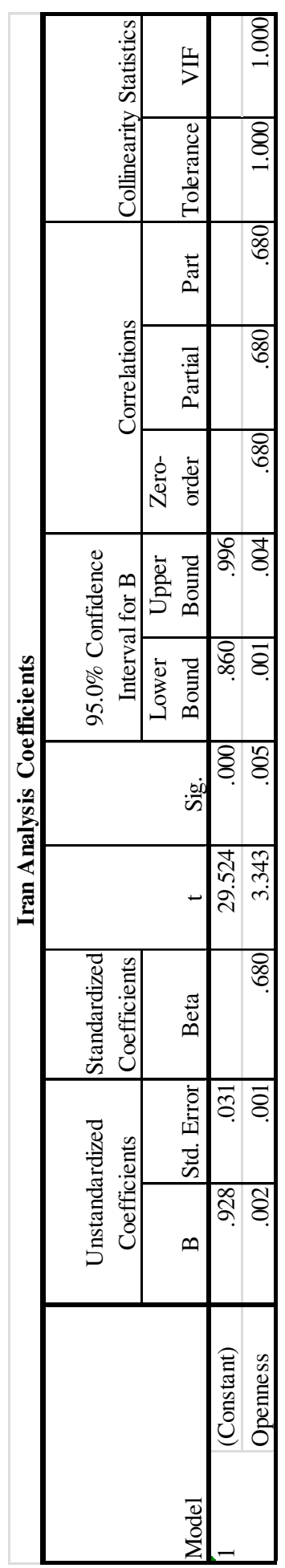

117 


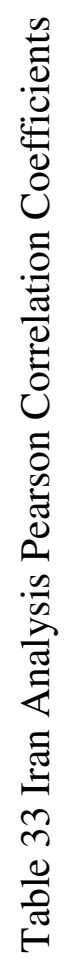

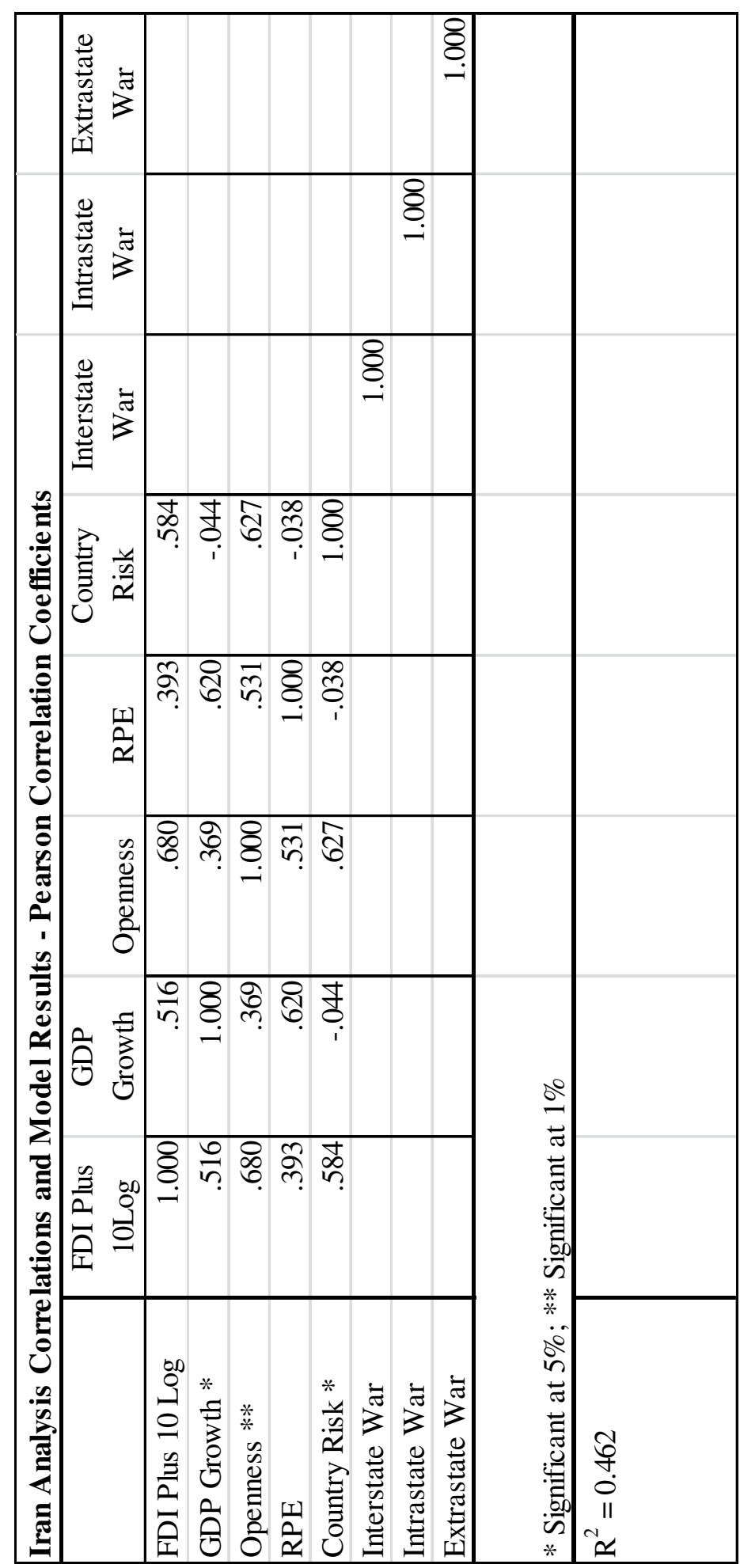


Table 34 Region vs. Iran Pearson Correlation Coefficients Comparison

\begin{tabular}{|l|c|c|}
\hline & & \\
& Region - DV 1 FDI & $\begin{array}{l}\text { Iran - Country of } \\
\text { Interest }\end{array}$ \\
\hline GDP Growth & 0.102 & $0.516^{*}$ \\
\hline Openness & $0.332^{* *}$ & $0.68^{* *}$ \\
\hline RPE & 0.096 & 0.393 \\
\hline Country Risk & $0.130^{*}$ & $0.584^{*}$ \\
\hline Interstate War & -0.069 & \\
\hline Intrastate War & 0.010 & \\
\hline Extrastate War & -0.018 & \\
\hline$*$ Significant at 5\%; \\
** Significant at 1\% & & \\
& & \\
\hline
\end{tabular}


Table 35 Region vs. Iran Selected Model Predictors Comparison

\begin{tabular}{|l|c|c|}
\hline & & \\
& Region - DV 1 FDI & $\begin{array}{l}\text { Iran - Country of } \\
\text { Interest }\end{array}$ \\
\hline GDP Growth & $\mathrm{X}$ & \\
\hline Openness & $\mathrm{X}$ & $\mathrm{X}$ \\
\hline RPE & $\mathrm{X}$ & \\
\hline Country Risk & $\mathrm{X}$ & na \\
\hline Interstate War & $\mathrm{X}$ & na \\
\hline Intrastate War & $\mathrm{X}$ & na \\
\hline Extrastate War & $\mathrm{X}$ & 0.462 \\
\hline R & 0.209 & No \\
\hline $\begin{array}{l}\text { Theory } \\
\text { Supported? }\end{array}$ & Yes & \\
\hline
\end{tabular}




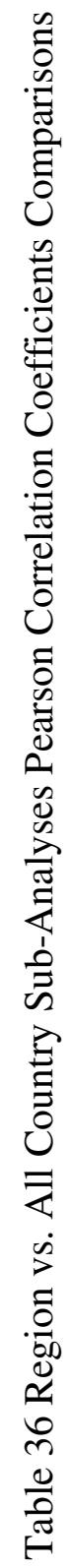

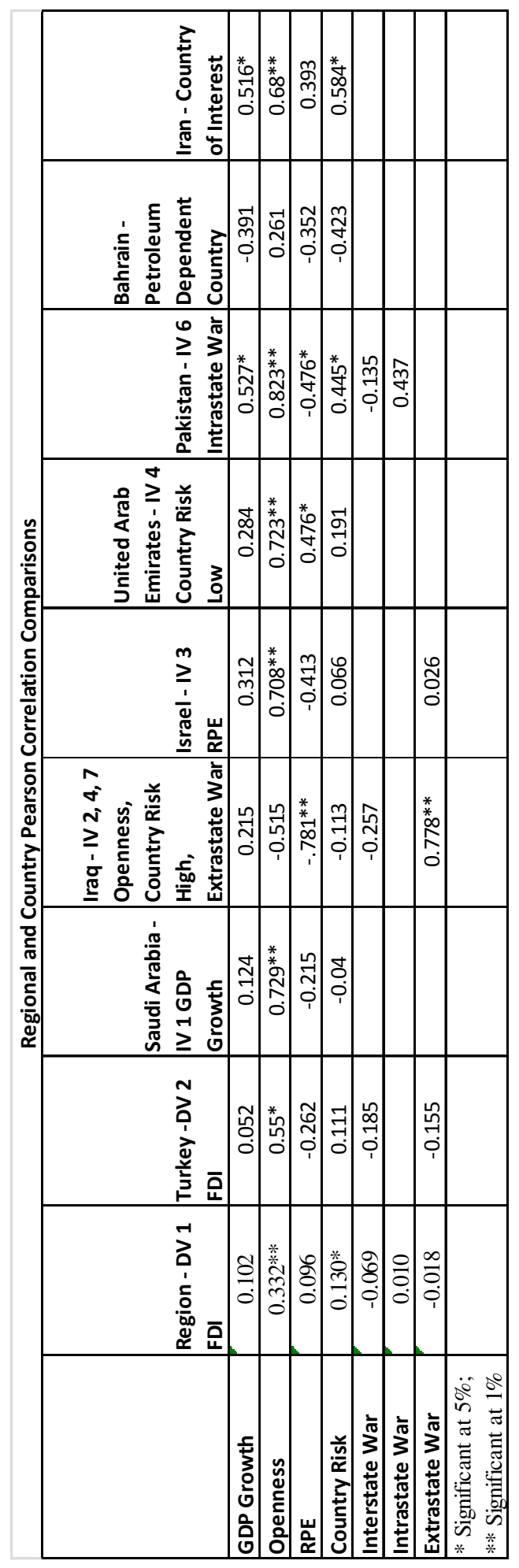

121 


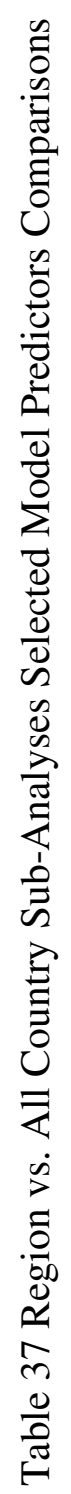

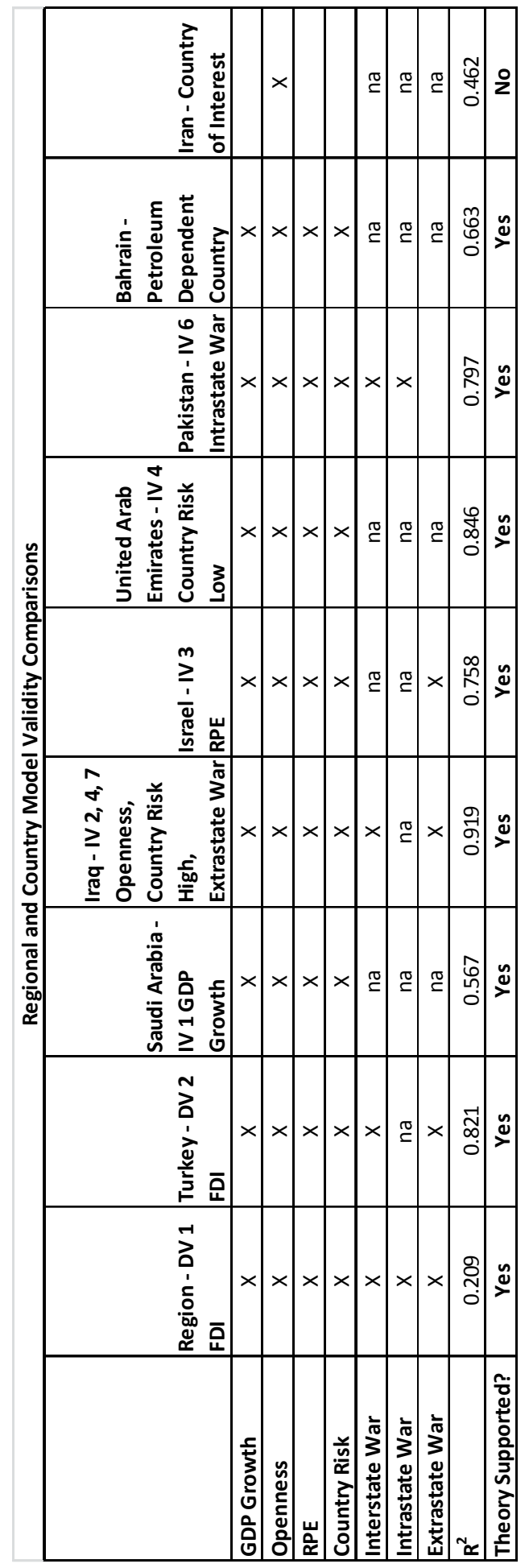

122 


$$
1
$$




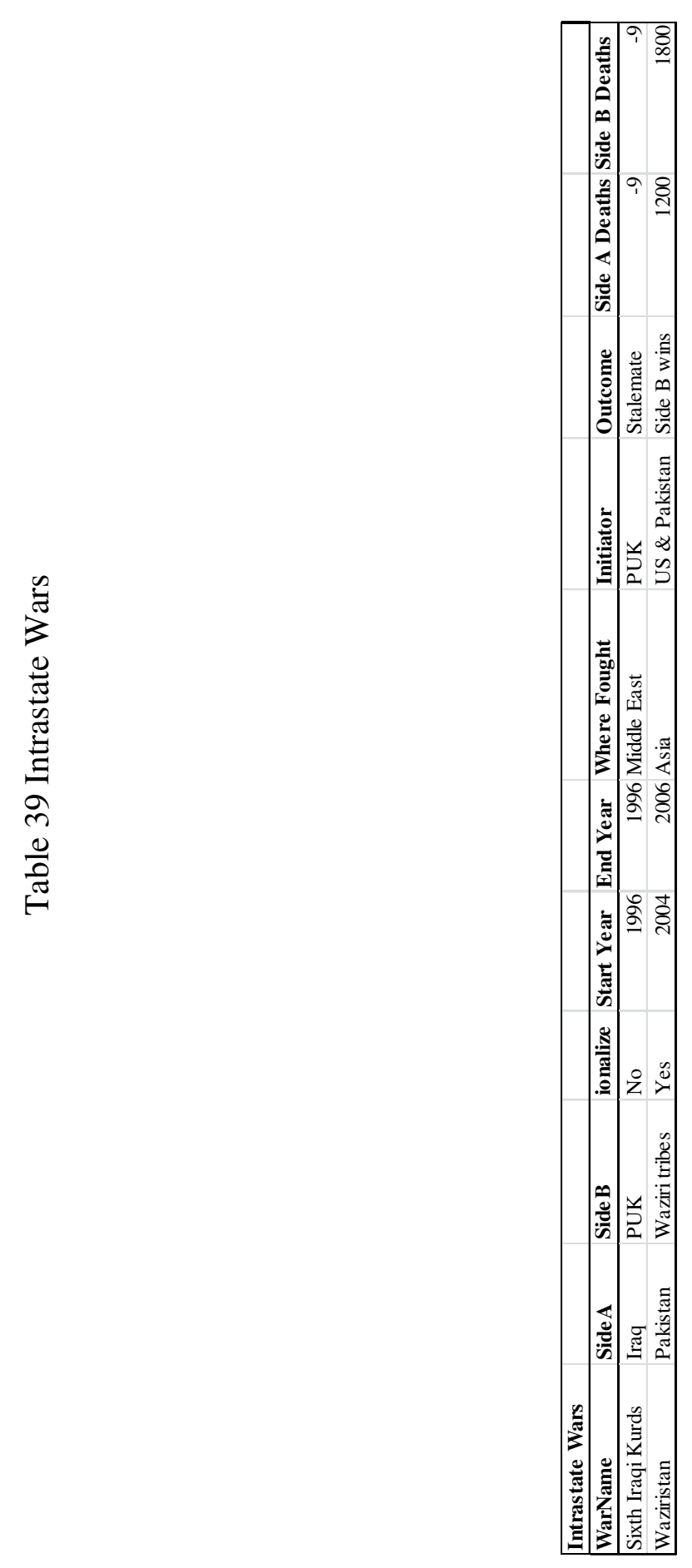

124 


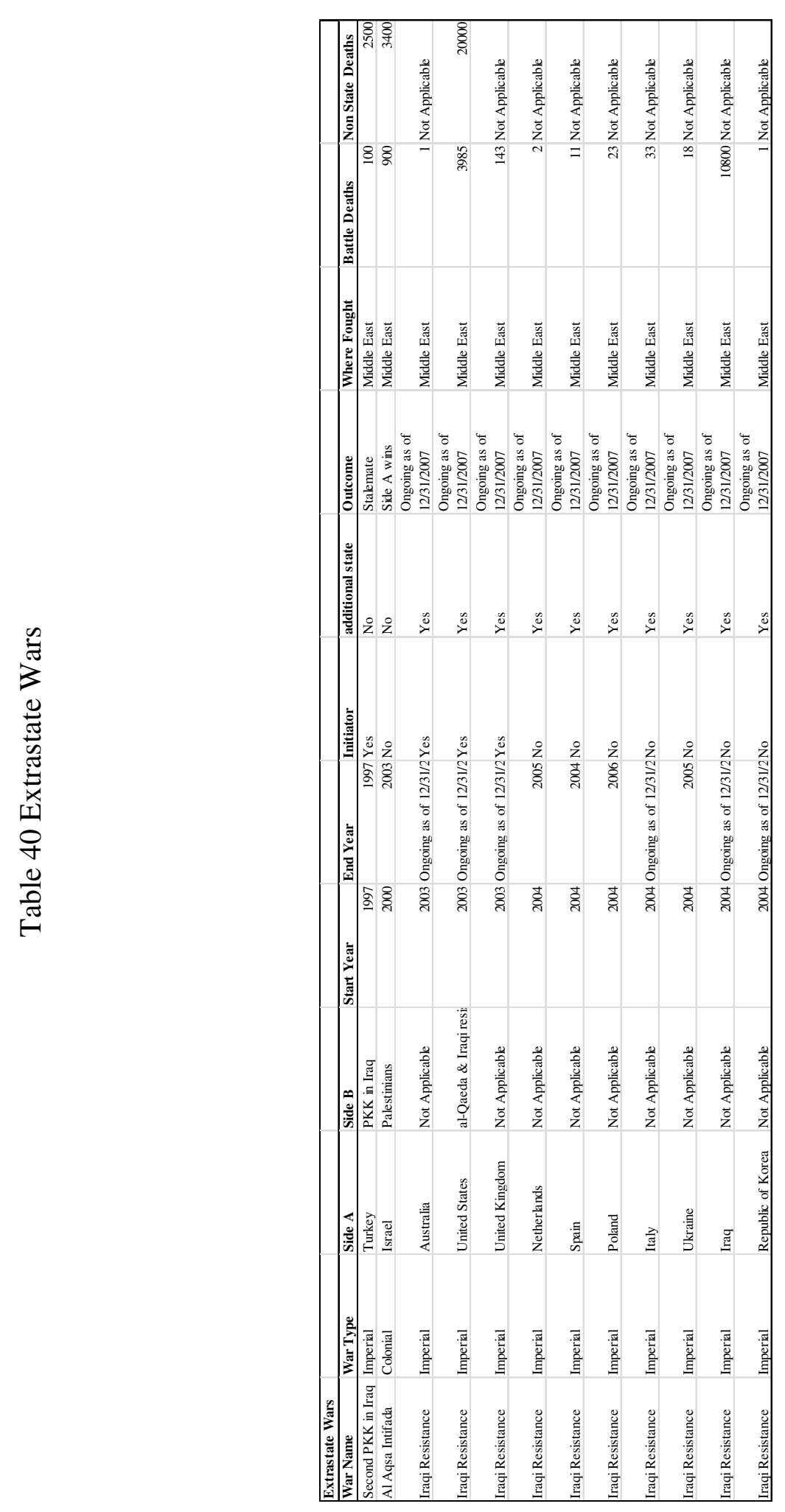




\section{References}

Adji, S.S., Y.S. Ahn, and C.M. Holsey. 1997. "Political Capacity, Macroeconomic Factors, and Capital Flows." In Political Capacity and Economic Behavior, eds. M. Arbetman and M.A.J. Kugler: Basic Books. 127 - 148.

Arbetman-Rabinowitz, Marina, and Kristin Johnson. 2008. Relative Political Capacity: Theory, Model, Data \& Updates. Conference Papers -- International Studies Association: 1.

Arbetman, M., and M.A.J. Kugler. 1997. "Relative Political Capacity: Political Extraction and Political Reach." In Political Capacity and Economic Behavior, eds. M. Arbetman and M.A.J. Kugler: Basic Books. 11 - 45.

Azzimonti, Marina, and Pierre-Daniel G. Sarte. 2007. Barriers to Foreign Direct Investment Under Political Instability. Economic Quarterly (10697225) 93 (3): 287-315.

Biglaiser, Glen, and Karl DeRouen. 2007. Following the Flag: Troop Deployment and U.S. Foreign Direct Investment. International Studies Quarterly 51 (4): 835-854.

Biglaiser, Glen, and Joseph L. Staats. 2010. Do Political Institutions Affect Foreign Direct Investment? A Survey of U.S. Corporations in Latin America. Political Research Quarterly 63 (3): 508-522.

Bussmann, Margit. 2010. Foreign direct investment and militarized international conflict. Journal of Peace Research 47 (2): 143-153.

Butler, K.C., and D. Castelo Joaquin. 1998. A note on political risk and the required return on foreign direct investment. Journal of International Business Studies 29 (3): 599 - 606.

Chakrabarti, Avik. 2001. The Determinants of Foreign Direct Investments: Sensitivity Analyses of Cross-Country Regressions. Kyklos 54 (1).

Coan, Travis G., and Tadeusz Kugler. 2008. The Politics of Foreign Direct Investment: An Interactive Framework. International Interactions 34 (4): 402-422.

"Country Risk Rankings 1993." 1993. Euromoney, March, 92 - 95.

"Country Risk Rankings 1994." 1994. Euromoney, March, 178 - 180.

"Country Risk Rankings 1995." 1995. Euromoney, March, 146 - 150.

"Country Risk Rankings 1996." 1996. Euromoney, March, 160 - 163.

"Country Risk Rankings 1997." 1997. Euromoney March, 164 - 167.

"Country Risk Rankings 1998." 1998. Euromoney September, 203 - 206.

"Country Risk Rankings 1999." 1999. Euromoney March, 97 - 100.

"Country Risk Rankings 2000." 2000. Euromoney March, 106 - 109.

"Country Risk Rankings 2001." 2001. Euromoney March, 106 - 109.

"Country Risk Rankings 2002." 2002. Euromoney September, 210 - 213.

"Country Risk Rankings 2003." 2003. Euromoney, March, 107 - 109.

"Country Risk Rankings 2004." 2004. Euromoney (March).

"Country Risk Rankings 2005." 2005. Euromoney March, 137 - 141.

"Country Risk Rankings 2006." 2006. Euromoney, March, 171 - 174. 
"Country Risk Rankings 2007." 2007. Euromoney, March, 139 - 143.

Dunning, John H. 1998. Globalization and the new geography of foreign direct investment. Oxford Development Studies 26 (1): 47.

Enders, Walter, Adolfo Sachsida, and Todd Sandler. 2006. The Impact of Transnational Terrorism on U.S. Foreign Direct Investment. Political Research Quarterly 59 (4): 517-531.

Enders, Walter, and Todd Sandler. 1996. Terrorism and foreign direct investment in Spain and Greece. Kyklos 49 (3): 331.

Feng, Y., and B. Chen. 1997. "Political Capacity and Private Investment." In Political Capacity and Economic Behavior, eds. M. Arbetman and M.A.J. Kugler: Basic Books. 97 - 108.

Globerman, Steven, and Daniel Shapiro. 2002. Global Foreign Direct Investment Flows: The Role of Governance Infrastructure. World Development 30 (11): 1899.

Groh, Alexander Peter, and Matthias Wich. 2012. Emerging economies' attraction of foreign direct investment. Emerging Markets Review 13 (2): 210-229.

Heston, Alan and Robert Summers and Bettina Aten. 2002. "Penn World Table Version 6.1." In: Center for International Comparisons at the University of Pennsylvania (CICUP).

Jensen, Nathan M., and Daniel J. Young. 2008. A Violent Future? Political Risk Insurance Markets and Violence Forecasts. Journal of Conflict Resolution 52 (4): 527-547.

Jones, D.M., Bremer, S.A., and Singer, J.D. 1996. "Militarized Interstate Disputes, 18161992: Rationale, Coding Rules, and Empirical Patterns.". Conflict Management and Peace Science 15 (2): 163 - 213.

Kaufmann, Daniel, Aart Kraay, and Massimo Mastruzzi. 2011. The Worldwide Governance Indicators: Methodology and Analytical Issues. Hague Journal of the Rule of Law 3 (2): 220-246.

Klasra, Mushtaq. 2011. Foreign direct investment, trade openness and economic growth in pakistan and turkey: an investigation using bounds test. Quality \& Quantity 45 (1): 223-231.

Kugler, J., and R.L. Tammen. 2012. The Performance of Nations. Rowman \& Littlefield Publishers.

Leblang, D. 1997. "Political Capacity and Economic Growth." In Political Capacity and Economic Behavior

eds. M. Arbetman and M.A.J. Kugler: Basic Books. 109 - 125.

Lee, Hoon, and Sara McLaughlin Mitchell. 2012. Foreign Direct Investment and Territorial Disputes. Journal of Conflict Resolution 56 (4): 675-703.

Lemke, D. 2002. Regions of War and Peace. Cambridge University Press.

Liargovas, Panagiotis, and Konstantinos Skandalis. 2012. Foreign Direct Investment and Trade Openness: The Case of Developing Economies. Social Indicators Research 106 (2): 323-331.

Lipsey, Richard G. and Chrystal, K. Alec. 2007. Economics. 11 ed. Oxford; New York: Oxford University Press. 
McGowan Jr, Carl B., and Susan E. Moeller. 2009. A Model for Making Foreign Direct Investment Decisions Using Real Variables for Political and Economic Risk Analysis. Managing Global Transitions: International Research Journal 7 (1): 27-44.

Morrissey, Oliver, and Manop Udomkerdmongkol. 2012. Governance, Private Investment and Foreign Direct Investment in Developing Countries. World Development 40 (3): 437-445.

Onyeiwu, Steve, and Hemanta Shrestha. 2004. Determinants of Foreign Direct Investment in Africa. Journal of Developing Societies (Sage Publications Inc.) 20 (1/2): 89-106.

Organski, A.F.K. 1958. World politics. Knopf.

Organski, A.F.K., and J. Kugler. 1981. The War Ledger. University of Chicago Press.

Powers, Matthew, and Seung-Whan Choi. 2012. Does transnational terrorism reduce foreign direct investment? Business-related versus non-business-related terrorism. Journal of Peace Research 49 (3): 407-422.

Sarkees, Meredith Reid and Frank Wayman. 2010. Resort to War: 1816 - 2007. CQ Press.

Savin, N.E. and K.J. White. 1977. The Durbin-Watson test for serial correlatin with extreme sample sizes or many regressors. Econometrica (45): 1989-1996.

Tammen, R.L. 2000. Power transitions: strategies for the 21 st century. Chatham House Publishers.

Yesilada, Birol. 2012. "Performance of Governments Dataset." In, ed. Birol Yesilada. 